\author{
UNIVERSIDADE DE SÃO PAULO \\ FACULDADE DE EDUCAÇÃO \\ EDUCAÇÃO, LINGUAGEM E PSICOLOGIA
}

SANDRA BRAGA FREIRE

A ÚLTIMA CAVALEIRA DO APOCALIPSE: UM ENREDO

CAÓTICO DO ENSINO DE FILOSOFIA DA ESCOLA PÚBLICA

DO ESTADO DE SÃO PAULO NO ENSINO MÉDIO

São Paulo

2021 
SANDRA BRAGA FREIRE

\section{A ÚLTIMA CAVALEIRA DO APOCALIPSE: UM ENREDO CAÓTICO DO ENSINO DE FILOSOFIA DA ESCOLA PÚBLICA DO ESTADO DE SÃO PAULO NO ENSINO MÉDIO}

Tese apresentada à Banca Examinadora da Faculdade de Educação da Universidade de São Paulo, como exigência parcial para obtenção do título de doutora em Educação Área de Concentração: Educação, Linguagem e Psicologia Orientadora: Profa. Dra. Maria Eliza Mattosinho Bernardes 
AUTORIZO A REPRODUÇÃO E DIVULGAÇÃO TOTAL OU PARCIAL DESTE TRABALHO, POR QUALQUER MEIO CONVENCIONAL OU ELETRÔNICO, PARA FINS DE ESTUDO E PESQUISA, DESDE QUE CITADA A FONTE.

Catalogação da Publicação

Ficha elaborada pelo Sistema de Geração Automática a partir de dados fornecidos pelo(a) autor(a)Bibliotecária da FE/USP: Nicolly Soares Leite - CRB-8/8204

BF86ú Braga Freire, Sandra caótico do ensino de Filosofia da escola pública do Estado de São Paulo no Ensino Médio. / Sandra Braga Freire; orientador Profa. Dra. Maria Eliza Mattosinho Bernardes. -- São Paulo, 2021. $176 \mathrm{p}$.

Tese (Doutorado - Programa de Pós-Graduação Educação, Linguagem e Psicologia) -- Faculdade de Educação, Universidade de São Paulo, 2021.

1. Psicologia Histórico-Cultural. 2. Ensino de Filosofia. 3. Atividade Pedagógica . I. Mattosinho Bernardes, Profa. Dra. Maria Eliza, orient. II. Título. 
Nome: FREIRE, Sandra Braga

Título: A última cavaleira do apocalipse: um enredo caótico do ensino de Filosofia da escola pública do Estado de São Paulo no Ensino Médio.

Tese apresentada à Banca Examinadora da Faculdade de Educação da Universidade de São Paulo, como exigência parcial para obtenção do título de doutora em Educação Área de Concentração: Educação, Linguagem e Psicologia Orientadora: Profa. Dra. Maria Eliza Mattosinho Bernardes

Aprovado em:

Banca Examinadora

Prof. Dr. Instituição:

Julgamento: Assinatura:

Prof. Dr. Instituição:

Julgamento: Assinatura:

Prof. Dr. Instituição:

Julgamento: Assinatura:

Prof. Dr. Instituição:

Julgamento: Assinatura:

Prof. Dr. Instituição: Julgamento: Assinatura: 
Dedico este trabalho à todas as Sandras que me constituem, à minha mãe que mora conosco, Zilda de Sousa Braga, que é a única que me enxerga como sou em meus sonhos... Também não poderia deixar de dedicar este trampo àquele que me deu 0 sobrenome Freire, José Domingos Freire, popularmente conhecido como meu pai; ao Eduardo Silva Costa, minha Marida, por ser meu fidedigno amigo e grande amor since 2011, ao Morgano, meu Golzinho Comunista e ao Compa Luiz Inácio Lula da Silva, que me ensinou que uma ideia ninguém pode aprisionar. Luto aqui é verbo! 


\section{AGRADECIMENTOS}

O doutorado foi, sem dúvidas, o sonho mais doloroso da minha vida. Ele me conduziu a um universo obnubilante, em que por vezes só a afecção e um mundo lacrimoso sobrepujaram esta professora cavaleira e proletária. Contudo, mais uma vez o conhecimento teórico-filosófico e sua atividade venceram e este sonho não poderia ter se tornado realidade sem os meus companheiros de luta, bravos e bravas aliados deste apocalipse educacional, que se irrompe com a Reforma do Ensino Médio e, evidentemente, irá impactar todos os níveis de ensino.

Por isso, manifesto minha incomensurável gratidão a todos que direta ou indiretamente contribuíram para que esta tese se objetivasse, aos que estiveram presentes ao longo de sua produção, seja pela interlocução real ou no campo das ideias, seja pelo incentivo e apoio ou pelo consolo nas horas de desalento. Destarte, agradeço especialmente:

Aos meus pais, Zilda de Sousa Braga e José Domingos Freire, pela vida, pela afetividade, pelas vivências, por estarem comigo no meu pior e no meu melhor, por me ensinarem a ouvir, a observar, a ponderar mais e a sobrelevar a minha condição, em direção à genericidade humana.

À Profa. Dra. Maria Eliza Mattosinho Bernardes, orientadora desta tese, pela paciência e sensatez, por acreditar em mim quando eu já havia desistido, por me mostrar pela dor e pelo amor que eu poderia, ao fim deste processo caótico e dialético, tornar-me pesquisadora. Sou grata pelas reflexões, pelos desafios, por ter aceitado estar comigo nesta jornada que se iniciou outrora, lá no Mestrado.

À Profa. Dra. Laura Marisa Carnielo Calejón, por ser a grande senhora desatadora de nós subjetivos e acadêmicos desta pesquisa, bem como por ser inspiração profissional e pessoal, por sua coerência teórica, ética e política. Obrigada por me empoderar a partir de seu empoderamento! 
Aos professores que compõem a banca de defesa desta tese, em especial ao Prof. Dr. Guillermo Arias Beatón, que foi grande provocador na arguição do Mestrado, contribuindo teórica e afetivamente para a objetivação de uma práxis pedagógica transformadora; obrigada por me permitir sonhar ser doutora. Às professoras Dra. Eliane Candida Pereira e Dra. Mara Lopes de Castilho, pela leitura atenta, preciosa colaboração, pelo incentivo e pelo exemplo! Vocês são esplendorosas!

Ao Prof. Me. Achilles Delari Junior, um dos mais importantes colocutores desta pesquisa, por revolucionar este trabalho, por ser Profeta Maior asseverando que "quanto mais demora o Apocalipse, mais tarde são julgados os vivos e mortos". Sou grata pelo afetuoso e constante incentivo e pela honra de poder estudar Vigotski com você. Eis-me aqui, Profeta. Que se faça o Apocalipse e que nosso luto seja sempre transformado na força da luta!

Ao Prof. Dr. Francisco Diniz Teixeira, amigo de luta e revisor deste texto, pelo privilégio de tê-lo como leitor crítico...

Aos colegas do Gepespp, por compartilharem ideias, críticas e dilemas teóricos, contribuindo de forma decisiva para meu desenvolvimento intelectual e volitivo. Aos meus mais que queridos companheiros de luta, professores das escolas públicas deste país...

À todos os estudantes que passaram por minha vida docente e que tanto me afetaram e ainda me afetam! 
Podrán cortar todas las flores, pero no podrán detener la primavera.

(NERUDA, Pablo) 


\section{RESUMO}

FREIRE, Sandra Braga. A última cavaleira do apocalipse: um enredo caótico do ensino de Filosofia da escola pública do Estado de São Paulo no Ensino Médio. 2021. 176 f. Tese (Doutorado em Educação) - Faculdade de Educação, Universidade de São Paulo, São Paulo, 2021.

ensino escolar pensado para objetivar uma finalidade específica precisa ter intencionalidade que, no caso da presente pesquisa de doutorado, é promover a apropriação do conhecimento teórico-filosófico, procurando transformar as funções psicológicas superiores, contempladas enquanto unidade interfuncional entre o cognitivo, afetivo e volitivo, a partir do referencial teórico-metodológico oriundo da Psicologia Histórico-Cultural. Considera-se o ensino como desenvolvedor, quando os seus sujeitos possuem os mesmos motivos e necessidades, visando uma finalidade em comum. $O$ objetivo da pesquisa é analisar o processo de superação das contradições do Currículo Escolar do Ensino Médio da Secretaria da Educação do Estado de São Paulo a partir da organização de um ensino que possibilite a constituição da unidade afetivocognitivo-volitivo pela mediação do conhecimento teórico-filosófico na atividade pedagógica e filosófica. $O$ problema de pesquisa se expressa pela questão: quais são as condições necessárias para possibilitar um ensino desenvolvedor, por meio da apropriação do conhecimento teórico no ensino de Filosofia no Ensino Médio de uma escola pública estadual, tendo em vista a integração entre as esferas cognitiva, afetiva e volitiva, feita a partir do que prescreve o Currículo do Estado de São Paulo? Para tanto, realizou-se um estudo de campo com intervenção pedagógica de cunho experimental em todas as turmas do Ensino Médio por meio do componente curricular Filosofia, no ano de 2017, em uma escola estadual pública da área urbana e central do município de Cotia-SP. Os instrumentos para coleta de dados foram o caderno pessoal de registros da professora, cadernos e tarefas dos escolares/estudantes, registros fotográficos, sonoros e videogravados, em que se priorizou para a análise os dados aqueles provenientes de uma única turma, uma $1^{\underline{a}}$ série do Ensino Médio, por causa de suas especificidades e de seus desafios. As categorias de análise emergiram da realidade em movimento, a saber: esquemas conceituais, seminário e café filosófico. Cada categoria, integrada às abstrações substanciais e à unidade de pesquisa, as situações vivenciais, visou identificar as transformações das funções psicológicas dos escolares/estudantes. Os resultados indicam que é possível notar a alteração no desenvolvimento dos escolares/estudantes quando, no processo de integração da atividade pedagógica e da atividade filosófica, a práxis pedagógica é voltada para a objetivação de ações e operações que ultrapassem os aspectos técnicos e se direcionem também para a afetividade, para os interesses e para a volição. Assim, as atividades integradas, ao promoverem a apropriação dos conhecimentos teóricos no desenvolvimento de uma consciência que impacte para além da esfera cognoscitiva, e se valha da afetividade, da volição e das vivências como meios transformadores da cognição em direção à genericidade humana sensível, a fim de perceber as nuances, as disparidades e as contradições da realidade concreta, pode (re)qualificar a forma como os estudantes veem e incorporam os 
conceitos e categorias mediadoras das relações, não apenas na escola, mas, sobretudo para além de seus muros.

Palavras-chave: Psicologia Histórico-Cultural, Ensino de Filosofia, Atividade Pedagógica 
FREIRE, Sandra Braga. The Last Knight of the Apocalypse: a chaotic plot of the High School Philosophy teaching in the public school in the State of São Paulo. 2021. 176 p. Thesis (Doctorate in Education) - Faculty of Education, University of São Paulo, São Paulo, 2021

School teaching developed for a specific purpose needs an intention, as for this doctoral research, of promoting the appropriation of theoretical-philosophical knowledge, seeking to transform higher psychological functions from such framework derived from Historical-Cultural Psychology, contemplated as an interfunctional unit between the cognitive, affective and volitional form. Teaching is considered as a developer, when its subjects involved in the process have the same motives and needs aiming at a common purpose. The objective of the research is to analyze how to overcome contradictions in the High School Curriculum of the São Paulo State Department of Education through an organization of teaching that enables the constitution of the affective-cognitivevolitive unit, with a deep thought on theoretical-philosophical knowledge in pedagogical and philosophical activity. The research question is expressed by which are the necessary conditions to enable a developer education through the appropriation of theoretical knowledge in the teaching of Philosophy in High School of a state public school, if this could be made with integration between the cognitive, affective and volitional spheres, based on what the Curriculum of the State of São Paulo prescribes. Therefore, a field study was carried out with an experimental pedagogical intervention in all high school classes with the Philosophy curricular component, in a public state school in the central area of the city of Cotia in 2017. The instruments for data collection were the records on the teacher's personal notebook, tasks and notebooks from students, as well as photographic, sound and video recordings, in which data from a single class, a 1st High School grade, were prioritized for analysis because of its specificities and challenges. The categories of analysis emerged from the named moving realities: conceptual schemes, seminars and debates so-called philosophical coffee. Each category, integrated to the substantial abstractions and to the research unit, aimed to identify through the experiential situations the transformations in the psychological functions of the students. The results indicate that it is possible to notice a change in the development of schoolchildren/students when, in the process of integrating the pedagogical and the philosophical activity, the pedagogical praxis is focused on the objectification of actions and operations that go beyond the technical aspects and are also directed by affectivity, interests and volition. Thus, by promoting the appropriation of theoretical knowledge in the development of a consciousness that impacts beyond the cognitive sphere, and uses affectivity, volition and experiences as means of transforming cognition towards sensitive human genericity, integrated activities help on the understanding the nuances, disparities and contradictions of concrete reality, (re)qualifing the way in which students perceive and incorporate the concepts and categories that mediate relationships, not only at school, but above all beyond its walls. 
Keywords: Historical-Cultural Psychology, Philosophy Teaching, Pedagogical Activity 


\section{LISTA DE QUADROS}

Quadro 1. O Ensino da Filosofia no Brasil do Século

p. 27

$\mathrm{XVI}$ até o fim da primeira década do Século 


\section{LISTA DE FIGURAS}

Figura 1. Exemplo de esquema conceitual na lousa

p. 118

Figura 2. Registro de um escolar/estudante 11/4/2017

p. 119

Figura 3. Registro de um escolar/estudante 17/08/2017

p. 124

Figura 4. Registro do estudante

p. 127

Figura 5. Regras para o seminário na lousa

p. 131

Figura 6. Modelo de mensagem com as regras do

p. 134 seminário para ser enviada via WhatsApp

p. 136

Figura 7. Escolares/estudantes produzindo painéis

p. 137

Figura 8. Escolares/estudantes apresentando seminário

com paine

Figura 9. Escolares/estudantes apresentando seminário

p. 138

por meio do power point

Figura 10. Escolares/estudantes debatendo antes do

p. 139 seminário

Figura 11. Execução da Intervenção Didática e Unidade

p. 143 das Situações Vivenciais

Figura 12. Escolares/estudantes em Café Filosófico

p. 146

Figura 13. Escolares/estudantes em Confraternização

p. 148

Filosófica fora dos muros escolares

Figura 14. Escolar/estudante com a professora

p. 150 


\section{SUMÁRIO}

1. INTRODUÇÃO

2. AS CONTRADIÇÕES HISTÓRICAS SOBRE O ENSINO DE FILOSOFIA NO ENSINO MÉDIO

2.1 Os Marcos Legais para o Ensino da Filosofia na Educação Brasileira - LDB, PCN/EM PNE

2.2 O Currículo Paulista, o Ensino da Filosofia e a Reforma do Ensino Médio 34

3. A FILOSOFIA COMO MEIO PARA A FORMAÇÃO DA CONSCIÊNCIA CRÍTICA 50

3.1 A Filosofia Enquanto Componente Curricular na Formação Humana ....53

3.2 A Formação da Consciência Crítica por meio da Atividade Filosófica ....61

3.3 A Atividade Filosófica na Unidade Dialética entre Cognição, Afetividade e Volição .77

4. O MOVIMENTO DE APROPRIAÇÃO DO CONHECIMENTO TEÓRICOFILOSÓFICO NO ENSINO MÉDIO .88

4.1 A Caracterização da Pesquisa . 92

4.2 A Sistematização de um Plano de Ensino que visa se alçar à Atividade Pedagógica 94

4.2.1 A Elaboração do Plano de Ensino .98

4.3 A Atividade Filosófica e a Atividade Pedagógica nas Situações Vivenciais de Ensino: Uma Intervenção Didático-Pedagógica em meio ao Caos do Ensino Paulista 106

4.3.1 Situação Vivencial 1: Esquema conceitual ..... 115

4.3.2 Situação Vivencial 2: Seminário 128

4.3.3 Situação Vivencial 2: O Café Filosófico 140

5. CONSIDERAÇÕES FINAIS 152

REFERÊNCIAS. 162 


\section{INTRODUÇÃO}

O tempo de estudo determinado para uma pesquisa nem sempre se mostra suficiente para dar a tratativa adequada que permita o desenvolvimento e o avanço integral de hipóteses, análises e teses, haja vista que os prazos urgem e demandam que a atividade de investigação seja encerrada em um período incipiente, fato que atravanca o desenvolvimento de um processo que, em suma, deveria possibilitar a apresentação minuciosa da transformação tanto dos sujeitos, quanto da realidade objetiva.

Isso é apontado porque esta pesquisa começa a ser elaborada no ano em que a Reforma do Ensino Médio ganha legitimidade, por meio de uma legislação específica, a Lei 13.415, de 16 de fevereiro de 2017, que alterou a Lei de Diretrizes e Bases da Educação Nacional de 1996 e estabeleceu uma mudança na estrutura do Ensino Médio, e o documento que melhor lhe representa começou a ser incorporado pelas políticas públicas dos Estados, a saber, a Base Nacional Comum Curricular (BNCC). E, por outro lado, a análise dos dados coletados e a elaboração final do texto se emendaram ao período pandêmico da Covid-19, após a qualificação realizada em setembro de 2019, transcorrendo no caos pedagógico de 2020 e 2021, anos em que a Secretaria da Educação do Estado de São Paulo (Seduc-SP) implantou uma série de alterações tanto em seu Currículo próprio quanto na estrutura geral de suas orientações pedagógicas (por ocasião também da incorporação da BNCC, como supracitado). Assim, todos estes eventos impactaram inevitavelmente, não apenas na intervenção didático-pedagógica feita no ano letivo de 2017, mas também na produção textual, no que concerne à interpretação teórica da categoria história que estava e está submersa num enredo de transformações contraditórias, já vividas outrora, e na análise dos dados coletados.

No entanto, se for considerado o que é de fato possível para este espaço, sobretudo, quando se vislumbra a superação de condições dadas por uma prática que não alavanca a expansão da criatividade e a integração entre as mais variadas esferas das funções psicológicas humanas, pode-se asseverar que o estudo e a intervenção realizadas foram profícuas. Afinal de contas, não é possível parar a vida, a realidade concreta, suas demandas, limites, reveses e 
movimentos, e, além disso, o nome acima anuncia o mais-do-mesmo, uma Reforma não transforma, apenas dá uma nova aparência ao velho e antigo sistema educacional que marginaliza a camada mais pauperizada da sociedade por meio de políticas públicas que defendem sua formação tecnicista.

Esta pesquisa advém da necessidade de alargar o exame acerca da realidade concreta do contexto escolar, visando ultrapassar o que é posto e imposto por legislações que vem engessando, desvalorizando, corrompendo e alienando o trabalho docente. A dissertação que antecede esta tese aponta que a apropriação de um determinado referencial teórico e conhecimentos postos como mediadores, assim como a busca pela sobrelevação dessas legislações e de certas políticas públicas, podem impactar, tanto no que concerne aos aspectos objetivos quanto subjetivos, as relações escolares quando se considera, como piparote inicial, uma sistematização em que ações e operações visam a transformação na forma como os sujeitos submersos neste espaço compreendem a escola e os estudos, isto é, a escola é um dos espaços para avanço do proletariado, por meio da formação de uma consciência crítica, que melhor compreenda a sociedade de classes (FREIRE, 2016).

Para isso pondera-se que apenas um ensino adequadamente sistematizado e voltado para este fim pode transformar e impelir os jovens à aprendizagem e ao desenvolvimento, mas para isso o professor deve ter consciência de sua função social e do poder que tem o conhecimento teórico enquanto mediador (BERNARDES, 2012).

A pesquisa do Mestrado, cuja dissertação foi defendida em 2016, afetou profundamente a vida objetiva desta professora-pesquisadora e desta pesquisadora-professora ${ }^{1}$ de tal maneira que a análise acerca da realidade

\footnotetext{
1 A partir da apropriação do conhecimento teórico da Teoria Histórico-Cultural, a professorapesquisadora e a pesquisadora-professora foi (re)construída enquanto profissional humanizada e comprometida com um ensino sistematizado para a provocar a atividade e promover 0 desenvolvimento dos jovens, por meio de ações e operações direcionadas para a objetivação da aprendizagem escolar. É professora-pesquisadora porque no exercício de sua função executa uma pesquisa e é pesquisadora-professora porque esta pesquisa e este estudo alavancaram a transformação de sua consciência do que é ser professora dentro de um sistema que marginaliza quem está no ensino público (FREIRE, 2016, p. 11). No entanto, no decurso desta pesquisa acontece a unidade entre ambas, cessando a diferenciação que outrora existia, haja vista que enquanto sujeito da pesquisa compreende a necessidade da integração entre a professora e a pesquisadora por causa de sua consciência de classe e de sua função social.
} 
escolar e sua atividade ${ }^{2}$ de estudo pessoal passou a compreender de outro modo a constituição multifacetada da escola, das teorias pedagógicas e das políticas públicas, porém esta nova perspectiva e este novo olhar não foi encerrado com o término do prazo daquela pesquisa, ao contrário.

Após o fim do Mestrado esta professora passou pela coordenação nos anos de 2015 e 2016, a convite da equipe gestora da escola pesquisada em 2014, e retornou à sala de aula em 2017 com o desejo de incorporar as experiências apreendidas à sala de aula; daí a mobilização de novas necessidades, parte delas vinculadas a suprir certas lacunas que os prazos não permitiram preencher no Mestrado e outras diagnosticadas na passagem pela coordenação. Assim, o exame crítico da escola e de sua constituição plural, tanto no que concerne às políticas públicas, práticas, leis e teorias, conduziu esta professora a esta tese.

Destarte, esta pesquisa para além de apresentar que a (re)organização de um dado Currículo (SÃO PAULO, 2012), em seus aspectos metodológicos, pode possibilitar a apropriação do conhecimento teórico, quando são considerados os fatores motivacionais, afetivos, subjetivos e volitivos, mostra que a afetividade, os interesses, a volição e as vivências, quando adequadamente orientadas, podem contribuir para a intersecção entre as esferas cognitivas às esferas afetivas.

Nisso a atividade pedagógica, unidade entre a atividade de ensino e a atividade de estudo (BERNARDES, 2012), emerge como categoria necessária para ser integrada à atividade filosófica ${ }^{3}$, unidade cuja necessidade é ascender do pensamento oriundo do senso comum ao concreto pensado, desenvolvendo o pensamento por conceitos na vida objetiva dos escolares, constituindo, assim, importante função de ser 0 instrumento que possibilita organizar e integrar 0 ensino e o estudo, como meios desenvolvedores das funções psicológicas

\footnotetext{
${ }^{2} \mathrm{~A}$ atividade neste contexto refere-se à unidade central da vida do sujeito concreto, que o orienta no mundo dos objetos para a satisfação de necessidades produzidas socialmente (LEONTIEV, 1983).

${ }^{3}$ A atividade filosófica é a unidade dialética cunhada por Freire (2016) em sua dissertação de Mestrado, para representar o movimento de transformação os escolares/estudantes no processo de ascensão do pensamento do senso comum à consciência crítica, do pensamento concreto ao abstrato e deste para o concreto pensado, desenvolvendo o pensamento por conceitos e por que não, direcioná-los a começar a pensar dialeticamente.
} 
superiores dos sujeitos submersos nas relações escolares, conforme será abordado no decurso deste texto.

Por conseguinte, considera-se que a atividade pedagógica expressa um ensino desenvolvedor (DAVIDOV, 1988) quando os seus sujeitos possuem os mesmos motivos e necessidades, o que significa aqui, compreender o espaço escolar como um dos meios para a superação das condições impostas pelo sistema de ensino vigente, advindas das concepções e intenções de uma dada sociedade.

Desta feita, o objetivo geral da pesquisa é analisar o processo de superação das contradições do Currículo Escolar do Ensino Médio da Secretaria da Educação do Estado de São Paulo (Seduc-SP) (SÃO PAULO, 2012) a partir da organização de um ensino que possibilite a constituição da unidade afetivocognitivo-volitivo pela mediação do conhecimento teórico-filosófico na atividade pedagógica e filosófica.

Os objetivos específicos desdobram-se no estudo bibliográfico-conceitual e na análise didático-interventiva. Daí tem-se, quanto à disposição dos capítulos que compõem o corpo teórico desta tese, o primeiro que é intitulado "As contradições históricas sobre o ensino de filosofia no ensino médio", em que é apresentado o estudo acerca da historicidade dos elementos que impactam na prática hodierna do ensino de Filosofia que se pretende desenvolvedor, a saber, um estudo que abarca os marcos legais da Filosofia enquanto componente curricular dos bancos escolares, posto que as legislações afetam diretamente a forma como a Filosofia pode ou não estar presente na sala de aula ou na formação dos professores. E o capítulo seguinte, "A Filosofia como meio para a formação da consciência crítica”, que mostra a Filosofia enquanto necessidade que forma o humano no homem, pois por meio desta (necessidade) é engendrada a atividade filosófica, quando o homem, em termos marxianos, transforma o meio e a si mesmo na apropriação do seu modus operandi, a saber, a passagem do senso comum para a consciência crítica na elaboração da cultura e do conhecimento.

O capítulo que compõe a análise didático-interventiva, por seu turno, é o desdobramento do estudo teórico, a síntese da teoria com a prática, em que uma pesquisa de campo que se dá por meio de uma intervenção didático-pedagógica 
busca deslindar as características mais aparentes em relação às que estão ocultas na realidade escolar.

O capítulo "O movimento de apropriação do conhecimento teóricofilosófico no Ensino Médio" apresenta o foco principal da intervenção didáticopedagógica, impactar o ensino e a aprendizagem de um grupo de escolares ${ }^{4}$ a partir de uma (re)organização curricular, que melhor se adequasse às especificidades daquela realidade escolar que os circundava naquele momento.

A respeito da trajetória da intervenção didático-pedagógica, foi necessária a elaboração de um plano de ensino e de aulas que se propusesse a alavancar o desenvolvimento para além dos aspectos cognitivos dos jovens. É válido salientar neste momento que a pesquisa de campo ocorreu em uma escola pública do Estado de São Paulo, em que no momento da intervenção didáticopedagógica havia um Currículo (SÃO PAULO, 2012) cuja política pública determinava sua execução em sala de aula, mas que, no entanto, este mesmo Currículo nem sempre se mostrava eficiente e/ou contemplava as necessidades dos escolares, circunscritos em um determinado contexto escolar.

Assim, o plano de ensino e de aula considerou como conteúdo o proposto pelo Currículo da Secretaria da Educação do Estado de São Paulo (Seduc-SP) (SÃO PAULO, 2012) e seu principal articulador, a Matriz de Avaliação Processual (SÃO PAULO, 2016), ferramentas didáticas que serviram para colocar o conhecimento teórico-filosófico como mediatizador ${ }^{5}$ da atividade pedagógica e filosófica.

Daí o objeto de pesquisa ser a (re)organização do ensino de Filosofia, com a intenção de promover a transformação no psiquismo dos escolares, de um determinado contexto escolar, e possibilitar meios para a superação do caos

\footnotetext{
${ }^{4}$ Assim como no Mestrado, justifica-se o uso do termo escolar em detrimento do termo aluno, porque as inúmeras teorias pedagógicas desvinculadas da Teoria Histórico-Cultural associam aluno ao sujeito passivo, que precisa ser iluminado para aí então tornar-se capaz de aprender. Em contrapartida, o escolar é aquele que está submerso nas relações escolares, no processo de escolarização; este é um termo utilizado pela Psicologia Histórico-Cultural, por exemplo, na obra de Davidov (1988) e Vigotski (2006). O termo estudante, por sua vez, é atribuído ao sujeito que está em atividade (de estudo) e integra a atividade pedagógica quando mobilizado pelo professor (FREIRE, 2016, p. 11).

${ }^{5} \mathrm{Na}$ Teoria Histórico-Cultural a categoria mediar é de suma importância para mostrar que os fenômenos da realidade objetiva não são espontâneos e imediatos, mas produtos da necessidade e ação humana no decurso da história.
} 
estabelecido pelas políticas públicas que operam de modo contraditório no cerne da estrutura do ensino paulista.

O organizador das ações investigativas, por sua vez, é expresso pela seguinte questão: Quais são as condições necessárias para possibilitar um ensino desenvolvedor, por meio da apropriação do conhecimento teórico no ensino de Filosofia no Ensino Médio de uma escola pública estadual, tendo em vista a integração entre as esferas cognitiva, afetiva e volitiva, feita a partir do que prescreve o Currículo do Estado de São Paulo?

Os autores que irão contribuir para esta pesquisa fazem parte do referencial que abarca a Teoria Histórico-Cultural, a Psicologia Histórico-Cultural e a Pedagogia Histórico-Crítica, para além dos filósofos que amparam as reflexões propostas pelo Materialismo Histórico-Dialético.

A pesquisa de campo, amparada a partir de uma intervenção didáticopedagógica, ocorreu no ano de 2017, ano em que esta professora teve atribuídas turmas das $1^{\underline{a}}$ e das $3^{\underline{a}}$ séries do Ensino Médio, na disciplina de Filosofia, no período matutino. Neste ano, esta professora tinha 8 turmas de $1^{\text {a }}$ série e 2 turmas de $3^{\text {a }}$ série, em uma escola estadual pública pertencente à região metropolitana de São Paulo, mais precisamente no município de Cotia, jurisdicionado à Diretoria Regional de Ensino de Carapicuíba.

A execução do plano de ensino ocorreu para cerca de 360 escolares com a idade entre 14 e 20 anos, de ambos os gêneros. A escolha por apresentar estes números em sua totalidade é apontar que a atividade pedagógica e filosófica esteve presente em todas as turmas, no entanto, por questões metodológicas optou-se aqui por apontar os dados de uma única turma, que representa as possibilidades, limites e reveses da realidade concreta caótica e plural.

É ainda importante apontar que a execução do plano de ensino e de aula ocorreu a partir do primeiro dia letivo de 2017, período em que a professora ainda não havia ingressado no curso de Doutorado. Assim sendo, a metodologia para análise dos dados é embasada na estrutura de uma pesquisa documental (RICHARDSON, 1999), a saber, um criterioso estudo acerca dos registros e documentos produzidos no decurso das aulas ministradas em 2017. Isso significa que haverá restrição quanto ao uso de algumas imagens, vídeos e 
áudios em que os sujeitos indicaram que não se sentiriam à vontade em sua exposição.

Para compor a análise documental foram utilizados os registros pessoais da professora, devidamente assentados em um caderno, as produções dos escolares, fotos, vídeos e gravações de aulas que compuseram o diário vivo de um plano de ensino e de aulas que foram executadas no transcurso da trajetória desta pesquisa.

Acerca da utilização do Currículo da Secretaria da Educação do Estado de São Paulo (SÃO PAULO, 2012) este foi adequadamente estudado para que o conhecimento teórico, assim como os conceitos filosóficos, se tornasse o mediador da atividade pedagógica e filosófica na prática didática, mormente, porquanto a intenção era valer-se da integração entre o cognitivo, afetivo e o volitivo como eixos motrizes para o desenvolvimento das funções psicológicas superiores dos escolares.

Dessarte, a professora desta pesquisa se anuncia como uma das últimas cavaleiras do apocalipse em 2017, haja vista que vivenciava pela primeira vez como professora a saída ${ }^{6}$ da Filosofia enquanto componente curricular, experimentava o caos e as contradições na realidade concreta do que já havia estudado nas transições da legislação e das políticas públicas e, concomitantemente, se coloca como sujeito consciente de sua função social numa desesperada (mas sistematizada) luta contra um sistema de ensino que não apenas nega aos sujeitos o acesso a um determinado tipo de conhecimento sob a bandeira de uma formação integral, mas que tira sua armadura de boas intenções, declaradamente, ao promulgar como eficaz e eficiente um rol de itinerários formativos ${ }^{7}$ vazios para os mais pobres.

Esta professora, ao vivenciar a história assinalada na dissertação de Mestrado, agora em âmbito Federal e não só no Estadual, se fortalece na luta

\footnotetext{
6 Diz-se saída porquanto a Filosofia, assim como outros componentes curriculares, serão absorvidos pelos itinerários formativos e porque a lei que promulga a atual Reforma do Ensino Médio retira a sua obrigatoriedade enquanto componente curricular.

7 Itinerários formativos é o nome dado ao conjunto de componentes curriculares que são constituídos por componentes curriculares, projetos oficinas e afins de uma ou mais áreas do conhecimento. Ver mais em http://portal.mec.gov.br/publicacoes-para-professores/30000uncategorised/40361-novo-ensino-medio-

duvidas\#: :text=Os\%20itiner\%C3\%A1 rios\%20formativos\%20s\%C3\%A30\%20o,poder\%C3\%A3 ०\%20escolher\%20no\%20ensino\%20m\%C3\%A9dio, último acesso em 30/10/2021.
} 
para superar o que é imposto ao proletariado por meio da atividade filosófica, por isso, intencionalmente e em atividade, se organiza e mobiliza ações e operações, para que os indivíduos se apropriem do modus operandi da Filosofia, a saber, a passagem do senso comum para a consciência crítica.

É válido ainda ressaltar que assim como esta pesquisa buscou promover um tipo específico de desenvolvimento, o Estado também propicia um tipo de desenvolvimento. Para que se possa analisar que tipo de formação, desenvolvimento e aprendizagem a esfera governamental propõe aos jovens, o capítulo que abre esta tese vai apresentar a historicidade do movimento de algumas políticas públicas, sob a óptica das transformações por que passou 0 ensino da Filosofia. 


\section{AS CONTRADIÇÕES HISTÓRICAS SOBRE O ENSINO DE FILOSOFIA NO ENSINO MÉDIO}

A presença da Filosofia, enquanto componente curricular pertencente à grade de ensino das escolas básicas, se apresenta na história dos processos de escolarização do Brasil como uma incógnita, isso porque a garantia de sua existência na sala de aula depende diretamente do contexto sociopolítico em que se encontra o país.

Ademais, são as condições concretas que geram a necessidade da presença ou ausência do ensino de determinados componentes curriculares nos bancos escolares, assim como a própria constituição do currículo depende diretamente das condições impostas pela realidade concreta, sendo esse um fenômeno que não se restringe apenas ao Brasil, mas que é perceptível em escala global.

A Filosofia, assim como os demais componentes curriculares, está nos processos de escolarização para promover a progressão da aprendizagem e o enriquecimento cognitivo, conforme apregoa a maioria das políticas públicas. É evidente que aquelas servem a um referencial teórico, abalizado pelas formas de experimentar os processos de escolarização de uma dada sociedade, e são essas políticas que comandam a forma e a fôrma em que são colocados os conhecimentos teóricos ministrados no espaço escolar.

A análise dos principais documentos e das teorias que abordam o ensino da Filosofia em sala de aula aponta que não só sua existência depende da constituição política e social do país, mas que, sobretudo, o caráter de sua execução também é reflexo da realidade de uma determinada demanda da sociedade, seja no que concerne às questões de orientação moral e ética ou aos interesses de mercado.

Assim, o ensino da Filosofia, que a princípio poderia promover a saída do estudante de um conjunto formulae mentis, provenientes de um pensamento enraizado em crenças e preconceitos oriundos do senso comum, para um pensamento crítico e ponderado, acerca das experiências da realidade concreta, também esteve e está a serviço das necessidades sociais. 
Nesta pesquisa, entende-se que a Filosofia deveria estar inserida no Currículo para transformar os escolares ${ }^{8}$ em estudantes, por meio do desenvolvimento de funções psicológicas superiores específicas como, por exemplo, a atenção, o domínio de conduta, a afetividade e a consciência crítica que pensa e considera a coletividade.

Destarte, a justificativa para as inúmeras entradas e saídas do ensino da Filosofia da grade curricular não considerou as necessidades de aprendizagem dos sujeitos, mas as da sociedade em que eles estiveram e estão submersos. Assim, é o caráter dado à escola que promulga a letra da lei e as políticas públicas educacionais, que dão contorno às formas de ensino e aprendizagem.

\subsection{Os Marcos Legais para o Ensino da Filosofia na Educação Brasileira - LDB, PCN/EM PNE}

As primeiras reformas educacionais no Brasil aconteceram no século XVI com os jesuítas, que foram os primeiros a trazer a experiência do ensino escolar para o país e a catequese é apenas um dos exemplos. Estas reformas afetaram não só o ensino de Filosofia, mas os processos de escolarização de forma geral.

É importante destacar que alguns manuais pedagógicos, as políticas públicas e a história apontam a Filosofia como componente curricular pouco necessário à grade curricular brasileira, por isso, ora é colocado em evidência, ora como opção como será abordado adiante. Contudo, é justamente este caráter efêmero nos bancos escolares, dependente da roda da fortuna política, que mostra que a Filosofia é tão essencial à formação humana e crítica, por isso o seu forçoso afastamento da escola é sempre atendendo ao pedido dos capatazes mercadológicos.

\footnotetext{
${ }^{8}$ Como supramencionado, o escolar assume esta função por se encontrar inserido no contexto escolar, porém, quando em atividade de estudo é estudante. No decurso da análise de dados, este indivíduo passa a ser considerado como escolar/estudante, por estar transitando entre as funções, posto que o desenvolvimento é caótico e dialético, mas, neste caso, tende a ser direcionado positivamente para a promoção de saltos qualitativos.
} 
É válido salientar que o modo como a educação escolar é tratada no país reflete a forma como é estruturada a sociedade tanto econômica quanto politicamente, como predito. Assim, a escola é apresentada de formas variadas, dependendo diretamente das intenções e estrutura social da realidade concreta em que ela está submersa e isso se reflete na constituição da grade curricular diretamente.

A Filosofia é um exemplo de componente do currículo que sofre com as alterações da legislação, não apenas por sua retirada, mas porque recebe uma tratativa específica, que ora permite que seu conteúdo recaia em um espontaneísmo, ora em um exacerbado academicismo e ora é relegada como pseudo componente curricular, porquanto sua tratativa fique restrita a ser incorporada ou não como conteúdo de outros componentes da grade de ensino, em nome da interdisciplinaridade.

De acordo com Freire (2016), a Filosofia começou a se apresentar no Brasil ainda no período colonial, imbuída de certo caráter propedêutico, haja vista que sua finalidade era conduzir os sujeitos, cujo poder aquisitivo permitia, a se alçarem ao Ensino Superior na Metrópole. Neste tempo, o ensino de Filosofia tinha o caráter de instrumentalizar os escolares com os ideais e pensamentos advindos da ciência natural daquele período.

Já que o contexto econômico e político dá o tom das relações humanas e estrutura as mudanças da sociedade no decurso do tempo, com a crise do modelo feudalista que regia Portugal, a consolidação do sistema capitalista por meio da Revolução Francesa e mais tarde da Revolução Industrial, as relações escolares também foram alteradas.

Os processos que culminaram na consolidação do capitalismo fazem com que os ideais burgueses, que ascendem à posição de classe social dominante, passem a orientar todos os campos da sociedade, pois são os seus interesses que movimentam toda a estrutura social, dividindo e diferenciando os sujeitos conforme a classe a que pertencem. Desta feita, o acesso às esferas social, política, econômica e cultural é pautado por profundas divergências e o mesmo ocorre nos processos de escolarização. Ademais, toda mudança histórica impacta diretamente a forma como a escola opera.

Conforme Freire (2016), no Brasil pode-se sucintamente apontar que as principais reformas educacionais ocorreram: 


\begin{abstract}
Século XVI e XVII
A educação escolar era pautada no modelo educacional da metrópole portuguesa da Companhia de Jesus, ordem religiosa católica pertencente aos jesuítas, contexto em que a Filosofia aparece impregnada por seus interesses e projetos, a fim de que os dogmas da Igreja e os interesses da coroa portuguesa fossem contemplados com êxito.
\end{abstract}

\title{
Século XVIII
}

No Período Pombalino $^{9}$ a Filosofia passa a ter caráter de ciência natural, que auxilia a instrumentalizar a modernização econômica da metrópole. Nesse período, que perpassa a história do Brasil Colônia até o término do Período do Brasil Império, a Filosofia se estabeleceu por seu caráter propedêutico para dar elementos conceituais necessários a fim de garantir o acesso dos escolares ao Ensino Superior ${ }^{10}$. Por causa do Período Aurífero, a necessidade de dotar os sujeitos de conhecimentos científicos, principalmente para a mineração e afins, foi o foco da educação escolar neste período.

No Período da República houve inúmeras reformas educacionais no Brasil, o que a faz ser colocada ora em evidência, ora como opção ao escolar, à instituição de ensino ou ao Estado. As reformas implantadas visavam formar a burguesia nascente e a mão de obra, para a nova organização social, influenciada por ideais liberais e positivistas. A educação escolar passou a ser prerrogativa do Estado, conquanto nesse período a cisão com a Igreja Católica se tornara ainda mais intensa. A crença de que a educação seria o meio para resolver parte dos problemas do país, embasada no positivismo, fez com que na última década da República a instrução propiciada pela escola tivesse importância cada vez maior em seus diversos níveis. Essas alterações constantes implementadas pelas políticas educacionais assinalam o movimento de extinção gradativa da Filosofia do currículo que se manifesta, num primeiro momento, na redução de carga horária nas grades curriculares, até a retirada total dos currículos das escolas públicas.

Séculos XX e XXI do ciclo colegial, no que denominavam ensino secundário com a duração de no mínimo três anos,

9 O Período Pombalino (1750-1777) é assim denominado devido às reformas implementadas na metrópole e nas colônias portuguesas pelo primeiro-ministro de Portugal, o conde de Oeiras e Marquês de Pombal, Sebastião José de Carvalho e Melo. Pombal, que no campo da educação, organiza uma reforma político-pedagógica que retira a Companhia de Jesus e sua estrutura pedagógica do ensino escolar, para organizar uma educação laica e liberal (FREIRE, 2016).

10 Os processos de escolarização no país inicialmente visavam dar formação (letrar) apenas a burguesia, lembrando que a universalização da educação escolar é produto do século XX. O ensino, como explicitado, tem sua estrutura atrelada ao modelo político e econômico vigente conforme cada momento histórico específico. Desta forma, o ensino da Filosofia é redirecionado na educação escolar segundo essas circunstâncias e seus propósitos atendem às políticas educacionais que estão direcionadas para determinados interesses. Nesse momento, poucos tinham acesso à educação escolar, cuja função era, por meio de aulas isoladas, apresentar os conhecimentos necessários para o ingresso nos cursos superiores da Europa. A Filosofia, assim como a escolarização, precisava imprescindivelmente estar voltada para o mundo prático, para as necessidades sociais mais imediatas (FREIRE, 2016). 
conforme o disposto no Capítulo II, artigos 44 ao 46. No entanto, este ensino era na modalidade optativa, de livre escolha pelo estabelecimento, nas duas primeiras séries do colegial ou organizada em um currículo diversificado, na terceira série do colegial ${ }^{11}$.

Lei № 5.692, de 11 de agosto de 1971, a LDB 1971: Pontua que o ensino de $1^{\circ}$ e $2^{\circ}$ graus tem por objetivo geral proporcionar ao escolar a formação necessária ao desenvolvimento de suas potencialidades no que diz respeito ao preparo do indivíduo para o domínio de recursos científicos e tecnológicos na qualificação para o trabalho e preparo para o exercício consciente da cidadania ${ }^{12}$.

Lei 7.044 de 18 de outubro de 1982: Altera o disposto na Lei 5.692/1971, no que se refere à profissionalização compulsória dos escolares, pois cabia à instituição de ensino a inserção da habilitação profissional em seu plano de ensino, como o disposto no artigo 5‥ Esta lei também abre espaço para a parte diversificada do currículo, entretanto, o ensino da Filosofia não se consolida.

Lei 9.394, de 20 de dezembro de 1996, a LDB de 199613: não assegura à Filosofia o caráter de componente obrigatório. A letra da lei não evidenciou sua obrigatoriedade, o art. $36, \S 1^{\circ}$, inciso III, indicava que ao final do Ensino Médio o escolar deveria demonstrar, dentre outros aprendizados, o "domínio dos conhecimentos de Filosofia e de Sociologia necessários ao exercício da cidadania", o que na prática indicava que os conteúdos filosóficos poderiam estar incluídos de quaisquer formas, mas não especificamente em um componente curricular.

Lei 11.684, de 2 de junho de 2008: Altera o art. 36 da Lei 9.394, de 20 de dezembro de 1996, incluindo

a Filosofia e a Sociologia como disciplinas obrigatórias em todas as séries do Ensino Médio.

Quadro 1: O Ensino da Filosofia no Brasil do Século XVI até o fim da primeira década do Século XXI (Elaboração própria)

11 Antes da exclusão da Filosofia dos bancos escolares, ela esteve incluída de certa maneira, pelo menos do ponto de vista legal e na letra da lei, na formação dos escolares por meio da LDB de 1961. Neste período em que a Filosofia era posta como opção, cabia ao Conselho Federal e os Conselhos Estaduais a decisão de uma gama de componentes curriculares optativos, entre os quais poderia estar ou não a Filosofia, e dentro das possibilidades colocadas por estes conselhos, cabia às instituições a escolha final. Esta lei, que permitia às escolas compor livremente a grade curricular entre os componentes obrigatórios e os complementares, antecipa que a Filosofia era considerada componente optativo, pois pouco poderia contribuir para uma formação tecnicista, objetivada anos depois com a LDB de 1971. A Filosofia também estava posta de certo modo como meio responsável pela formação de professores na LDB 1961, leiase o Capítulo IV, art. 59 e ainda o art. 63. No entanto, esta lei prevê que se não houvesse profissionais habilitados nos componentes curriculares específicos, estes poderiam ser ministrados por quaisquer profissionais liberais de cursos superiores correspondentes ou técnicos diplomados na especialidade.

12 Evidentemente que se tratava de um tipo específico de cidadania, haja vista que nesta época o Brasil passava pelo Regime Militar (1964-1985), que assinalava que alguns saberes poderiam ser considerados potenciais de riscos à soberania política do país e irem de encontro às diretrizes do Estado de Segurança Nacional. A LDB de 1971 nem ao menos cita a palavra Filosofia no corpo do seu texto, sua presença poderia ser justificada por se asseverar no art. 4 que os currículos do ensino de $1^{\circ}$ e $2^{\circ}$ graus teriam um núcleo comum, obrigatório em âmbito nacional, e uma parte diversificada para atender, conforme as necessidades e possibilidades concretas, às peculiaridades locais, os planos dos estabelecimentos e às diferenças individuais dos alunos. A lei especifica quais as disciplinas teriam o caráter obrigatório, no entanto, não especifica a exclusão de quaisquer disciplinas. Desta feita, a partir da promulgação da LDB de 1971 a Filosofia foi retirada do currículo, e foi apenas com o movimento de redemocratização do país, na década de 1980, que ela retornou paulatinamente (FREIRE, 2016).

${ }^{13} \mathrm{~A}$ pesquisa refere-se ao texto original. 
O quadro acima apresenta de modo sucinto como as leis modificaram a estrutura dos sistemas de ensino no decurso da história e ele era atual, no momento inicial da pesquisa, porém, no começo do ano de 2017 foi implementada a Reforma do Ensino Médio. Com ela, leis, documentos e outras políticas públicas são incorporadas ao cenário objetivo deste estudo, corroborando mais uma vez que nos processos de escolarização, cada classe social tem tipo de ensino e, de forma explícita, agudiza as diferenças de escola e estudo, ofertadas a cada público.

A Lei 13.415, de 16 de fevereiro de $2017^{14}$, alterou a Lei 9.394, de 20 de dezembro de 1996, a LDB de 1996. Esta nova lei indica a progressiva ampliação da carga horária mínima da educação básica, a integralização de novos componentes curriculares e dos itinerários formativos como obrigatórios por meio da Base Nacional Comum e tira da Filosofia e da Sociologia, assim como de outros componentes curriculares, o título de componentes curriculares para performar, segundo a reescrita do artigo 36, "arranjos curriculares, conforme a relevância para o contexto local e a possibilidade dos sistemas de ensino". Esta Lei ficou marcada pelo ensino transversal por áreas e pelo retorno da incorporação de profissionais de notório saber, como na LDB de 1961. É sob o obscurantismo desta Lei que a professora-pesquisadora e a pesquisadoraprofessora inicia seus estudos no Doutorado, elabora seu plano de ensino interventivo e começa a análise do caos de dentro e a partir do caos.

Em suma, a historicidade dos processos escolares aponta que o ingresso na escola a princípio não era e não é para todos, porquanto quando ele está condicionado a determinadas condições, impossibilitando os sujeitos de se alçarem às máximas possibilidades de desenvolvimento à genericidade humana.

Isso expressa que os processos de escolarização no decurso do tempo não foram inclusivos, porquanto havia e ainda há condições que se tornam

\footnotetext{
${ }^{14}$ Lei esta que altera as Leis 9.394, de 20 de dezembro de 1996, que estabelece as diretrizes e bases da educação nacional, e 11.494, de 20 de junho 2007, que regulamenta o Fundo de Manutenção e Desenvolvimento da Educação Básica e de Valorização dos Profissionais da Educação, a Consolidação das Leis do Trabalho - CLT, aprovada pelo Decreto-Lei n' 5.452 , de $1^{\circ}$ de maio de 1943, e o Decreto-Lei $n^{\circ} 236$, de 28 de fevereiro de 1967; revoga a Lei $n^{\circ} 11.161$, de 5 de agosto de 2005; e institui a Política de Fomento à Implementação de Escolas de Ensino Médio em Tempo Integral.
} 
impeditivas para o ingresso das camadas mais pauperizadas da sociedade na escola. Para além disso, quando estes estão na escola, isso não significa que foram incluídos porque lá estão, posto que o jogo do sistema capitalista é justamente marginalizar os incluídos, dando-lhes determinadas condições de escola e de estudo, justificando este fenômeno por meio de algumas correntes filosóficas e pedagógicas que, para além de fundamentar as causas do fracasso escolar, inspiram e condicionam as alterações na estrutura da grade curricular.

Assim, tem-se que os processos de escolarização não eram e não são um direito de todos na prática, haja vista que o discurso da meritocracia aponta que nem todos podem se alçar à apropriação de determinados conhecimentos. O discurso da meritocracia construído no decurso da história dos processos de escolarização indica que cabe ao indivíduo por suas capacidades individuais esforçar-se para alcançar determinados lugares da sociedade. Contudo, sabese que não são dadas as mesmas condições, para que todos se alcem, por seu próprio mérito, às máximas possibilidades do gênero humano.

Voltando para a legislação supramencionada, acerca da Reforma do Ensino Médio, dada pela Lei 13.415 de 16 de fevereiro de 2017, o seu texto retoma, de certo modo, o viés de uma escolarização tecnicista da LDB de 1971. Daí, para compreender a estruturação e o processo histórico no qual se pauta o Currículo do Estado de São Paulo, que subsidia a intervenção didáticopedagógica desta pesquisa, se faz preciso olhar mais atentamente para a LDB de 1996, a fim de compreender as entradas e saídas do ensino de Filosofia e seus desdobramentos.

Por conseguinte, é preciso asseverar, por exemplo, que o texto de 1996, que não tinha a intenção de incorporar a Filosofia como componente curricular, é uma equivocada interpretação do Projeto de Lei anterior, posto que o texto original de 1988, o Projeto de Lei Complementar 1.258/1988, revelava no art. 48, cap. IV, em sua redação final, a inclusão da Filosofia e da Sociologia como componentes curriculares obrigatórios, ao passo que a Lei 9.394/1996 ignorou tal execução (FREIRE, 2016).

Ainda sobre o assunto, a deliberação CEE 10/1997 e as resoluções da Secretaria da Educação do Estado de São Paulo (Seduc-SP) implementadas no ano de 1998, a Resolução SE 7, de 19 de janeiro de 1998 no art. 8, e a Resolução SE 10, de 23 de janeiro de 1998, que inclui anexos III e IV na mesma 
Resolução SE 7 supra, por sua vez, colocaram que os conteúdos de Filosofia e Sociologia seriam contemplados como temas específicos dos componentes curriculares já existentes, não como dois componentes cogentes a compor a grade curricular das instituições de ensino.

Freire (2016) assevera à luz da LDB de 1996 e das leis acima mencionadas, excetuando a de 2008, que nenhuma delas assinalaram a obrigatoriedade de incorporar a Filosofia como componente curricular, mas sim como conteúdo que poderia perpassar os demais como tema transversal, diluído na área de Ciências Humanas e suas Tecnologias, como normatiza os Parâmetros Curriculares Nacionais para o Ensino Médio (PCN/EM) (BRASIL, 1999b).

Neste texto já havia a menção à construção e organização curricular da Base Nacional Comum Curricular do Ensino Médio, estruturando a sistematização do currículo e de sua proposta pedagógica, bem como agrupando os saberes por áreas curriculares. As Ciências Humanas comportariam as competências vinculadas à compreensão do significado da sociedade e da cultura, articulado aos estudos de Filosofia e Sociologia, estas "relacionadas à apropriação dos conhecimentos dessas ciências com suas particularidades metodológicas" (BRASIL, 1999, p. 93). Além disso, o texto é claro ao dizer que

[...] é indispensável lembrar que o espírito da LDB é muito mais generoso com a constituição da cidadania e não a confina a nenhuma disciplina específica, como poderia dar a entender uma interpretação literal da recomendação do inciso III do Parágrafo primeiro do Artigo 36. Neste sentido, todos os conteúdos curriculares desta área, embora não exclusivamente dela, deverão contribuir para a constituição da identidade dos alunos e para o desenvolvimento de um protagonismo social solidário, responsável e pautado na igualdade política. (BRASIL, 1999b, p. 93)

O que o texto corrobora objetivamente é que não há necessidade de que haja tantas disciplinas e/ou componentes curriculares para trabalhar os estudos de Filosofia e Sociologia, por exemplo, e que toda proposta curricular deveria se ater à LDB vigente, assim como seguir as normas estabelecidas por leis e pareceres complementares.

O PCN/EM através da organização curricular por áreas e de uma compreensão que se diz transdisciplinar e matricial, outorga a articulação entre 
as linguagens, a Filosofia, as ciências naturais, humanas e as tecnologias, propondo uma compreensão que supere um ensino estanque $e$ compartimentalizado, no entanto, na prática, nenhuma alteração significativa fora feita para além de políticas públicas cujas ações foram focais e isoladas, como o Ensino Médio em Rede ${ }^{15}$ da Seduc-SP, dispensando a Filosofia e sua especificidade enquanto componente curricular.

Neste contexto, conforme o quadro apresentado, foi apenas no ano de 2008 que a Filosofia foi oficialmente incluída como componente curricular obrigatório no Ensino Médio no Brasil juntamente com a Sociologia por meio da Lei Federal 11.684, de 2 de junho de 2008. Esta lei revogou o inciso III, do $\S 1$, do art. 36 da LDB de 1996, que passou a vigorar com a inclusão do inciso IV: "[...] serão incluídas a Filosofia e a Sociologia como disciplinas obrigatórias em todas as séries do Ensino Médio".

Esta alteração fortaleceu um movimento que já estava em processo e, desta feita, os currículos estaduais passaram por uma readequação. São Paulo, por meio de sua Secretaria de Estado da Educação, criou um currículo específico, contemplando o que fora posto pela lei de 2008, e nisso se enquadra o contexto particular desta pesquisa, desenvolvida em uma escola pública do Estado de São Paulo no ano de 2017, valendo-se deste currículo, que será abordado adiante.

Continuando com a historicização dos desdobramentos da LDB de 1996, o Plano Nacional de Educação (PNE), Lei 13.005, de 25 de junho de 2014, por seu turno, abriu mais uma vez a discussão para a necessidade de uma reforma e revisão geral das políticas públicas da Educação Básica com vistas a alcançar as metas traçadas pelo Índice de Desenvolvimento da Educação Básica (Ideb ${ }^{16}$ ) e no cumprimento do disposto no art. 214 da Constituição Federal.

15 Ação da Secretaria do Estado da Educação se propunha articular os vários componentes curriculares da grade curricular com a finalidade de se propor um trabalho interdisciplinar, na intenção de que os escolares observassem os conteúdos não de forma segmentar ou fragmentária, mas vinculados com o contexto social e científico de sua época. Neste período, no Estado de São Paulo havia em algumas regiões o ensino da Filosofia, Sociologia e Psicologia por causa da legislação federal permitir a autonomia aos Estados no que diz respeito a constituição da grade curricular.

${ }^{16} \mathrm{O}$ Ideb (Índice de Desenvolvimento da Educação Básica) é um modo de monitorar a qualidade da Educação por meio de dados concretos obtidos através do Saeb (Sistema Nacional de Avaliação da Educação Básica), composto por uma prova e pelo exame do fluxo escolar, a análise destes dados é responsável pela criação de políticas públicas que visam estabelecer metas para melhoria do aprendizado no âmbito nacional em comparação com os índices dos 
Parte de sua expressão é a mencionada Lei 13.415, de 16 de fevereiro de 2017, conversão da Medida Provisória no 746 de 2016, que tinha por finalidade promover a revisão da LDB de 1996 e impactou diretamente e, mais uma vez, na atuação e presença do ensino de Filosofia, dado por meio de um componente curricular específico, como será exposto adiante.

Antes, é preciso apontar que não colocar na letra da lei que há um componente curricular específico para tratar dos temas da Filosofia, desobriga o Estado da contratação de profissionais habilitados tanto para a formação de professores neste âmbito, quanto para a atuação em sala de aula na Educação Básica, assim como para a formulação de um material adequado e todo um repertório, que poderia instrumentalizar acertadamente quem fosse trabalhar com os temas da Filosofia em sala de aula. Todavia, como predito, a Lei 13.415, de 16 de fevereiro de 2017, cuidou disso deliberando a possibilidade de contratação de profissionais com notório saber, prática já comum no período da LDB de 1961, como supracitado.

Compreende-se, por conseguinte, que há, conforme cada projeto pedagógico e política pública, um espaço maior, menor ou inexistente para a Filosofia na grade curricular das escolas, assim como há um tipo específico de Filosofia que é contemplada segundo tais princípios.

Para encerrar esse breve panorama histórico do ensino da Filosofia, que não pretendeu ser pormenorizado, por não ser objetivo principal desta pesquisa, mas sim atender à categoria da historicidade e para melhor compreensão do que é a Filosofia para os processos escolares, conclui-se que um espaço maior para a Filosofia não significa exatamente um grande espaço para o filosofar, enquanto reflexão crítica da realidade objetiva dentro da sala de aula. Ampliar esse espaço pode denotar, por exemplo, um modo velado de controlar o conteúdo e os temas da Filosofia de modo geral.

A seguir, para abordar a particularidade desta pesquisa, o Currículo Paulista será apresentado, no que diz respeito à Filosofia, e será estudado com a intenção de apontar as possibilidades e limites do ensino no ano de 2017 nos

países desenvolvidos. No Estado de São Paulo, para além desta métrica, há o Idesp (Índice de Desenvolvimento do Estado de São Paulo), cujo indicador é obtido por meio do Saresp (Sistema de Avaliação de Rendimento Escolar do Estado de São Paulo) e do fluxo escolar. 
bancos escolares do Estado de São Paulo e que pode oferecer subsídios que possibilitem ainda a compreensão do processo escolar hodierno.

\subsection{O Currículo Paulista, o Ensino da Filosofia e a Reforma do Ensino Médio}

Em 2017, ano em que esta pesquisa foi desenvolvida, o Currículo do Estado de São Paulo, que antes era conhecido como Proposta Curricular do Estado de São Paulo, era um dos principais documentos para nortear o ensino nas escolas estaduais. Ele foi posto como política pública pela Secretaria da Educação do Estado de São Paulo (Seduc-SP) em 2008, por meio da Coordenadoria de Gestão da Educação Básica (CGEB), e tinha como pressuposto ser um Currículo base para os Anos Iniciais e Anos Finais do Ensino Fundamental e Ensino Médio. O Currículo fazia parte de um programa de unificação de ações pedagógicas, no que diz respeito tanto a execução de conteúdos em sala de aula, quanto a normatização de novas diretrizes de gestão escolar, fundamentadas nas metas estabelecidas pelo Idesp (Índice de Desenvolvimento da Educação do Estado de São Paulo) ${ }^{17}$.

A intenção deste Currículo era de fornecer uma base comum de conhecimentos e competências que, utilizada por professores e gestores, possibilitasse que as escolas funcionassem de forma articulada, pautada pelos mesmos objetivos. Pesava também o fato de a Secretaria de Estado da Educação observar que os índices de São Paulo estavam abaixo do que fora estabelecido pela Federação por meio do Ideb (Índice de Desenvolvimento da Educação Básica) e, por causa disso, no decurso dos anos a Seduc-SP lançou mão de alguns recursos para mensurar e quantificar a aprendizagem e o ensino.

Assim, o Currículo do Estado de São Paulo era composto por um conjunto de materiais que incluíam os Cadernos do Professor e Cadernos do Aluno,

\footnotetext{
${ }^{17}$ Como supramencionado, o Idesp é um indicador que mensura a qualidade das séries iniciais e finais do Ensino Fundamental e do Ensino Médio. O Idesp tem o papel de apontar quantitativamente os pontos em que é preciso melhorar a aprendizagem, o ensino e o fluxo da escola.
} 
organizados por componente curricular, de acordo com o ano ou série e bimestre. Neles, eram apresentadas sequências didáticas denominadas de situações de aprendizagem ${ }^{18}$, com a finalidade inicial de orientar o trabalho do professor no ensino dos conteúdos considerados base para a aprendizagem dos escolares, a ideia era ter um material que seria o norte de um conteúdo mínimo comum para todo o Estado, a posteriori e, no transcurso dos anos, este material tornou-se obrigatório, passando por poucos ajustes.

No início do ano de 2015 a Seduc-SP publicou as diretrizes da política educacional para definir quais eixos e ações deveriam reger as práticas pedagógicas e, com isso, lançou alguns instrumentos e materiais de apoio, entre eles, a Matriz de Avaliação Processual (2016). Este material abordava os conteúdos gerais por ano/série e vinculava as situações de aprendizagem ao desenvolvimento de competências e habilidades específicas, apontando em um quadro, o que o escolar deveria aprender bimestralmente. A proposta era fornecer subsídios que norteassem um trabalho que seria quantificado por meio de uma prova denominada AAP (Avaliação de Aprendizagem em Processo ${ }^{19}$ ), realizada nas unidades escolares inicialmente por bimestres.

Para acompanhamento deste trabalho, que deveria ser realizado pelos professores, a equipe gestora contava com o chamado alinhamento curricular, em que o professor coordenador analisava os registros dos escolares em seus cadernos pessoais e comparava-os aos registros dos professores em seus diários de classe, ao Currículo e ao Plano de Ensino, elaborado pelo professor, com a finalidade de observar se os dados evidenciavam a convergência desses registros para uma prática única e se eles estavam em conformidade com a realidade objetiva.

Esta ação, de acordo com a política da Seduc-SP, tinha a intenção de alinhar práticas e metodologias, no entanto, poderia ser considerada também

18 Situação de aprendizagem refere-se ao nome dado pela Seduc-SP para uma determinada sequência didática. Segundo as orientações da Seduc-SP, cada situação de aprendizagem obedecia ao critério de partir do mais simples sobre um determinado conhecimento até chegar ao mais complexo.

${ }^{19}$ A Avaliação de Aprendizagem em Processo é uma espécie de termômetro para o Idesp (Índice de Desenvolvimento da Educação do Estado de São Paulo), servindo como indicador de qualidade dos Anos Iniciais ( $1^{\circ}$ a $5^{\circ}$ anos) e Finais (6ㅜ a $9^{\circ}$ anos) do Ensino Fundamental e do Ensino Médio (1 $1^{\mathrm{a}}, 2^{\mathrm{a}}$ e $3^{\mathrm{a}}$ séries), durante o ano letivo, para que ao fim a aprendizagem, o ensino e o fluxo fossem mensurados pela prova Saresp (Sistema de Avaliação de Rendimento Escolar do Estado de São Paulo). 
como meio de fiscalização, haja vista que a implementação do Currículo desde o começo era vista por parte do corpo docente, como uma prática arbitrária e impositiva.

A propósito, quando o Currículo fora implementado a princípio houve por parte do corpo docente grande movimentação contra sua execução, alegando que a imposição era desmedida e se configurava como quebra de cátedra, conforme disposto na Lei Federal de 5 de outubro de 1988, em seu artigo 206음 e na Lei 9.394 de 20 de dezembro de 1996, em seu artigo 3‥ Os professores declaravam que a unificação, mesmo pensando em um conteúdo mínimo, não levava em consideração as especificidades de cada município do Estado, tampouco as necessidades de cada unidade escolar e dos escolares individualmente.

Desta forma, alguns professores resistiram ao cumprimento do Currículo em sala de aula, enquanto outros modificavam a estrutura e a ordem do que era denominado sequência didática do material. Já outra parte do corpo docente atendeu tacitamente ao proposto pelo Currículo, já que observava que o material poderia ser um facilitador da prática do ensino em sala de aula.

O questionamento, que advém de executar ou não este Currículo, deveria estar para além de atender ou não uma dada política pública, porquanto deveria caber ao professor o estudo minucioso do material, a fim de decidir por utilizá-lo ou não, ou ainda fazer uma adaptação. Porém, na prática não havia esta prerrogativa.

É importante salientar que não realizar a análise do material a ser utilizado em sala de aula, implica em alienar o trabalho pedagógico em seu propósito último e primeiro, já que pensar a categoria trabalho, de acordo com a teoria marxiana é, nestes termos, ter o trabalho humano enquanto meio necessário para satisfazer e objetivar determinadas necessidades, que neste caso é propiciar a formação e o desenvolvimento dos sujeitos submersos nas relações escolares. Por outro lado, pela lógica do trabalho alienado, ao professor cabe tão somente preparar os estudantes, para serem capazes de responder ao Saresp, por isso, há a necessidade alienada de cumprir o que está (im)posto, exatamente da forma como está proposto, no Currículo.

A necessidade de um professor que se conscientizou de sua função social é buscar formas que impactem a consciência/personalidade do 
escolar/estudante, tendo o conhecimento teórico como mediador do desenvolvimento das funções psicológicas superiores. Neste processo, existem outros instrumentos e elementos, ações e operações que afetam a condução deste trabalho. No entanto, é preciso compreender que o desenvolvimento da consciência do que é a função do professor é um movimento que depende do exercício de uma atividade que seja adequada a um fim, guiada por um desejo, um sonho, uma vontade, um fim. Afinal de contas, a educação escolar deve ser um trabalho que tem como fim produzir um ser humano-histórico (PARO, 2010b, p. 91).

Nesta reflexão do que era feito na prática a partir da implantação do Currículo, entende-se que este tinha uma função afastada do referencial teóricometodológico da Psicologia Histórico-Cultural e da Pedagogia Histórico-Crítica, porquanto sua estrutura e, por consequência, conteúdo estavam embasados na teoria construtivista. Esta teoria era [e ainda é] interpretada de forma geral pelas políticas públicas brasileiras, como a que melhor contempla o tipo de ensino e de aprendizagem a ser ofertado nas escolas, sobretudo, as públicas.

A análise pormenorizada e histórica das políticas públicas mobilizadas pela letra da lei aponta que, em verdade, o que se tem na prática é um apenas um recorte de uma miscelânea de teorias, que estruturam e subsidiam os documentos orientadores de metodologias de ensino (DUARTE, 2004a, 2004b; LIBÂNEO,1999; MIZUKAMI, 1986).

Um outro propósito do material era ser um guia conteudista, cujo propósito era servir de apoio e base para realização das provas AAP, Saresp e Saeb, a fim de alavancar o aumento de seu percentual quantitativo, diante dos índices do Idesp e do Ideb, como predito de certa forma. Antes da implementação do Currículo, a Seduc-SP não possuía uma orientação unificada no que diz respeito à sequência didática dos conteúdos de cada componente curricular, o que prejudicava diretamente os resultados do Estado nas avaliações externas, pois não havia o controle do que era ministrado em sala de aula e, consequentemente, não havia o processo de preparação uniforme e ad hoc, a fim de garantir os índices esperados nessas avaliações.

O escolar, antes do Currículo, ao realizar as provas, poderia ter tido acesso e estudado o conteúdo delas ou não, dependendo diretamente da estrutura dos planos de ensino e de aula, assim como dos guias de 
aprendizagem de cada professor, unidade escolar, diretoria de ensino e municípios. Com o Currículo, o conteúdo prescrito para a prova, estava (dis)posto nesse documento, de forma única e numa progressão determinada.

Desta maneira, o Currículo unificou a ordem das sequências didáticas e garantiu o acesso a determinados conteúdos para que as avaliações externas pudessem mensurar a aprendizagem com parâmetros adequados às suas métricas. É por isso que, no decurso do tempo, as diretorias regionais de ensino aderiram cada vez mais ao alinhamento curricular, a fim de observar se os professores estavam ou não cumprindo a sequência didática determinada ${ }^{20}$.

E assim, os resultados das provas internas e externas também poderiam apontar a execução ou não do material e se ele era adequadamente utilizado, posto que os conteúdos da prova da AAP (Avaliação de Aprendizagem em Processo), que era mensurado periodicamente, durante o ano letivo, e o do Saresp (Sistema de Avaliação de Rendimento Escolar do Estado de São Paulo), que era mensurado ao fim de cada Ciclo de ensino, confluíam para o que prescrevia o Currículo e se materializava no Caderno do Aluno. Portanto, como predito, com o passar do tempo a utilização do material passou a ser obrigatória, assim sendo, todas as ações da Seduc-SP passaram a ser voltadas para a análise do cumprimento de seu conteúdo e da sequência didática, engessando o trabalho dos professores que não estavam atentos às possibilidades de trabalhar com as brechas das políticas e orientações da Seduc-SP.

Se existiam instrumentos para quantificar como era o processo de ensino e de aprendizagem em cada escola e enquadrar a aprendizagem, mensurada na escala de proficiência organizada nos níveis abaixo do básico, básico, adequado e avançado, que eram pautados nos conteúdos das provas que estavam fundamentadas na estrutura do Currículo, de acordo com as orientações da Seduc-SP, havia também a possibilidade aos professores de adaptarem o Currículo se os escolares/estudantes não possuíssem as habilidades e competências necessárias para se apropriarem de determinados conhecimentos previstos para aquele ano/série/ciclo. Assim, os professores poderiam ter a

20 A Diretoria Regional de Ensino (DRE) orientou a equipe gestora da escola, em que esta professora trabalhava, que, caso o professor não utilizasse o Currículo, ele poderia ser oficiado via DRE, no Diário Oficial, sobretudo, se não houvesse justificativa prévia, em seu plano de ensino, para a adequação curricular, ou o porquê de não usar o Caderno do Aluno, por exemplo. 
liberdade de adaptar o Currículo, elaborando formas de administrar seus conteúdos de modo a atender às especificidades das turmas e/ou dos sujeitos singulares. Isso deveria ser devidamente registrado pelo professor em seu Plano de Ensino e analisado pela equipe gestora da escola para sua execução.

O Plano de Ensino e o Plano de Aula, por exemplo, podem receber na parte de estratégias e metodologias o que a Seduc-SP denomina de Plano de Intervenção e/ou Plano de Ensino Individualizado ${ }^{21}$. O professor também pode elaborar estes documentos de forma separada, desde que a partir de uma análise da realidade escolar, por meio de dados coletados de avaliações diagnósticas devidamente documentadas e apresentadas à equipe gestora, em especial ao Professor Coordenador responsável pela parte pedagógica da escola, como supramencionado. Estes planos referem-se às práticas que visam sistematizar ações que adequem o ensino às necessidades dos escolares, a fim de alavancar sua aprendizagem.

A apropriação desses instrumentos pela professora se deu no decurso da execução do experimento didático na pesquisa de Mestrado (FREIRE, 2016) e em sua trajetória como Professora Coordenadora de escolas públicas do Estado de São Paulo nos anos de 2015 e 2016, por meio do estudo criterioso do Currículo e das políticas públicas vinculadas a ele.

Mas já em 2017 foi possível propor uma intervenção pedagógica em sala de aula, tendo o Currículo como conteúdo mínimo obrigatório; assim, foi preciso que a professora buscasse meios para integrar o Plano de Ensino a um documento complementar, o Plano de Intervenção. Esse expediente se torna necessário, porque quaisquer adequações ao Currículo necessitam de uma justificativa, a fim de apontar que apesar da alteração, a intenção é atender às especificidades dos escolares, como supradito.

Tem-se por pressuposto que se há um Currículo da Seduc-SP (SÃO PAULO, 2012) imposto e, concomitantemente, ele não se mostra eficaz, para o que fora elaborado, mesmo considerando sua reelaboração em curso, as contradições veladas são inevitavelmente expostas.

21 Usualmente o termo Plano de Ensino Individualizado é utilizado especificamente para denominar um dos documentos que subsidiam o trabalho da Educação Especial, contudo, em casos severos de problemas de escolarização é possível utilizar este instrumento. 
Aqui cabe apontar que ao analisar as políticas públicas à luz de seus resultados, seja as avaliações internas, como a Avaliação da Aprendizagem em Processo (AAP), seja as avaliações externas, como o Sistema de Avaliação de Rendimento Escolar do Estado de São Paulo (Saresp), é possível verificar que o produto dos processos pelos quais passam crianças, jovens e adultos está longe de evidenciar grandes avanços para uma mínima formação, aprendizagem e desenvolvimento de qualidade superior.

Como assinalado, a definição da eficiência de como é abordado o Currículo/Caderno do Aluno em sala de aula parte da análise dos dados do Idesp. No ano de 2019, dois anos após a intervenção didático-pedagógica desta pesquisa, as principais mídias apontaram números alarmantes: 7 de cada 10 alunos da $3^{a}$ série do Ensino Médio estavam no nível abaixo do básico em Língua Portuguesa e em Matemática. Isso se agudizou com o ano pandêmico de 2020, pois o Banco Mundial estimou que as perdas esperadas de aprendizagem, apesar de todos os esforços de ensino remoto, foram enormes, uma vez que, antes da pandemia, $50 \%$ dos estudantes possuíam um nível de proficiência abaixo do básico e, após 13 meses de escolas fechadas, no ano letivo de 2021, esse índice poderia chegar a $71 \% 22$.

Isto significa dizer basicamente que o nível de proficiência alcançado pelos alunos na $3^{\underline{a}}$ série do Ensino Médio era o esperado para o 9ํano do Ensino Fundamental II. O mesmo foi identificado nos números lançados pelo Sistema de Avaliação da Educação Básica (Saeb), instrumento de medida Federal, que visa medir e subsidiar que se alcance o rendimento e as metas determinados pelo PNE ${ }^{23}$.

Desta forma, o distanciamento dos sujeitos submersos no seio escolar da apropriação do conhecimento teórico, bem como da cultura elaborada sóciohistoricamente e até mesmo das condições mínimas para compreensão, análise e crítica é evidente a olhos vistos, haja vista que os números expressam o

${ }^{22}$ Fonte https://brasil.un.org/pt-br/124506-artigo-importancia-de-indicadores-de-educacao-paramedir-os-impactos-da-pandemia, último acesso em 21/07/2021.

${ }^{23}$ Fonte https://g1.globo.com/educacao/noticia/2018/08/30/7-de-cada-10-alunos-do-ensinomedio-tem-nivel-insuficiente-em-portugues-e-matematica-diz-mec.ghtml,

https://www.educacao.sp.gov.br/destaque-home/secretario-rossieli-soares-apresenta-detalhessobre-dados-saresp-2018/ e http://pne.mec.gov.br/18-planos-subnacionais-de-educacao/543plano-nacional-de-educacao-lei-n-13-005-2014, último acesso em 29/05/2019 
crescimento do fracasso escolar não apenas no ano de 2019, mas nos anteriores e hodiernamente.

Por meio desta percepção integral da realidade, abalizada por uma diagnose das turmas, foi necessário averiguar a possibilidade de se valer de brechas da legislação, para fazer com que esta pesquisa se colocasse em movimento a fim de objetivar e expressar na práxis pedagógica ${ }^{24}$ o supramencionado no objetivo, objeto e no problema de pesquisa. Porquanto, de acordo com o referencial adotado, é necessário buscar meios que possibilitem a superação das contradições hodiernas em uma estrutura educacional caótica e que se direciona para o desmanche da Filosofia, enquanto componente curricular obrigatório, que deveria permanecer para [com os demais] promover um ensino voltado à formação, aprendizagem e desenvolvimento da consciência crítica nos indivíduos pertencentes ao caos da escola pública estadual paulista.

Tudo isso dito para corroborar o porquê da readequação da sequência didática, da justificativa do uso parcial do material ofertado pela Seduc-SP, no que concerne a utilização integral do Caderno do Aluno, e da (re)organização do conteúdo teórico-filosófico, explicações estas que serão apresentadas a posteriori na explicitação da intervenção didático-pedagógica que será testificada no capítulo que trata da pesquisa de campo.

A intenção foi seguir a máxima filosófica de que sua atividade deve partir do senso comum, mas não permanecer nele, e sim perpassar pelo abstrato, deste para o concreto e do concreto para o concreto pensado (FREIRE, 2016), pois num trabalho que se pretende apresentar a Filosofia ao escolar/estudante, esta apresentação deve se dar, a partir de sua gênese, considerando, mormente, suas características ontogenéticas.

Como predito, se a Lei Federal 11.684, de 2 de junho de 2008, garantia à Filosofia o posto de uma componente curricular obrigatório e apontava a necessidade de conteúdos e métodos específicos, o processo da Reforma do Ensino Médio, cujo produto imediato é a Lei 13.415, de 16 de fevereiro de 2017,

24 De acordo com Vázquez (1977), a práxis é uma atividade conscientemente orientada, com a intenção de integrar teoria e prática na transformação das dimensões objetivas e subjetivas da atividade. A práxis pedagógica, por seu turno, é a organização e planejamento de ações e operações voltadas intencionalmente para a transformação do contexto escolar e, por conseguinte, dos sujeitos submersos em seu seio, direcionando-os para as máximas possibilidades da genericidade humana. 
que altera a Lei n 9.394, de 20 de dezembro de 1996 (Lei de Diretrizes e Bases da Educação Nacional), a retira mais uma vez da grade curricular ${ }^{25}$.

A Reforma do Ensino Médio, promulgada pela Lei 13.415 de 16 de fevereiro de 2017, é a responsável pelas atuais mudanças nos currículos dos Estados da Federação e mostra que as grandes alterações se expressam apenas pela progressiva retirada de determinados componentes da grade curricular e a sua substituição por elementos exóticos, contemplados pela parte diversificada da BNCC e por seus itinerários formativos, à configuração do espaço escolar, a fim de garantir uma instrumentalização da Pedagogia dos Projetos $^{26}$ e promover uma formação aos estudantes que atenda às demandas de ordem técnica do capital.

No Estado de São Paulo seu impacto recai diretamente sobre os resultados expressos pelo Saresp e Saeb, porquanto apesar de os textos das políticas públicas mascararem seu objetivo principal, a prática não nega para quê e para quem veio, a saber, treinar os escolares para realização destas provas, no que concerne ao aprimoramento de uma estrutura que qualifica pela quantificação a aprendizagem destes.

A Lei 13.415, de 16 de fevereiro de 2017, refere-se à Filosofia, enquanto estudo que perpassa os itinerários formativos, no artigo $3^{\circ}, \S 2^{\circ}$ aponta que a "Base Nacional Comum Curricular referente ao Ensino Médio incluirá obrigatoriamente estudos e práticas de educação física, arte, sociologia e filosofia". O artigo $36^{\circ}$ da Lei 11684/2008 colocava a Filosofia enquanto componente curricular obrigatório, fora alterado substancialmente, e passou a ter a seguinte redação no artigo $4^{\circ}$ da referida lei "o currículo do Ensino Médio será composto pela Base Nacional Comum Curricular e por itinerários formativos, que deverão ser organizados por meio da oferta de diferentes arranjos curriculares, conforme a relevância para o contexto local e a

\footnotetext{
${ }^{25}$ Antecipa-se aqui o argumento que será posto adiante, diferentemente da Lei 11684, de 02 de junho de 2008, a Lei da Reforma do Ensino Médio não indica que a Filosofia está incluída como disciplina obrigatória, mas sim que, como indica o artigo $3^{\circ} \S 2^{\circ}$, ela é um estudo obrigatório". Asseverar que é estudo e/ou prática obrigatória não significa necessariamente que haverá a permanência da Filosofia enquanto componente curricular, ao contrário, ela volta ao limbo, atuando como conteúdo que pode perpassar as áreas do conhecimento.

26 Metodologia didática que se intitula ativa, em que há o pretenso incentivo a uma visão interdisciplinar do conhecimento. $\mathrm{O}$ aprendizado e o desenvolvimento da autonomia dos escolares ocorrem, por vezes, de maneira intuitiva, por meio da experiência em projetos pedagógicos.
} 
possibilidade dos sistemas de ensino, a saber: I -linguagens e suas tecnologias; II - matemática e suas tecnologias; III - ciências da natureza e suas tecnologias; IV - ciências humanas e sociais aplicadas".

A (re)organização e (re)estruturação destas políticas públicas para que atendam adequadamente o que denominam por nível de proficiência é urgente. Contudo, a esta professora mais urgente é (re)adequar o que é imposto às reais necessidades dos escolares/estudantes, haja vista que os documentos curriculares oficiais nem sempre atendem e/ou observam as suas especificidades, tampouco a realidade multifacetada das mais variadas realidades escolares.

A retirada da obrigatoriedade de parte significativa dos componentes curriculares é justificada na letra da lei pela intencionalidade de formar um cidadão integral, contudo, não se indica em seu corpo como um ensino pode se intitular integral, quando cerceia o direito dos sujeitos de acessarem determinados tipos de conhecimento, que são de suma importância para o seu processo de humanização por meio da escola.

Outro ponto de suma importância é reiterar o porquê há a necessidade da permanência da Filosofia enquanto componente curricular, porquanto se a intenção das atuais reformas é propiciar uma formação que seja integral, a retirada de quaisquer componentes curriculares, e não apenas da Filosofia, denota o quão contraditórias podem ser as políticas públicas educacionais em curso, como predito.

Justifica-se a retomada de forma reiterada do texto da legislação de 2017, porquanto ele é como um fantasma que se materializa, com o anúncio da saída da Filosofia enquanto componente curricular, preocupação que esta professorapesquisadora anunciava em sua pesquisa de Mestrado, pois indicava que o medo acerca da Filosofia

[...] enquanto componente curricular consolidada pela letra da lei não deixa de existir, sobretudo, quando se sabe que a lei não assegura o cumprimento de seu texto na prática por si só. A possibilidade de que uma resolução ou outra lei venha a revogar o exercício da Filosofia como disciplina escolar é, e a história mostra o porquê, um constante fantasma (FREIRE, 2016, p. 84). 
Este excerto denunciou e, concomitantemente, mostrava ponderada e assertivamente a apreensão acerca da seguridade incerta de se ter a Filosofia enquanto componente curricular, posto que as necessidades e a estrutura da sociedade sempre foram o que determinaram a fôrma e a forma dos sistemas de ensino.

Retirar a obrigatoriedade da Filosofia do corpo de conteúdos dos currículos propicia o eterno retorno da ausência de oportunidades ao adequado acesso e apropriação de conhecimentos de extrema importância para a constituição e desenvolvimento das funções psíquicas superiores dos escolares/estudantes.

Tal afirmação fica mais explícita pela incorporação do já mencionado notório saber da Lei 13.415, de 16 de fevereiro de 2017, que outorga que não há necessidade de que as "ciências humanas e aplicadas" sejam ministradas por profissionais habilitados, já que no inciso IV do artigo $61^{\circ}$ está disposto que

profissionais com notório saber reconhecido pelos respectivos
sistemas de ensino, para ministrar conteúdos de áreas afins à sua
formação ou experiência profissional, atestados por titulação
específica ou prática de ensino em unidades educacionais da rede
pública ou privada ou das corporações privadas em que tenham
atuado, exclusivamente para atender ao inciso $V$ do caput do art. 36 .
(BRASIL, 2017).

Na escola pública estadual paulista isso significa dizer que haverá a longo prazo uma espécie de dissolução dos conteúdos e conhecimentos específicos nos componentes curriculares pertencentes à base comum - que contempla os componentes curriculares tradicionais - e à parte diversificada - formada a princípio por Projeto de Vida, Eletivas e Tecnologia e Inovação e depois é suplementada pela inclusão das Unidades Curriculares ${ }^{27}$, à medida em que os componentes presentes na base comum desaparecem - da BNCC e dos demais projetos que serão elaborados nas unidades escolares.

Para os professores conscientes de sua função social, isso significa a instituição de uma escola pobre aos pobres, já que na escola pública os

${ }^{27}$ É válido salientar que cada Estado da Federação está adotando sua própria versão da BNCC, assim sendo, cada um possui um rol de itinerários formativos e unidades curriculares, isso porque a BNCC não é um Currículo, mas um documento orientador para que cada Estado construa sua identidade pedagógica. 
escolares serão privados da apropriação dos nexos causais dos conceitos mediadores da aprendizagem e do desenvolvimento, em detrimento de uma escolarização que se diz integral, mas em verdade é a promoção de uma pedagogia de projetos (DUARTE, 2001).

A verdade é que é difícil apontar quaisquer caminhos, seja pela continuidade ou não da Filosofia enquanto componente curricular no futuro. Todavia, é importante notar que as políticas públicas são pautadas pela letra da lei e ela neste momento mostra o que ocorrerá com a grade curricular e, mais particularmente, com a Filosofia nos bancos escolares.

Levando em consideração o peso da letra da lei e do caos implementado pela Reforma do Ensino Médio, faz-se necessário apresentar sucintamente este contexto, pois é justamente neste período de transição [de sanção da legislação da Reforma do Ensino Médio, também conhecido como Novo Ensino Médio, e início da implantação da BNCC] que se encontra a execução da intervenção didático-pedagógica, a escrita teórica desta pesquisa e a análise dos dados coletados.

Como apontariam Hannah Arendt (2005) e Eric Hobsbawn (1998), a história tem muito a nos ensinar, sobretudo, a não incidir nos erros já cometidos. Todavia, o caminho que seguem as políticas públicas educacionais no Brasil é outro, sempre se teima em cruzar o reino de areias movediças das Reformas. A análise hodierna dos documentos que as referendam, dos contextos e da historicidade da Filosofia enquanto componente curricular, mostra que existem elementos contraditórios e caóticos na intersecção da BNCC e na reelaboração do Currículo Paulista.

A Teoria Histórico-Cultural e a Pedagogia Histórico-Crítica fizeram suas denúncias acerca desta tendência, para além disso, a Língua Portuguesa aponta seu significado de forma veemente. Reformar é dar uma nova forma ao que já existia, ou seja, a antiga forma ganha uma nova versão. Talvez por isso a escolha por Reformas seja uma opção intencional dos Governos para as políticas pedagógicas brasileiras.

Neste contexto, isso significa que o que já era posto desde a Constituição de 1988, a respeito da BNCC (Base Nacional Comum Curricular), juntamente com outras legislações, algumas mostradas nesta pesquisa, foi integrado em um texto em conformidade com as atuais demandas. 
Deste modo, a partir da aprovação da lei do Novo Ensino Médio os materiais curriculares buscaram se adequar à $B N C C$, tanto no que diz respeito ao conteúdo quanto à forma. A BNCC, por conseguinte, trouxe alterações à estrutura da grade curricular do Ensino Médio, porque impôs aos Estados da Federação a necessidade de rever e realinhar a estrutura dos currículos. Isso tanto é verdade que a Seduc-SP ao final de 2018 começou a reorganizar o Currículo Paulista para o Ensino Fundamental sob a vigência do então Governador de Estado, Márcio França e, no início de 2019, lançou o Guia de Transição Curricular, incluindo os conteúdos do Ensino Médio, com o Governador João Dória no poder.

A proposta do Guia foi fornecer aos professores um documento orientador com sugestões de trabalho e, de certa maneira, oferecer um material que servisse como ponto de partida para a construção do novo Currículo a partir de 2020/2021. Este material se colocou como um subsídio que não se pretendeu engessador, haja vista que apontou que sua intenção era "que esses materiais de cada componente possam ser adaptados e reeditados pelo professor conforme o desenvolvimento das atividades realizadas com seus alunos" (SÃO PAULO, p. 2, 2019).

É importante notar que este Guia fora escrito como mecanismo orientador para o $1^{\circ}$ Bimestre e que nos demais bimestres do ano de 2019 não houve a produção de material semelhante, o que pode ser considerado uma falha ou não da Seduc-SP, sobretudo, quando se pesa que um ano letivo tem quatro bimestres e que há inúmeras cobranças acerca dos planejamentos que devem ser realizados pelos professores, no entanto, ele não foi realizado por quem cobra, estabelecendo mais uma vez o caos.

Esse texto ainda apontou que não haveria grandes alterações nos conteúdos, habilidades e competências para o ensino de Filosofia, já que o referencial fundamental e o desenvolvimento de competências e habilidades descritas no Currículo do Estado de São Paulo já convergiam para os Parâmetros Curriculares Nacionais (PCN) (BRASIL, 1999) e para as Orientações Curriculares Nacionais ( $\mathrm{OCN}$ ). Contudo, o tilintar do tempo mostrou que essa era uma inverdade, posto o que houve em seguida.

Nestes termos, o ensino de Filosofia que já era direcionado à três dimensões, a saber, a leitura, a escrita e a oralidade, retornava ao lugar de 
subsídio temático, com a finalidade de perpassar os itinerários formativos da área de Ciências Humanas e Sociais Aplicadas (CHSA) e afins, o que significa que a Filosofia de certa forma volta para o lugar ocupava no PCN do Ensino Médio de 1999, como predito.

Apesar de o Currículo Paulista de 2017 ainda não assumir isso, a Lei da Reforma do Ensino Médio de 2017 dava mais um indício, quando apresenta os itinerários formativos para Novo Ensino Médio. Sobre os itinerários formativos, eles são o conjunto de componentes curriculares dados por meio das áreas do conhecimento (linguagens e suas tecnologias, matemática e suas tecnologias, ciências da natureza e suas tecnologias, ciências humanas e sociais aplicadas e formação técnica e profissional (FTP) ${ }^{28}$ ), sejam individualmente ou mesmo nos conhecimentos de duas ou mais áreas integradas à FTP. Eles possuem o formato de projetos, oficinas, núcleos de estudo, entre outras situações de trabalho que ocorrerão na escola sistematizados em uma Matriz de Ementas e na MAPPA (Material de Apoio ao Planejamento e Práticas de Aprofundamento) ${ }^{29}$ (isso na Seduc-SP).

O texto da Lei da Reforma do Ensino Médio, assim como da BNCC e das ementas dos itinerários formativos (SÃO PAULO, 2021), revela seu cunho tecnicista e, numa análise pormenorizada, é possível asseverar que tal política pública aprofunda desigualdades, pois coloca um tipo de ensino diferenciado quando observado o fato que se a letra da lei não obriga a oferta de componentes curriculares específicos, ela também não os proíbe na rede privada de ensino.

Os itinerários são o substrato para atender à demanda da educação integral indicada pela BNCC. Entende-se por educação integral, tanto na BNCC quanto no Currículo Estadual Paulista, àquela que se designa como servidora de uma determinada necessidade, e a atual, segundo a Reforma do Ensino Médio, está para servir às necessidades mercadológicas da sociedade brasileira.

28 Referência https://www.gov.br/pt-br/noticias/educacao-e-pesquisa/2021/07/novo-ensinomedio-comeca-a-ser-implementado-gradualmente-a-partir-de2022\#: : :text=Os\%20itiner\%C3\%A1rios $\% 20 \mathrm{~s} \% \mathrm{C} 3 \% \mathrm{~A} 30 \% 3 \mathrm{~A} \% 20$ linguagens $\% 20 \mathrm{e}, \mathrm{e} \% 20$ forma \%C3\%A7\%C3\%A30\%20t\%C3\%A9cnica\%20e\%20profissional, último acesso em 30/07/2021. 29 Ver mais em https://novoensinomedio.educacao.sp.gov.br/ e https://efape.educacao.sp.gov.br/acao-formacao/novo-ensino-medio-aprofundamentocurricular-unidade-curricular-1/, último acesso em 13/08/2021. 
O seu texto remete ao PCN e OCN ao apontar a que vem a Filosofia nestes, o seu trabalho como conteúdo interdisciplinar deve ser articulado com diferentes conteúdos e modos discursivos nas mais variadas ciências, nas artes e em outras produções culturais, como predito. Para cada habilidade prevista ao ensino de Filosofia no antigo Currículo, deve-se promover a articulação daquela com as habilidades e competências socioemocionais, apontadas nas competências gerais da BNCC.

É válido salientar que a BNCC é um documento orientador e não um currículo fechado e imposto a toda Federação, pois cada Estado será responsável por elaborar seu próprio currículo, utilizando-se da BNCC e da lei que a norteia como base e ponto de partida para a sistematização de seus conteúdos. Como supramencionado, no Estado de São Paulo a Secretaria da Educação implementou um Currículo (SÃO PAULO, 2012) próprio e único, no final da primeira década dos anos 2000, como meio estruturador obrigatório para a elaboração dos planos de ensino e de aulas; em 2016 a Matriz de Avaliação Processual (SÃO PAULO, 2016) foi lançada como guia orientador para o que denominam aprendizagem de habilidades e competências, dentro de uma dada sequência didática a ser executada em sala de aula. Em 2019 foi lançado o Guia de Transição e em 2021 o Currículo em Ação, com o objetivo de integrar o que já existia à proposta da BNCC tão somente. A Reforma, assim, vai ganhando seus documentos legais paulatinamente.

Dito isso, é possível asseverar que os sistemas de ensino retornam aos ideais positivistas em que uma escolarização específica deve ser dada em conformidade com o público ao qual está destinada. Isso porque, se não houver mudanças nas provas de acesso ao Ensino Superior, por exemplo, fica evidente que o seu ingresso será direcionado tão somente para uma parcela da população, o que já ocorre de certo modo, haja vista que há uma disparidade nos processos de ensino e aprendizagem para ricos e pobres, conforme aponta Freire (2016). A legislação da Reforma do Ensino Médio, assim como a letra posta na BNCC, aponta que o conteúdo das provas de ingresso do Ensino Superior passará por alterações para se adequar a esta proposta da BNCC, contudo o que se observa nos vestibulares nesse período de transição é a 
permanência no modelo anterior [fixado nos componentes curriculares tradicionais, apesar da Resolução 03 de 21 de novembro de 201830].

E é neste processo, portanto, que há a dissolução não só da Filosofia enquanto componente curricular diluída nas áreas do conhecimento, mas de praticamente todos os demais componentes curriculares. Assim, esta professora se vê com uma das últimas oportunidades de ministrar a Filosofia ainda no patamar de componente curricular oficial, desolada por perder a possibilidade de permanência da Filosofia nesta modalidade e sem previsão de retorno a esta via por uma política pública, entristecida porque a política assinala o notório saber como uma alternativa à ausência de professores habilitados [ao invés de ofertar formação adequada aos professores], mas se vê também como a última cavaleira em meio a este caos apocalíptico de contradições.

Este contexto é dado aqui não como pretexto, mas como pano de fundo, a fim de indicar o porquê esta professora se autointitulou como a última cavaleira do apocalipse, pois sua intervenção didático-pedagógica ocorre justamente quando foi sancionada a Reforma do Ensino Médio legalmente. Por isso, antes da intervenção didático-pedagógica no ano de 2017, houve um estudo minucioso acerca do Currículo a ser adaptado e é evidente que todo o processo mencionado acima afetou diretamente a produção deste texto e a análise dos dados após a qualificação. Seria possível inclusive asseverar que foi a batalha contra $o$ caos $e$ as contradições que fizeram emergir as categorias desta pesquisa e o substrato teórico para a atividade de estudo desta professora a respeito da integração da cognição, da afetividade, das volições e das vivências como meios para o desenvolvimento da consciência crítica por meio do Ensino da Filosofia.

O próximo capítulo mostra que a Filosofia foi engendrada enquanto necessidade para promover a formação e o desenvolvimento do humano no homem e, concomitantemente, este processo de produção viva e dialética do humano no homem foi o responsável pela gênese da Filosofia como atividade filosófica, que está direcionada para produzir o conhecimento e conhecer o que é o conhecimento.

30 Ver mais em https://www.in.gov.br/materia/lasset publisher/Kujrw0TZC2Mb/content/id/51281622, último acesso em 20/07/2021. 


\section{A FILOSOFIA COMO MEIO PARA A FORMAÇÃO DA CONSCIÊNCIA CRÍTICA}

Como já fora apresentado anteriormente, a Filosofia no decurso da história da educação escolar no Brasil se mostra como aquele campo do saber cuja presença é efêmera e, quando presente, está à serviço do referencial teórico-metodológico adotado pelos sistemas de ensino.

No que diz respeito à presença da Filosofia nos currículos dos bancos escolares brasileiros, Freire (2016) assevera que mesmo estando presente na grade curricular e com espaço garantido como componente curricular, por meio da legislação vigente do período, isso não significa exatamente um espaço para o filosofar, enquanto reflexão crítica da realidade objetiva dentro da sala de aula. Assegurar sua presença conforme a lei pode, inclusive, denotar, como visto, um modo velado de controlar o conteúdo e os temas da Filosofia de modo geral.

Historicamente a Filosofia tem origem complexa e multifacetada. Às vezes preocupada em perscrutar minuciosamente questões ontológicas de cada tempo e buscar possíveis respostas e/ou análises que conduzissem a uma percepção esclarecida da realidade concreta, a partir de determinada perspectiva teóricofilosófica. Às vezes, ela se encontra comprometida em introjetar nos sujeitos verdades comprometidas com a pseudoconcreticidade, com determinismos, dogmas e doutrinações, numa reprodução ensimesmada e reiterativa do status quo.

Kosik (1969) aponta que a pseudoconcreticidade é um claro-escuro, em que o aspecto fenomênico da coisa se manifesta como essência e a "[...] diferença entre fenômeno e a essência desaparece" (KOSIK, p. 12, 1969). $\mathrm{Na}$ Filosofia, apesar da sua propensão à análise crítica, não podemos esquecer que esta crítica também pode ser deveras conservadora e voltada para atender às necessidades do capital.

Contudo, a Filosofia aqui trabalhada é compreendida como atividade humana engendrada a partir de uma necessidade, a saber, a promoção do desenvolvimento do humano no homem. A História da Filosofia indica que a necessidade que criou a Filosofia foi a de querer compreender o Universo, qual sua origem e quais são seus fenômenos, por meio de uma sistematização 
racional do que é natureza e seus processos inicialmente, através dos filósofos da physis, por nós conhecidos como filósofos da natureza.

A atividade, por conseguinte, é a unidade da vida do sujeito concreto, que o orienta no mundo dos objetos na satisfação de necessidades produzidas socialmente (LEONTIEV, 1983), que faz com que os objetos da realidade concreta sejam transformados em instrumentos e signos portadores de humanidade (DUARTE, 1993) por meio do processo de apropriação, transformação e objetivação da atividade humana sobre tais objetos.

E é assim que a Filosofia se constitui em atividade, sobretudo quando reflete que sua intenção radical é satisfazer as necessidades humanas produzidas socialmente, no que diz respeito à busca por conhecer o que é mundo, as coisas, o homem e o próprio conhecimento, colaborando com o desenvolvimento do homem enquanto gênero humano no movimento de apropriação, transformação e objetivação da atividade humana sobre os objetos objetivos e subjetivos.

Para além disso, parte da atividade da Filosofia também é promover a teorização da realidade prática e, por meio desta, irromper em uma práxis transformadora (VÁZQUEZ, 1977). A práxis transformadora contribui para a mediação do conhecimento que, ao ser apropriado, tem a possibilidade de transformar a realidade concreta, no caso da escola, de instituição produtora de contradições e de fracasso escolar, em instituição promotora de objetivação do ensino escolar, de produção de conhecimento e cultura, de constituição de vínculos cognitivos e afetivos, de novas volições e vivências, direcionadas ao desenvolvimento do pensamento por conceitos, crítico e autônomo.

O tornar teoria a realidade não significa criar teses inquestionáveis, mas sim elaborar um conhecimento teórico que fora sistematizado por meio do que foi apreendido, internalizado, apropriado e objetivado a partir da realidade objetiva, perpassando por uma crítica que vai até a raiz de suas questões, problemas e reveses, como supramencionado.

De acordo com a Teoria Histórico-Cultural, essa dimensão contempla a práxis transformadora porque é atividade conscientemente orientada com a intenção de integrar teoria e prática numa transformação não apenas das dimensões objetivas, mas também subjetivas da atividade. 
Desta feita, considera-se que a Filosofia, enquanto atividade, ao teorizar a realidade concreta, tem por necessidade transformá-la e não apenas pensála, porque se vale do conhecimento teórico, como mediador das relações humanas, contribuindo para a passagem do homem hominizado ao homem humanizado, (BERNARDES; MOURA, 2009; FREIRE, 2016) impactando o cognitivo, mas também o afetivo, os interesses, as necessidades, os desejos, as volições e as vivências.

A Filosofia, enquanto mediação e produção do conhecimento teórico, contribuiu e muito para as transformações e saltos qualitativos que ocorreram no homem, cuja primazia era sua fisiologia e suas funções elementares, imbricadas com a biologia da espécie hominizada, que laborava a natureza com a intenção de satisfazer necessidades, e culminou na produção do homem humanizado que, coletivamente, é criador de cultura.

Nesta pesquisa, interessa a origem da Filosofia vinculada à necessidade de engendrar conhecimento, transformar conceitos, sujeitos e sociedades. $\mathrm{Na}$ realidade concreta, o surgimento da reflexão filosófica no Ocidente, promoveu historicamente a formação das cidades-Estados, da democracia ateniense e a estruturação da política e da moral da sociedade grega, por exemplo.

Conforme afirma Vázquez (1977), integrar teoria e prática é essencial para analisar, compreender e transformar a realidade concreta, porquanto elas estejam isoladas, não oferecem mais do que está posto e imposto pela hodierna estrutura social. Entretanto, é válido salientar que não se trata de qualquer teoria e prática, já que o sistema possui um emaranhado multifacetado de teorias e práticas, as quais produzem efeitos improfícuos, haja vista a desigualdade social que gera inclusive impacto em como são (re)formuladas as reformas na Educação Básica das últimas décadas (e dos séculos passados também).

Dito isso, apesar de a Filosofia ser assumida aqui, como promotora de um movimento que faz com que o indivíduo se coloque a questionar, fato que, de antemão, poderia colocá-la como um componente curricular indispensável ao ambiente escolar, por propiciar um desenvolvimento peculiar às funções psicológicas, tem-se, no entanto, o eterno-retorno da sua diluição em temas e conteúdos de outras disciplinas ou, simplesmente, sua completa ausência, e esse é um fato que se mostra como contraditório, mas existente nas atuais redes de ensino. 
A contradição se expressa quando, por exemplo, as políticas públicas apontam a necessidade de uma formação integral, sem que se leve em conta que a presença e a ausência da Filosofia nos bancos escolares se tornou algo recorrente, ou, como compreende a Pedagogia Histórico-Crítica, um projeto ${ }^{31}$. Todavia, a presença da Filosofia também pode se apresentar contraditória, haja vista que a intenção do sistema capitalista é promover uma formação específica, em que sua presença não se faz necessária, a não ser que se trate de certa Filosofia, esvaziada de práxis revolucionária ${ }^{32}$.

Neste capítulo será apresentada de forma sumária, até mesmo porque não é este o objetivo principal desta tese, como a Filosofia se constituiu em conhecimento teórico que perfaz a práxis revolucionária para o desenvolvimento do humano no homem (VÁZQUEZ, 1977) e sua atividade na formação da consciência dos estudantes, sobretudo, na possibilidade de integrar cognição, afetividade, volição e vivências.

Isso significa dizer que será abordada a maneira pela qual a Filosofia passou de constructo que produz humanidade no homem, na medida em que é elaborada por ele, à componente curricular que impacta na formação e transformação da consciência dos que estão sob sua mediação.

\subsection{A Filosofia Enquanto Componente Curricular na Formação Humana}

Como assevera a filosofia kantiana ${ }^{33}$, o conhecimento até pode começar na experiência só que não para nela. Esta asserção aqui denota o próprio

\footnotetext{
31 Projeto no sentido da teoria da Pedagogia dos Projetos que incentiva a existência de uma metodologia de ensino que promova a integração das áreas do conhecimento com a intenção de ensinar e aprender por meio, tão somente, da experiência. Professores e estudantes são mobilizados a compartilhar perguntas, hipóteses, estratégias de pesquisa e alternativas de solução, o que aparentemente é interessante, mas esconde que o ponto de partida e o de chegada deste processo é o mesmo: o senso comum.

32 A práxis revolucionária é uma atividade teórico-prática em que a teoria se modifica constantemente com a experiência prática, que por sua vez se modifica constantemente com a teoria (VÁZQUEZ, 1977).

33 "[...] todo o conhecimento se inicia com a experiência, isso não prova que todo ele derive da experiência[...]. Há, pois, pelo menos, uma questão que carece de um estudo mais atento e que não se resolve à primeira vista; vem a ser esta: se haverá um conhecimento assim, independente da experiência e de todas as impressões dos sentidos. Denomina-se a priori esse conhecimento
} 
movimento de construção da Filosofia enquanto atividade humana, ou melhor, que para compreender a realidade objetiva de modo pormenorizado, faz-se necessária uma análise crítica, em que a partir do caos da empiria, lugar em que se constituem as relações humanas, é realizado um exame de suas possibilidades e entraves.

De acordo com Saviani (2015, p. 28), a construção do conhecimento e, por assim dizer, do pensamento, parte do empírico, passa pelo abstrato e chega ao concreto, ou seja, a passagem do empírico ao concreto se dá pela mediação do abstrato.

É por este caminho, que perpassa pela abstração do concreto-real para engendrar o concreto-pensado, que transitam a Filosofia e o pensar filosófico dialético, tendo em vista que sua compreensão de mundo não é linear, mas atividade que se propõe ir à raiz e desnudar os processos, a partir de seu próprio movimento (MARX, 2007).

Ademais, o que é essa tal dialética que, desde os tempos de Sócrates é tão comentada na Filosofia Ocidental, mas, efetivamente, pouco se vê acerca da sua real contribuição para o desenvolvimento geral da humanidade e mesmo das funções psicológicas superiores? No decurso deste e do próximo capítulo, caso este questionamento tenha surgido, espera-se que a resposta submerja.

Ontologicamente, a Filosofia rompe com um tipo de conhecimento que explicava o mundo e as coisas embasado em mitologias, não para apontar que havia outro ente de ordem superior, mas para mostrar que a forma como se deslinda os véus da realidade concreta, se dá a partir dos instrumentos que se tem em cada tempo e que eles expressam a necessidade de um dado período, até se constituir em novas necessidades (FREIRE, 2016; SAVIANI 1983).

A Filosofia originariamente nasce em um mundo, em que a descrição das coisas e das causas destas cabia às cosmogonias, em que os mitos davam conta de mostrar como eram os fenômenos e, em um determinado momento, esta maneira de se conceber a realidade não mais satisfez o homem.

Deste modo e por meio de um longo processo de apropriação e transformação da natureza, este tipo de conhecimento passou a questionar o 
porquê de tais abstrações estarem desvinculadas de processos que a physis poderia demonstrar de modo mais concreto, e disso a cosmologia veio a apresentar a primeira forma de pensar o mundo, racionalizando-o.

Isso não quer dizer que as cosmogonias não apresentavam certa racionalização do conhecimento empírico, em que se pese ter havido a organização de narrativas, com uma determinada intencionalidade. O ponto de ruptura com o mito se deu a partir do momento em que a Filosofia iniciou uma atividade outra, voltada para novas necessidades, afastando-se da carga religiosa, para explicar a origem do mundo, das coisas e das causas das coisas e do mundo.

Após racionalizar explicações acerca da natureza fenomênica e humana, a Filosofia esteve à serviço dos mais abastados, pois era ela quem dava voz e vez para a arte retórica nos discursos da Ágora ateniense. É válido salientar que neste período a cidadania dependia da riqueza e do nascimento na pólis. Quando a Filosofia esteve próxima aos menos privilegiados do período, irromperam situações conflituosas, como no caso do filósofo Sócrates.

Foi justamente ele quem provocou um movimento inédito na reflexão filosófica do Ocidente, pois volta a Filosofia, que até então estava ocupada com as ciências de forma geral ou com a prática política aristocrática e econômica da pólis, para ocupar-se com o humano no homem de forma dialética. E é por este movimento que é possível perceber que a Filosofia pode estar voltada, essencialmente, com a função do homem na compreensão de determinadas problemáticas de seu tempo e, para além disso, com sua formação, a partir de um dado contexto.

A Filosofia de certa forma acompanhou e acompanha o pêndulo histórico na Idade Antiga, Média, Moderna e Contemporânea, procurando examinar e deliberar acerca de suas principais problemáticas, contribuindo para o desenvolvimento das mais variadas teorias, para a elaboração e sistematização de estruturas políticas e sociais, para o nascimento de diversas Ciências, para a articulação de revoluções e para, sobretudo, integrar teoria e prática.

Este movimento perpassou a História da Filosofia, haja vista que a elaboração de seu arcabouço teórico sempre esteve ligado às necessidades, sejam elas do contexto em que estava submerso o filósofo, para compreendê-lo ou para analisá-lo, sejam elas às atinentes à subjetividade do autor, para atender 
às demandas internas ou externas (do contexto e do filósofo), sejam para servir ao seu tempo, alimentar ou criticar os valores de um determinado sistema, como predito de certo modo.

Para Saviani (1983), a atitude filosófica colabora com a objetivação deste movimento, porque cumpre com as exigências da reflexão filosófica que, segundo o autor, deve ser radical, rigorosa ${ }^{34}$ e de conjunto. Isso porque a atitude filosófica está voltada para recuperar a problematicidade do problema e a essência do problema é a necessidade. O que significa que a coisa em si filosófica é complexa e dialética, haja vista que a necessidade da Filosofia é querer saber da causa da coisa e das coisas, e que a necessidade da coisa e das coisas só é compreendida quando a Filosofia faz a análise da estrutura e a decomposição do todo, visando deslindar e superar a coisificação das coisas, conhecer sua essência e a problematicidade do problema que a compõe.

E mais, que a Filosofia enquanto atividade deve atuar com a finalidade de desconstruir a pseudoconcreticidade, ascendendo à consciência tanto nos aspectos objetivos quanto nos subjetivos mediando a formação da humanidade no homem. Atividade esta que tem importante função também na organização do pensamento, transbordante em linguagem, e da atividade prática, porquanto mobiliza o homem por meio de sua metodologia a querer saber se existe uma oculta verdade da coisa, afinal de contas, como aponta Kosik (1969) apropriando-se da teoria marxiana "[...] se a aparência fenomênica e a essência das coisas coincidissem diretamente, a ciência e a filosofia seriam inúteis" (KOSIK, 1969, p.13).

Voltando a Saviani (1983), a atitude filosófica é o que faz o homem ter a capacidade de avaliar e de refletir a respeito dos problemas, conscientizando-o de uma situação de necessidade (aspecto subjetivo), ou numa situação conscientizadora de necessidade (aspecto objetivo). É, pois, um re-pensar (SAVIANI, 1983, p. 22-23). Esta reflexão sobre os problemas que a realidade

\footnotetext{
${ }^{34}$ Saviani assevera que a atitude filosófica é radical, rigorosa de conjunto, porquanto 1. exige-se que o problema seja colocado em termos radicais, indo-se até às raízes da questão; 2. deve-se proceder com rigor, ou seja, sistematicamente, segundo métodos determinados, colocando-se em questão as conclusões da sabedoria popular e as generalizações apressadas que a ciência pode ensejar; 3. o problema não pode ser examinado de modo parcial, mas numa perspectiva de conjunto, relacionando-se o aspecto em questão com os demais aspectos do contexto em que está inserido (SAVIANI, 1983).
} 
apresenta, não é qualquer tipo de reflexão, é ela contemplada pela Filosofia, pois, a análise feita pela Filosofia exige, por sua vez, uma análise pormenorizada da realidade concreta.

Ademais, a atividade da Filosofia é descobrir o que está para além do que é manifestado de forma direta e imediata, pela realidade fenomênica, para perscrutar a estrutura da coisa e a coisa em si, que se apresenta no dia-dia, mas apenas de forma oculta e distorcida (KOSIK, 1969). Por isso, Freire (2016) lança mão da atividade filosófica. A atividade filosófica tem importante papel na mediação de conhecimentos de uma geração a outra e, a Filosofia não é qualquer tipo de conhecimento, ela é capaz de promover o desenvolvimento das funções psicológicas superiores, quando adequada e intencionalmente organizada para isso. Inclusive, uma das funções superiores que ela pode impactar, para além da formação do pensamento teórico, é a formação da consciência crítica e, por sua vez, do pensamento por conceitos, do pensamento abstrato e do pensamento dialético.

Assim, a atividade filosófica, engendrada a partir de um tipo específico de ensino da Filosofia, com a intenção de propiciar o desenvolvimento do pensamento teórico na vida objetiva dos estudantes, manifesta a necessidade humana de compreender a realidade concreta, a partir de seu contexto, tendo como princípio motor conhecer a história da Filosofia e sua conexão com o desenvolvimento do humano no homem, tendo o conhecimento teórico-filosófico como mediador, numa integração dos processos cognitivos, afetivos e volitivos na sala de aula.

Dito isto, a necessidade que aqui se coloca supera a condição em que se sopese tão somente o teórico e o prático de forma unilateral e linear, porquanto se faz preciso uma unidade de análise e de categorias que integrem, para além disso, o cognitivo, o afetivo, o volitivo e as vivências não em uma soma predicativa de isso e isso e isso, mas sim observando a unidade molar que propicia a reflexão sobre o movimento da realidade caótica. E que funcione como uma unidade íntegra, não fracionada, nem fruto da adição de suas partes (BERNARDES, 2006), pois 
cuja função real consiste em orientar o sujeito no mundo dos objetos. Em outras palavras, a atividade não é uma reação, tampouco um conjunto de reações, mas é um sistema que possui uma estrutura, passos internos e conversões, desenvolvimento. (LEONTIEV, 1983, p. $66)$.

O movimento de integração do cognitivo, do afetivo e do volitivo com as vivências é identificado em Freire (2016), mas não é explicitado para além da integração entre teoria e prática na atividade pedagógica. Todavia, a intenção desta pesquisa é evidenciar o que outrora não foi apresentado, já que as condições concretas no passado não garantiram as condições oportunas para esse processo.

É de suma importância, assim, conhecer esse passado a fim de obter um entendimento que esteja voltado a abarcar o todo, a partir de suas partes, e superar o que não mais pode ser repetido, para engendrar, brotando de uma análise minuciosa, uma nova atividade. Neste ponto cria-se uma pausa dramática, a partir do que Vigotski define como drama ${ }^{35}$, e, concomitantemente, um start para finalmente apontar como a Filosofia pode contribuir, enquanto conhecimento teórico, para a formação do humano no homem e, portanto, é preciso que a categoria história emerja, para auxiliar neste processo de explicação.

Tem-se, nesta pesquisa, que historicamente a atividade filosófica está presente quando, no processo de satisfação de necessidades, em que o homem precisa de instrumentos, símbolos e signos que promovam a adequada apropriação dos objetos da natureza e da realidade concreta. A Filosofia se posiciona em favor desse processo, como atividade mediadora na criação, na compreensão, na análise e na crítica desses elementos, produzindo cultura e, concomitantemente, humanidade.

A atividade filosófica tem importante papel na mediação de conhecimentos, apresentando aos homens os problemas da cultura e da

35 O Drama para Vigotski é, sobretudo, conflito. Cada etapa do desenvolvimento é como um ato de um drama, em que se altera o cenário, o roteiro ou parte dele e a conduta do ator por causa disso. O drama, desta feita, solicita uma suspensão por parte do ator para que ele possa emitir um juízo sopesado e adequadamente direcionado a uma meta. A volição, a partir disso, não pode emergir de maneira imediata, pois a tensão entre uma decisão e outra solicita ponderação, por isso, o drama. O drama, neste sentido, pode ser maior ou menor, dependendo do período crítico de desenvolvimento em que se encontra o sujeito (DELARI, 2011, 2020, 2021; VIGOTSKI, 1991, 2000b, 2006) 
sociedade de cada tempo e o que isso produziu no pensamento e nas teorias que por vezes irromperam em revoluções, haja vista que, por exemplo, Platão e Aristóteles influenciaram durante séculos formas de se pensar a lógica, o conhecimento, a política e as artes; e que as teorias de Descartes, Espinosa, Francis Bacon, Locke e Hume colaboraram para a elaboração de novos métodos que alavancaram as Revoluções Científicas dos séculos XVII e XVIII.

Ademais, a Filosofia aqui posta foi e é, há séculos, um meio que busca produzir conhecimentos na mediação das relações do homem com o mundo, no qual ele está submerso, preocupada sempre com a produção e com a reprodução de conceitos, linguagens e culturas.

É válido assinalar que por reprodução compreende-se que o indivíduo consegue recriar na atividade prática a maneira como se constituíram conceitos, linguagens e culturas, de tal modo a propiciar um movimento que as gerações ascendentes se apropriem dos procedimentos gerais que conduziram a elaboração do conhecimento teórico, reproduzindo-os em sua própria atividade (DAVIDOV, 1988).

A atividade filosófica, como um todo, também está voltada para que 0 homem possa sair de ações espontâneas e imediatas, para galgar formas superiores de comportamento, que possam orientá-lo na produção de meios que satisfaçam suas necessidades, seja no âmbito do querer compreender a origem das coisas, ou no questionamento acerca das bases dos problemas da realidade concreta.

$\mathrm{Na}$ análise da teoria marxiana, Duarte (2004a) aponta que o desenvolvimento do gênero humano se dá quando os processos sociais, que são produto de decisões coletivas e conscientes na atividade prática, permitem ao homem modificar a natureza e, concomitantemente, modificar a si mesmo a partir de sua atividade. Para além disso, este processo permite a ampliação de sua consciência na prática social, consciência esta que o faz capaz de planejar, marca típica do homem que se humaniza imerso nas práticas sociais.

Todo este movimento é apropriado pela Filosofia enquanto conhecimento teórico e que, por meio da atividade filosófica, propicia situações para que a humanidade do homem esteja voltada para o máximo desenvolvimento de suas funções psicológicas superiores. Sabe-se que na Teoria Histórico-Cultural a 
apropriação do conhecimento teórico, assim como da cultura elaborada sóciohistoricamente são mobilizadoras do desenvolvimento de funções superiores.

Contudo, in sese conhecimento teórico e cultura nada são. É por isso que, para se tornarem mediadores do processo de humanização do gênero humano e propiciadores do desenvolvimento das funções psicológicas superiores, a teoria e a cultura precisam ser mobilizadas num espaço em que se permita a troca de experiências, dialogicamente entre os indivíduos, e que esse par seja revivido para além da esfera simbólica - tal como os mitos são atualizados em rituais cuja função é de explicar o mundo e marcar o início de um novo ciclo. A escola, em particular a sala de aula, constitui-se no espaço propiciatório para que teoria e cultura operem no homem, humanizando-o, enquanto passam por um processo de transformação, a fim de que os seres humanos que ali estão, os estudantes, conheçam a gênese, as características elementares e os porquês que estruturam as teorias, a fim de compreender a si mesmos e o seu lugar no mundo.

Para que os sujeitos se apropriem do conhecimento teórico e da cultura produzida historicamente pela nossa espécie, não basta só que os conceitos sejam os mediadores da aprendizagem ou que exista uma sistematização intencional para mobilizar a atividade de estudo. Mais do que isso, os sujeitos precisam ser mobilizados a se interessar pelo conhecimento e compreendê-lo como meio essencial para entender seu lugar no mundo e na sociedade. Quando o sujeito está adequadamente mobilizado ${ }^{36}$ a conhecer o que é o conhecimento, está próximo de um princípio da filosofia, a saber, a curiosidade, o espanto, a admiração, como assevera Aristóteles,

[...] de fato, os homens começaram a filosofar, agora como na origem, por causa da admiração, na medida em que, inicialmente, ficavam perplexos diante das dificuldades mais simples; em seguida, progredindo pouco a pouco, chegaram a enfrentar problemas sempre maiores [...]. (ARISTÓTELES, 2002, p. 11, [982b]).

36 Delari (2020) contribui para a compreensão do sentido da palavra motivos ou mobilizar [no âmbito do senso comum] da esfera motivacional [os motivos ou a mobilização], pois são distintas no que concerne à Psicologia Histórico-Cultural, sobretudo em Vigotski, haja vista que a consciência, que compreende os interesses e impulsos, os afetos e emoções a partir da necessidade precisa conhecer que os motivos são "[...] forças motrizes de nosso comportamento variam em cada período etário e seu desenvolvimento determina as mudanças que se produzem no próprio comportamento [...]" (VIGOTSKI, 2006, p. 11). 
Desta feita, o piparote inicial da atividade filosófica é a admiração, o interesse, que pode ser tomado como um princípio dialético que precisa ser concomitantemente mobilizado e, para isso, não basta um conhecimento atraente ao escolar, longe disso, é preciso que o professor compreenda sua função social e tenha consciência de seu papel como sujeito que pode criar situações, que vivenciadas adequadamente, podem mobilizar a aprendizagem e o desenvolvimento dos escolares em estudantes.

A importância da transposição do conhecimento acadêmico para o que será o mediador em sala de aula, o fato de que não é qualquer tipo de conhecimento que é capaz de promover o desenvolvimento das funções psicológicas superiores, de que ele precisa antes estar intencionalmente organizado para isso e que o professor tem notável função para promover a aprendizagem e o desenvolvimento na adolescência, é algo que precisa ser desvelado pormenorizadamente, o que será feito adiante.

\subsection{A Formação da Consciência Crítica por meio da Atividade Filosófica}

A atividade filosófica, para integrar o corpo de atividades com a intenção de promover um ensino desenvolvedor (DAVIDOV, 1988) das funções psicológicas superiores, precisa ser engendrada a partir de um ensino da Filosofia, cuja intenção seja propiciar o desenvolvimento do pensamento conceitual e a formação da consciência crítica na vida objetiva dos escolares, transformando-os em estudantes (FREIRE, 2016).

No entanto, este não é um percurso fácil, haja vista que ele depende de múltiplos fatores para a sua operacionalização. Como predito, não bastam a admiração advinda da atividade filosófica e a necessidade de sobrelevar 0 conhecimento adquirido, por meio do senso comum, é preciso que o professor tenha consciência de sua função social, bem como da estrutura política e histórica dos sistemas de ensino para mobilizar a atividade de estudo na escola.

Destarte, incorpora-se Gramsci (2020) nesta pesquisa, pois para ele a escola é apresentada como um espaço destinado à conquista da cidadania, num 
contexto que pode mobilizar a transformação da consciência dos indivíduos. Gramsci $(1979,1986,2020)$, neste sentido, contribui para pensar os coletivos de estudo, haja vista que a apropriação da cultura acumulada sócio-historicamente é mediada pela relação do homem com a realidade concreta, por meio da relação com os outros homens, de tal forma que estes passassem a desejar a elevação cultural.

Segundo Gramsci (2000a, 2020), os processos de escolarização devem ocorrer, a partir de uma concepção dialética e revolucionária, porquanto para ele a escola é um poderoso instrumento estratégico, que possibilita não apenas o acesso à formação tradicional, mas, sobretudo, possibilita alçar o homem humanizado às máximas potencialidades da genericidade humana.

A escolarização para Gramsci (2000a), além de promover a apropriação da cultura elaborada sócio-historicamente ao proletariado, pode engendrar 0 movimento propício para que cada sujeito, submerso em seu contexto, possa se tornar um cidadão consciente de sua função, ou seja, o pensador italiano observa a potência de transformação que pode concernir e convergir ao ambiente escolar.

Para Gramsci (1979, 1986, 2000a), a escola que está a serviço do proletariado deveria formar os intelectuais orgânicos dentro da classe trabalhadora, sobretudo, centralizar seus esforços, substancialmente, naqueles que não tiveram oportunidade de estudos e, mais ainda, nos jovens, porquanto para ele o futuro e a história pertenciam aos jovens. Para além disso, a educação popular deveria ser universal, para emancipar os sujeitos do adestramento propiciado por um sistema educacional, que visa escolarizar para formar sua mão de obra e não intelectuais aptos a compreender sua realidade objetiva.

Assim, os jovens deveriam se armar adequadamente por meio do desenvolvimento da inteligência na instrução escolar, a fim de se apropriarem de instrumentos que thes permitam refletir e elaborar uma análise crítica do status quo. Gramsci (2020) assevera:

O futuro é dos jovens. A história é dos jovens. Mas dos jovens que pensam a tarefa que a vida impõe a cada um, que se preocupam em se armar adequadamente para resolvê-la da maneira que melhor convém às suas conviç̧ões íntimas, que se preocupam em criar para si aquele ambiente no qual sua energia, inteligência e atividade 
encontrem o máximo de desenvolvimento, a mais perfeita e frutífera afirmação (GRAMSCI, 2020, p. 19).

O processo de escolarização, para Gramsci (1979, 1986, 2000a, 2020), por conseguinte, não serviria apenas para uma formação tecnicista, amparando o mínimo de ler, escrever e contar, como é voltado um ensino que visa tão somente elevar um nível de proficiência a outro, tirando os sujeitos do abaixo do básico para o básico e assim por diante. Necessário é assinalar que não é bondade do Estado salvar os indivíduos da ausência do letramento, mas que o mercado impõe esta operação para que esses não atrapalhem a obtenção de lucros, pois seria um caos ter uma mão de obra objetivamente inoperante por não saber o mínimo; o letramento, desta feita, não é para ler o mundo criticamente, mas apenas para decifrar os códigos mínimos para a execução do adequado trabalho pelo proletariado (para operar o maquinário, atender 0 telefone para a venda de um produto, recepcionar o público, obedecer às normas da empresa, para ser um bom colaborador e afins).

Daí para Gramsci (2000a, 2020), o Estado deveria assumir uma educação popular, gratuita, mas não uma com a mesma eficácia das organizações de beneficência, que acreditam que "um prato de sopa pode satisfazer as necessidades fisiológica dos desgraçados que não podem se alimentar e despertam a piedade no tenro coração dos seus senhores" (GRAMSCI, 2020, p.72).

Gramsci $(1979,2000 a, 2020)$ pretendia convidar os jovens a enfrentar o desafio de apropriação dos meios de produção, da estrutura e da superestrutura $^{37}$, por meio de um ato de independência e liberação, mediado pela energia e inteligência. Contudo, o movimento é dialético. Não há como tomar o aparelho de Estado para produzir o novo homem, é preciso antes produzir o novo homem, o intelectual orgânico do e para o proletariado, para

\footnotetext{
${ }^{37}$ A superestrutura constitui o modo pelo qual as sociedades organizam suas normas, regras jurídicas e políticas, bem como as articulações educativas e culturais que legitimam e favorecem a reprodução das relações sociais correspondentes à base econômica da sociedade. Ela pode ser dividida em duas categorias: sociedade civil (o conjunto de organismos designados como privados, que garantem a hegemonia do grupo dominante sobre a sociedade) e sociedade política (o Estado, que cumpriria o papel da coerção por meio de seus aparelhos). Há, no entanto, aparelhos do Estado que não agem de forma completamente coercitiva, mas por meio do convencimento, estes conseguiriam garantir a hegemonia da classe dominante sobre os subalternos (proletariado), estes seriam os intelectuais da classe dominante (GRAMSCI, 1979, 2020)
} 
apropriação dos meios de produção, da estrutura e da superestrutura por meio do engajamento em um novo ambiente, no qual pudessem se combinar, resultando na mais perfeita e frutífera afirmação de luta contra a mais-valia.

É válido salientar que a mais-valia faz com que o proletariado tenha seu tempo livre diminuído, tempo este que poderia ser um campo profícuo para o desenvolvimento humano, até mesmo porque "o homem que não dispõe de nenhum tempo livre, cuja vida, afora as interrupções puramente físicas do sono, das refeições [...] está toda ela absorvida pelo seu trabalho para o capitalista" (MARX, 1985, p. 92-93).

O homem espiritualmente animalizado (GRAMSCI, 2000a), como se consegue depreender da leitura de Marx, torna-se uma besta de carga para produzir riqueza alheia, ficando para o grupo social com mais tempo livre, possuidor de riqueza econômica, o controle do poder cultural, político e econômico, subjugando àqueles que possuem pouco ou nenhum tempo livre. É por isso que é possível inferir, a partir do posto até então neste texto, que a dominação social é um reflexo da dominação econômica perpetuada pelo sistema capitalista.

Se a classe dominante por meio do sistema capitalista consegue formar seus intelectuais orgânicos para garantir a homogeneidade, sem necessariamente utilizar a coerção, para Gramsci (1979, 2000a), a classe dominada também precisaria formar os seus intelectuais orgânicos, pois 0 intelectual orgânico está organicamente ligado a uma determinada classe social, à sua luta. A partir disso, Gramsci conduz a reflexão de que a contradição social entre o grupo dominante e o grupo subalterno corresponde à forma como são organizados os sistemas escolares, como é possível identificar atualmente.

A escola seria, portanto, um aparelho de cultura de hegemonia que, para Gramsci (2000a, 2020), teria a função de passar às novas gerações toda a experiência do patrimônio do passado. Ele observa, no entanto, que dependendo do status quo, há uma escola de níveis diferentes, para classes sociais diferentes, e isso poderia ocorrer de forma velada ou explícita. A escola clássica seria a destinada para a formação dos ricos, enquanto a escola profissionalizante 
seria destinada para os pobres $^{38}$, o que, exatamente, é possível notar hodiernamente com a Reforma do Ensino Médio.

Segundo Gramsci (1979), portanto, deveria existir uma

A escola unitária ou de formação humanista (entendido este termo, 'humanismo', em sentido amplo e não apenas no sentido tradicional) ou de cultura geral deveria se propor a tarefa de inserir os jovens na atividade social, depois de tê-los levado a um certo grau de maturidade e capacidade, à criação intelectual e prática e a uma certa autonomia na orientação e na iniciativa (GRAMSCI, 1979, p.121).

A defesa da escola pública, laica e gratuita depende diretamente da manutenção do Estado. No Brasil, essa discussão foi iniciada ainda na década de 1930 com o Manifesto dos Pioneiros assinado por Anísio Teixeira, Afrânio Peixoto e Lourenço Filho, movimento este de cunho escolanovista. Contudo, ainda hoje, com a Reforma do Ensino Médio, esta discussão está longe de acabar, sobretudo, quando se incorpora a Pedagogia Histórico-Crítica e se procura afastar a escola do espontaneísmo e do construtivismo apregoado pelas atuais políticas públicas. Sobre a crítica gramsciana ao construtivismo, Gramsci assinala que

[a] escola criadora não significa escola de 'inventores e descobridores'; ela indica uma fase e um método de investigação e de conhecimento, e não um "programa" predeterminado que obrigue à inovação e à originalidade a todo custo. Indica que a aprendizagem ocorre notadamente graças a um esforço espontâneo e autônomo do discente, e no qual o professor exerce apenas uma função de guia amigável, como ocorre ou deveria ocorrer na universidade. Descobrir por si mesmo uma verdade, sem sugestões e ajudas exteriores, é criação (mesmo que a verdade seja velha) e demonstra a posse do método; indica que, de qualquer modo, entrou-se na fase da maturidade intelectual na qual se pode descobrir verdades novas. Por isso, nesta fase, a atividade escolar fundamental se desenvolverá nos seminários, nas bibliotecas, nos laboratórios experimentais; é nela que serão recolhidas as indicações orgânicas para a orientação profissional (GRAMSCI, 1979, p. 124-125, aspas do autor) ${ }^{39}$.

${ }^{38}$ Saviani (2003) assevera a respeito da escola dualista que esta é dividida conforme o sistema em que está submersa, respeitando a divisão social de classes, a burguesa e a proletária; o que de acordo com essa perspectiva, faz da escola um instrumento para impedir o desenvolvimento da ideologia da classe trabalhadora e sua luta revolucionária, colocando-a como aparelho ideológico da burguesia, a favor de sua hegemonia e contra o proletariado.

${ }^{39}$ Apesar desse pensamento ser atualmente utilizado pelas metodologias ativas no campo do construtivismo, sob a perspectiva do professor facilitador de aprendizagem, Gramsci (2020a, 2020b) em nenhum momento apoiou as metodologias ativas, o escolanovismo, o construtivismo e as teorias derivadas, ao contrário, fez severas críticas a estes tipos de teorias pedagógicas. 
Para Gramsci (2000a, 2020), o estudo deveria ocorrer com assistência do professor e dos melhores estudantes, mesmo nas horas de estudo individuais, ou seja, havia a priorização da atividade de estudo coletiva. Para além disso, Gramsci $(2000 a$, 2020) fazia a defesa do estudo desinteressado, porquanto todos os estudantes deveriam ter acesso à cultura e não necessariamente, logo de início, e direcionadamente a uma profissão, pois todos deveriam ter o direito de acesso à cultura universal. Retirar dos pobres o direito de acesso à cultura universal, sob o pretexto de encaminhar o jovem mais rapidamente para 0 mercado de trabalho é uma forma de perpetuar as contradições de uma sociedade desigual.

Se se quer destruir esta trama, portanto, deve-se não multiplicar e hierarquizar os tipos de escola profissional, mas criar um tipo único de escola preparatória [...] que conduza o jovem aos umbrais da escolha profissional, formando-o, durante este meio tempo, como pessoa capaz de pensar, de estudar, de dirigir ou de controlar quem dirige. A multiplicação de tipos de escola profissional tende a eternizar as diferenças tradicionais (GRAMSCI, 2020, p. 49).

Gramsci $(1979,1986,2020)$ já denunciava naquele período o que é possível ver hoje, de que

\begin{abstract}
o tipo de escola que se desenvolve como escola para o povo não tende mais nem sequer a conservar a ilusão, já que ela cada vez mais se organiza de modo a restringir a base da camada governante tecnicamente preparada, num ambiente social político que restringe ainda mais a "iniciativa privada" no sentido de fornecer esta capacidade e preparação técnico-política, de modo que, na realidade, retorna-se às divisões em ordens "juridicamente" fixadas e cristalizadas ao invés de superar as divisões em grupos: a multiplicação das escolas profissionais, cada vez mais especializadas desde o início da carreira escolar, é uma das mais evidentes manifestações desta tendência. (GRAMSCI, 1979, p. 137, aspas do autor).
\end{abstract}

Como supramencionado, o professor precisa ter consciência de sua função social, da história política e social da escola e de que processos como estes continuam atuais. O professor, ciente disso, precisa de alguma maneira conscientizar os seus, sejam os colegas de profissão, sejam os estudantes pelos quais são responsáveis. Evidentemente que este movimento não acontece espontaneamente, mas é mediado pelo conhecimento teórico e pelas relações inter e intrapessoais na escola, as quais precisam construir um ambiente 
favorável para a apropriação da cultura elaborada sócio-historicamente (VIGOTSKI, 2000a).

O pressuposto fundamental de um ensino norteado pela teoria marxiana é que a função principal da escola é a socialização do conhecimento elaborado sócio-historicamente, desde que o ensino esteja intencionalmente orientado para a objetivação $0^{40}$ da aprendizagem e do desenvolvimento. Para isso, a atividade pedagógica e a atividade filosófica, devidamente organizadas com a finalidade de transformar o psiquismo dos estudantes, podem transformar a relação dos sujeitos envolvidos, com os processos de escolarização, com o conhecimento teórico, seus símbolos, signos e o seu significado, necessariamente integrado à produção genérica humana, ao universal ${ }^{41}$.

Os sistemas de ensino tais como estão e são organizados não permitem aos sujeitos este movimento e negar o acesso ao conhecimento filosófico, por exemplo, só corrobora isso. Toda vez que um sistema de ensino nega aos indivíduos o acesso a um determinado tipo de conhecimento, que poderia estar em um componente curricular, como predito, não se constitui apenas em algo contraditório, pensando na oferta de uma formação integral, mas também aponta uma intenção e ela é declarada, quando certos componentes saem da grade curricular ou tomam outra forma.

Daí, advém a percepção de que a atividade filosófica só possa ser mediadora de transformações, quando privilegia a apropriação do conhecimento teórico-filosófico, por meio de condições que integrem a afetividade, a volição e a vivência dos indivíduos, considerando as especificidades de desenvolvimento dos escolares. Algo que as políticas públicas da Secretaria da Educação do Estado de São Paulo têm precarizado há décadas, cada vez mais, nas escolas públicas da rede estadual.

Gramsci (1979, 1986, 2020a, 2020b) aponta que os processos de escolarização possuem uma dimensão estratégica quando não são pensados para sobrelevar o pensamento, muitas vezes cristalizado, de que só pode se

\footnotetext{
40 De acordo com Hamada (2015, p.10), objetivação é uma efetivação de algo ou situação nova resultante da conexão entre teoria e prática e, portanto, modificadora da realidade material.

${ }^{41}$ Universal no sentido de que a "[...] a singularidade se constrói na universalidade e, ao mesmo tempo e do mesmo modo, [...] a universalidade se concretiza na singularidade, tendo a particularidade como mediação", conforme assevera Oliveira (2005, p. 26).
} 
alçar à apropriação do conhecimento teórico, ou pertencer à camada dos intelectuais, ou ainda ser filósofo os indivíduos que pertencem à classe dirigente $^{42}$, porque são estes que detêm a hegemonia ${ }^{43}$ do Estado (sociedade civil mais sociedade política) e inclusive criam um bloco ideológico ${ }^{44}$.

Como supradito, Gramsci $(1979,1986,2020)$ pensa a escola como um dos projetos que podem conduzir à formação de um novo bloco hegemônico ${ }^{45}$. Nesse sentido, Gramsci não acreditava em uma "tomada" de poder que não fosse antecedida por transformações nas formas de compreender a sociedade e por mudanças significativas em sua mentalidade.

Segundo este autor os principais agentes dessas transformações seriam os intelectuais e um dos seus instrumentos mais importantes é a escola. Desta forma, promover a apropriação do conhecimento teórico pelo proletariado, que na sociedade capitalista está à margem de se alçar à genericidade humana, é possibilitar, para além de condições dignas, no que concerne a formação de cidadãos, o contexto propiciatório para a formação de um novo bloco histórico ${ }^{46}$.

Se, conforme assevera Gramsci, "todos os homens são intelectuais" (GRAMSCI, 2000a, p. 18), é adequado promover às classes subalternas condições que possibilitem que estas se apropriem de signos, símbolos, sentidos e significados da mais alta cultura, elaborada sócio-historicamente, e para que elas possam formar seus próprios intelectuais, com o propósito dela mesma construir, a partir de suas necessidades, um novo bloco hegemônico.

Seguindo esta tese, a escola está para servir os princípios dados pela classe dominante, que produziu em seu seio seus próprios intelectuais orgânicos. Assim, a hegemonia é mantida pela classe burguesa e seus

\footnotetext{
${ }^{42} \mathrm{~A}$ classe dirigente não só justifica e mantém o domínio, mas consegue obter o consentimento ativo dos governados. Nisso os intelectuais orgânicos têm importante função, pois são os responsáveis por unificar os indivíduos em torno da visão de mundo que lhe é própria, visando garantir o poder. A classe dirigente também pode ser dominante e isso ocorre quando passa a deter as ferramentas para controle político, econômico e social (PORTELLI, 1977).

${ }^{43} \mathrm{~A}$ hegemonia é domínio ideológico dos valores e normas da classe dominante, ou aspirante ao domínio, sobre as classes subalternas.

${ }^{44}$ De certa forma o bloco ideológico pode ser formado pelos intelectuais orgânicos que elaboram formas de autoridade e coerção que envolvem artifícios sofisticados de controle, assim, esta parte do bloco seria responsável por orientar as necessidades das classes subalternas.

$45 \mathrm{O}$ bloco hegemônico integra todas as classes sociais em torno de um único projeto, seu poder combina e articula a coerção e o consenso.

${ }^{46}$ Com o conceito de bloco histórico, Gramsci se refere a um conjunto de forças sociais em que a estrutura econômica encontra correspondência com a ideologia das classes dirigentes e dominantes.
} 
intelectuais, porquanto são eles os responsáveis pela dominação e direção tanto no campo da ética, quanto no da política, por moldar os indivíduos, suas práticas e necessidades à imagem e semelhança da classe dominante por meio da estrutura e superestrutura ${ }^{47}$.

Assim sendo, a escola pode servir como um poderoso instrumento de formação de uma classe intelectual oriunda das classes subalternas para a promoção de uma práxis revolucionária (VÁZQUEZ, 1977). Entretanto, para isso acontecer, é preciso um ensino intencionalmente organizado a fim de desenvolver as funções psicológicas superiores e propiciar a apropriação de noções instrumentais tais como ler, escrever, reconhecer os conceitos científicos, fazer contas, elaborar argumentos e, evidentemente, a partir disso, promover o desenvolvimento da linguagem e de um pensamento crítico e consciente e, nesse aspecto, a afetividade pode colaborar significativamente.

Neste sentido, os indivíduos que compõem o corpo escolar podem organizar ações e operações que colaborem para evocar nas classes subalternas a necessidade de se apropriar do conhecimento teórico.

Na presente pesquisa, a Filosofia é vista como um meio que possibilita, dialeticamente, a formação de uma leitura diferente do mundo, para a constituição de novas formas de pensar a realidade concreta e isso não se dá apenas com os jovens da pesquisa, mas também na constituição profissional e pessoal desta professora que também teve a sua consciência e o exercício da práxis de sua função radicalmente impactados.

A educação escolar pensada pelos princípios da teoria marxiana tem a função, ao desenvolver as estruturas psicológicas superiores, de orientar 0 aspecto afetivo do escolar, seus motivos e sentidos na atividade pedagógica e filosófica, de maneira a conduzi-lo para sua atividade principal ${ }^{48}$, rompendo com os processos alienadores da sociedade de classes, que fragmentam tais relações.

\footnotetext{
47 Gramsci considera que estrutura (as relações sociais de produção) e superestrutura (as ideias, os costumes, os comportamentos morais, a vontade humana) realizam na realidade concreta um movimento de interseção, apesar de dialeticamente possuírem distinções.

48 Conforme Leontiev (2004, p. 312), a atividade principal ou dominante é "[...] aquela cujo desenvolvimento condiciona as principais mudanças nos processos psíquicos da criança e as particularidades psicológicas da sua personalidade num dado estágio do seu desenvolvimento".
} 
Para isso, a educação escolar pode ser vista como ponto de partida de um processo potencializador do desenvolvimento e que pode impulsionar as relações entre o sujeito singular, o conhecimento da cultura historicamente acumulada e a atividade que ele pode realizar de modo consciente em direção à genericidade humana, o universal. Esse movimento pode ser produzido pela integração entre a atividade pedagógica e a atividade filosófica, engendrando possibilidades para impactar os estudantes profundamente em suas esferas objetivas e subjetivas da vida, inclusive para além dos muros escolares.

Todavia, como já foi dito reiteradas vezes, não é qualquer tipo de ensino que possibilita o desenvolvimento e a transformação das funções psicológicas superiores dos estudantes, ainda mais quando a intenção é impactar a consciência de maneira a promover a formação da criticidade no ambiente escolar. Este processo é complexo, cheio de crises e caótico.

O principal guia textual para compreender este processo e o período etário estudado, a saber, a fase de transição da adolescência, é a Paidología del Adolescente de Vigotski (2006), que apresenta como se desenvolvem os interesses, o pensamento conceitual, abstrato, dialético e crítico no adolescente.

Segundo Vigotski (2006, p.11, tradução nossa) "o problema do interesse na idade de transição é a chave para entender todo o desenvolvimento psicológico do adolescente", pois é ele a força motriz que faz o indivíduo se sentir mobilizado a realizar determinadas coisas e não outras. Afinal de contas, todos os mecanismos do pensamento, da atenção e da memória são diferentes no adolescente, o que significa que 0 desenvolvimento destes está mais intimamente vinculado com a coletividade, com o meio social, do que com a formação biológica que era prevalecente na infância.

Não que a base biológica não tenha importância neste período. De acordo com a teoria vigotskiana, a integração, entre fisio e ontogênese, é como o traçado de linhas paralelas, que ora se cruzam, ora se distanciam. Na adolescência, sempre que há a maturação de uma nova base biológica há também o desenvolvimento de novos interesses. $E$ este desenvolvimento não se dá de forma linear e cadenciada, mas ao contrário, por movimentos arrítmicos.

De forma quase que poética, Vigotski (2006) nos aponta que é a integração entre a linha do desenvolvimento dos interesses e a linha do desenvolvimento dos mecanismos do comportamento, na adolescência, que 
pode direcionar a volição e a atenção para um único sentido, na mobilização/direcionamento das necessidades e dos sentidos:

[...] usando uma comparação figurada, os processos de desenvolvimento na infância e na idade de transição frequentemente lembram a transformação da lagarta em crisálida e da crisálida em borboleta. Neste processo de desenvolvimento, antes da mudança qualitativa das formas, antes do aparecimento de novas formações, o próprio processo revelou claramente a sua estrutura complexa, esta é composta pelos processos de extinção, desenvolvimento inverso ou redução da forma antiga e dos processos de nascimento, formação e maturação da nova forma. A transformação da crisálida em borboleta pressupõe tanto a extinção da crisálida quanto o nascimento da borboleta; toda evolução é, ao mesmo tempo, involução (VIGOTSKI, 2006, p. 24-25, tradução nossa).

Assim, quando no adolescente surgem novos interesses, desaparecem os antigos, "[...] ele não só começa a se interessar por objetos que the são completamente novos, mas também perde interesse por coisas que the interessavam antes" (VIGOTSKI, 2006, p.25, tradução nossa). O que é deveras intrigante, posto que, se na fase anterior, na infância, sua atividade principal era a atividade de estudo, na adolescência, a atividade principal passa a ser a atividade de comunicação íntima-pessoal (ELKONIN, 1987). Desta maneira, o estudo pode deixar de ter grande destaque em sua vida.

$\mathrm{Na}$ atividade de comunicação íntima-pessoal, o adolescente estabelece "[...] relações com os seus pares, com base em certos padrões morais e éticos que medeiam" (ELKONIN, 1987, p. 120-121, tradução nossa) suas ações, e esse fato faz com que ela mude a postura do jovem em relação à forma como ele enxerga o outro e a sociedade. A marca principal deste período é que o jovem passa a buscar na coletividade, inicialmente, a que ele pertence, certo reconhecimento e a apresentar certos posicionamentos, diante do que pessoalmente the incomoda.

Segundo Elkonin (1987, p. 120, tradução nossa), observa-se assim a subordinação das relações a um "código de companheirismo" em que "[...] as relações podem ser estabelecidas e são definidas não só com base no respeito mútuo, mas também em uma completa confiança [...]”. Elkonin (1987, p. 121, tradução nossa) assevera que "a comunicação pessoal constitui aquela atividade dentro da qual se formam os pontos de vista gerais sobre a vida, sobre as 
relações entre as pessoas e com o próprio futuro; em uma palavra, se estrutura o sentido pessoal da vida".

Destarte, a comunicação íntima-pessoal confirma o que já havia sido dito por Vigotski reiteradas vezes, bem como pela teoria marxiana: a forma superior do desenvolvimento advém das relações coletivas que poderão ser voltadas para as máximas possibilidades humanas, dadas pela cultura elaborada sóciohistoricamente.

Por outro lado, esta alteração de atividade principal traz desafios para a educação escolar, sobretudo, com relação à formação e ao desenvolvimento de funções psicológicas superiores tão complexas, como o pensamento por conceitos e a consciência crítica.

Se neste período, considerando a atividade de comunicação íntimapessoal, o jovem volta seu interesse para conhecer a si e ao seu coletivo, considerando a sua função nesta coletividade, seus interesses e desejos em relação aos demais e ao que este meio pode the oferecer, a educação escolar precisa reputar um ensino que leve em conta esta condição.

É válido salientar que, assim como o contexto escolar é caótico e contraditório, é preciso também sopesar que o desenvolvimento na adolescência ocorre por meio de movimentos arrítmicos e caóticos. À vista disto, o professor pode lançar mão de instrumentos que integrem a atividade pedagógica à atividade filosófica, com a finalidade de criar mecanismos que orientem 0 desenvolvimento do pensamento, por conceitos, para que este opere de maneira abstrata, dialética e crítica (analítica). Porém, isso só acontece quando o professor tem esta intencionalidade e isso depende do quão consciente é de sua função.

Segundo Vigotski (2006), esse movimento contraditório é a condição do desenvolvimento desta fase, em que a condição da forma de pensamento na adolescência é a contradição, ou seja, o conteúdo de seus pensamentos é a contradição. Portanto, esta é uma fase permeada por desdobramentos desenvolvimentais em pólos opostos em que os pensamentos dos jovens ora pendem para um certo romantismo ideológico, ora para uma intensa atividade lógica (VIGOTSKI, 2006, p. 67-68, tradução nossa).

Vigotski (2006, p.24) assinala que também é na adolescência que a relação entre o objetivo e o subjetivo faz produzir transformações nos sistemas 
internos das necessidades e que Bühler já alertava que esta fase também é caracterizada pela desaparição dos interesses escolares. $\mathrm{O}$ que aponta para o que fora supramencionado: de que quando surgem novos interesses, desaparecem os antigos.

Isso tudo porque nesse período tudo está acontecendo. Redundante? $\mathrm{Na}$ prática da sala de aula isso é possível de se perceber, com uma análise atenta, sobretudo, na educação básica, quando há a transição, ou melhor, a alteração abrupta de experiência escolar do Ensino Fundamental II para o Ensino Médio, em que novas relações são estabelecidas, novos critérios avaliativos são impostos e surgem inúmeros componentes curriculares, antes desconhecidos.

A experiência desta professora aponta que a personalidade da criança aos poucos vai transitando e, no adolescente, como poderá ser examinado no capítulo que apresenta a intervenção didático-pedagógica, se misturam características do passado (a atividade de estudo) com as atuais (a atividade íntima-pessoal). Para Vigotski (2006), esta transformação, assim como todas as outras (as precedentes e as posteriores) precisam ser acompanhadas de maneira minuciosa.

Isso ocorre porque, se a atividade de estudo, que antes era prevalente, cede lugar a outra que muda completamente o seu foco, estes estados chamados de provisórios, que produzem crises, desorientação e caos, podem extinguir no futuro as possibilidades de o jovem conseguir integrar à sua atividade principal uma secundária que seja organizadora destes estados caóticos e contraditórios. Segundo Vigotski (2006, p.35-36), estes sintomas podem ser agudizados consideravelmente se houverem falhas pedagógicas, e é o que se tem observado: muitos consideram a adolescência uma simples e linear continuidade do desenvolvimento anterior.

A adolescência, portanto, se mostra como uma etapa que não é homogênea e que inclusive a própria maturação social pode desenvolver por si mesma a reestruturação da personalidade e destes interesses. A escola, neste processo, pode contribuir, quando orienta o conteúdo do pensamento, reestruturando-o por meio da formação de conceitos, haja vista que "o pensamento por conceitos abre diante do adolescente o mundo da consciência social objetiva, o mundo da ideologia social" (VIGOTSKI, 2006, p. 64, tradução nossa). 
E aqui se chega a um ponto crucial, a possível integração entre uma atividade passada à atual vinculando-a à próxima, uma vez que quando o adolescente consegue aprender a pensar por conceitos, consegue provisoriamente colocar nos trilhos todo este caos arrítmico. A partir do momento em que 0 adolescente consegue ter o domínio e o interesse para aprender e se apropriar do conhecimento, a comunicação íntima-pessoal é orientada para um lado: o da aprendizagem, o da formação da consciência crítica.

Todavia, este é um processo dialético, posto que para realizar este movimento o jovem precisa antes ter a formação e o desenvolvimento do pensamento por conceitos e, para pensar por conceitos, ele precisa ser mobilizado em direção a uma atividade intencionalmente orientada para isso.

É desta maneira que se tem que o conhecimento teórico como mediador da atividade pedagógica integrada à atividade filosófica, pode possibilitar ao estudante ter a formação e o desenvolvimento do pensamento por conceitos de modo consciente, pois, neste tipo de atividade, há a intencionalidade de conduzir o estudante à gênese do conhecimento teórico.

De acordo com Vigotski (2006), o desenvolvimento do pensamento por conceitos, meio necessário para a formação da consciência, está integrado à apropriação da significação do conhecimento teórico. A apropriação dos nexos internos do conhecimento teórico elaborados sócio-historicamente favorece a compreensão do modus faciendi humano na elaboração da cultura e colabora com o desenvolvimento das funções psíquicas superiores dos estudantes.

E neste processo que o indivíduo pode se apropriar de forma a reproduzir o movimento substancial de constituição e desenvolvimento do conceito no decurso da história da humanidade em sua própria atividade, ou melhor, o estudante se apropria do objeto do conhecimento internalizando as principais características humanas e culturais que marcam historicamente este objeto, o seu modus faciendi (FREIRE, 2016).

Durante esta reprodução o jovem tem a possibilidade de realizar em sua atividade de estudo a atividade encarnada ontogeneticamente no objeto. Isso se dá de maneira adequada (mas não idêntica), se formos considerar que todo conhecimento teórico e científico tem um padrão de abstração, que precisa passar por certa transposição, para ser elemento mediador na vida escolar do jovem do Ensino Básico. 
E é na atividade pedagógica integrada à atividade filosófica mediante ações de ensino e de estudo produzidas nesse processo, que podem ser favorecidas para a transformação do pensamento empírico, processo necessário para entender a realidade concreta e as características externas dos objetos, em pensamento por conceito, na apropriação das características essenciais dos objetos do conhecimento escolar.

Isso não significa, no entanto, que só basta orientar o adolescente que uma mágica ocorre ao longo do processo, mas que, quando há a adequada e intencional mobilização de hábitos e de conduta, os interesses e necessidades dos jovens podem ser utilizados como meio do processo educativo. Afinal de contas, toda e qualquer incitação aos hábitos, interesses e volições dependem de como são formados e direcionados para determinadas necessidades e sentidos, porquanto as atrações são formadas culturalmente e que "a forma superior da necessidade humana é uma forma histórica" e coletiva (VIGOTSKI, 2006, p. 22, tradução nossa).

O objetivo da educação, de acordo com Vigotski (2006, p. 38), consiste em formar determinados interesses, que se configuram em interesses fundamentais para a vida seguinte do adolescente. Vigotski ainda pondera que estes interesses e o processo de desenvolvimento dos jovens é diferente entre adolescentes burgueses e os que pertencem ao proletariado. Vigotski (2006) cita as análises de Zagorovski que indicam que, neste último grupo, a adolescência começa tardiamente e acaba antes, quando comparado ao primeiro grupo. $\mathrm{O}$ que faz pensar que é a relação social que o adolescente possui com sua classe, bem como a consciência que possui desta, que pode alterar a sua concepção de mundo político-social, suas concepções pessoais, suas aspirações e volições [este último lexema no sentido vigotskiano, a saber, escolhas].

Tem-se assim, que é na integração entre a atividade de ensino e a atividade de estudo, promovidas durante o decurso da atividade pedagógica, entendida esta como unidade dialética, enquanto instrumentos que norteiam e a atividade filosófica, tendo em vista a constituição da práxis pedagógica no contexto escolar, que se criam possibilidades de transformar efetivamente a realidade concreta e, assim, promover a apropriação, a formação e o desenvolvimento do pensamento por conceitos e a consciência crítica. 
Conforme Freire (2016, p. 15), "na teoria marxiana, essa dimensão contempla a práxis transformadora, atividade conscientemente orientada com a intenção de integrar teoria e prática na transformação não apenas das dimensões objetivas, mas também subjetivas da atividade". E este movimento, sendo dialético, vai solicitar do professor também um tipo específico de atividade de ensino, que contemple e impacte tanto os aspectos cognitivos quanto os afetivos e os volitivos.

Por conseguinte, a atividade filosófica que incorpora em sua práxis a atividade pedagógica pode contribuir para a formação e o desenvolvimento da consciência crítica dos estudantes, na mediação do conhecimento teórico. Entretanto, há a necessidade de se valer de instrumentos e mecanismos que considerem a integração do cognitivo com 0 afetivo e 0 volitivo, pois, sem considerar a unidade entre estes elementos, não há como haver efetivamente a formação de uma consciência crítica humanizada e humanizadora.

Desta feita, sabe-se pela teoria vigotskiana que a consciência se forma a partir da apropriação do significado do conhecimento sócio-historicamente elaborado, como reflexo da realidade objetiva. A sociabilidade se apresenta, portanto, como fator determinante para a objetivação do comportamento humano no homem e é desse processo que depende o desenvolvimento cultural (VIGOTSKI, 2006), uma vez que a dimensão orgânica e/ou biológica é impregnada pela cultura e marcada pela história.

Para Vigotski (2006, p. 66 e 64, tradução nossa) "a mente do jovem se sente mais disposta ao concreto" e, concomitantemente, este concreto, "o conhecimento, a ciência, a vida cultural só podem ser adequadamente assimiladas, mediante a apropriação de conceitos". É por meio dessa apropriação que o adolescente transita por um caminho de desenvolvimento permeado por crises e saltos qualitativos, como nas outras fases, quando adequadamente orientadas e mobilizadas.

É por isso que o ensino deve conduzir o estudante adolescente aos meios superiores de compreensão, passando das manifestações externas dos objetos para as abstrações e, por conseguinte, às generalizações dos conteúdos estudados. Isso ocorre, tendo em vista que a mudança do conteúdo do pensamento no adolescente precisa perpassar por sua realidade interna e externa, como supramencionado. 
O ensino da Filosofia pensado como componente curricular pela perspectiva da Psicologia Histórico-Cultural, que integra atividade pedagógica à atividade filosófica como mediadora do ensino (e vice-versa), pode impactar, para além da formação do pensamento por conceitos, a formação da consciência crítica e das vivências. Vivências essas que são a unidade integradora entre a consciência crítica, a afetividade e a volição, ponto que será visto a seguir.

\subsection{A Atividade Filosófica na Unidade Dialética entre Cognição, Afetividade e Volição}

Os processos de desenvolvimento pelos quais os adolescentes passam, os fazem entrar em contato com o seu mundo interno, bem como com partes das funções psicológicas superiores que ainda estão em movimento de elaboração. Vigotski (2006) aponta que com

[...] a maturação e a aparição de atrações novas e necessidades internas que ampliam infinitamente o círculo de objetos que possuem força incitadora sobre os adolescentes, como esferas inteiras de atividade, antes neutra para eles, agora se tornam momentos fundamentais que determinam sua conduta, pois, junto com o novo mundo interno, surge para o adolescente um mundo externo completamente novo. (VIGOTSKI, 2006, p.24, tradução nossa).

É por isso que este período possui o que Vigotski (2006) denominou por desenvolvimento intenso, caótico e contraditório, cujo produto é mover o jovem para a próxima atividade e fase de desenvolvimento. Mas, para isso acontecer, seria necessária a ajuda de seus coetâneos e/ou de adultos com esta intencionalidade.

Evidentemente que, dentro do sistema educacional e em sociedade, o jovem pode chegar a ambas. O ponto aqui é a qualidade deste desenvolvimento, desta atividade e das funções psicológicas superiores. A intenção, por conseguinte, é emancipar o jovem, tornando-o crítico, capaz de ver o mundo com seus próprios olhos, de forma a conseguir distinguir conscientemente entre 0 momento de exigir o cumprimento de seus direitos ou a execução de seus deveres. Esta é a autonomia que almeja a Psicologia Histórico-Cultural. 
Se a atividade de comunicação íntima-pessoal, enquanto atividade principal deste período, considera a coletividade, como supramencionado, e se o desenvolvimento próximo depende de um movimento de auxílio do outro, é válido salientar que a formação do pensamento por conceitos, também depende desta contribuição externa, oriunda do mais experiente, que mobiliza ações e operações para uma determinada apropriação. E é a formação e o desenvolvimento deste tipo de função psicológica superior que poderá contribuir para a formação e o desenvolvimento do pensamento abstrato, dialético, crítico e consciente, necessários para a emancipação e autonomia do jovem.

A função de formação do pensamento por conceitos na idade da adolescência "desempenha um papel decisivo, pois permite ao adolescente entrar em contato com sua realidade interna e com suas próprias vivências", conforme indicado por Vigotski (2006, p. 71, tradução nossa). Destarte, 0 pensamento por conceitos e a apropriação da significação do conceito, assim como o próprio conceito são os elementos que tornam o pensamento claro, compreensível e objetivo,

[...] e é então que o adolescente começa a realmente se entender, a entender seu mundo interior. Sem ele, o pensamento não pode ser lúcido, não pode se tornar um conceito. Sendo um meio muito importante de conhecimento e compreensão, o conceito modifica substancialmente 0 conteúdo e 0 pensamento do adolescente (VIGOTSKI, 2006, p. 71, tradução nossa).

Assim, considerando que as funções psicológicas superiores se constituem neste período por apropriações conscientes dos meios culturais e considerando que as vivências são o processo e produto da formação e do desenvolvimento dessas funções, a reestruturação das relações sociais e da relação do jovem com a escola se dá por meio da apropriação da cultura e dos conceitos.

Este processo só é possível quando há uma atividade de ensino tal que medeie a compreensão do significado ontológico dos objetos e das coisas. Por isso, nesta pesquisa é tão cara a unidade dialética entre a atividade pedagógica e a atividade filosófica, porquanto não há como separar, ou melhor, fragmentar a constituição da consciência e da personalidade e tê-las como independentes da integração entre a cognição, a afetividade e a volição, e estas atividades 
consideram os indivíduos em sua integralidade, diversidade, especificidade e caoticidade.

Deste modo, a volição aqui entra no sentido vigotskiano, de decisão, de escolha, daí a importância da orientação de interesses e de ter em conta a afetividade dos sujeitos. Conforme Vigotski (2006), os interesses podem indicar quais são as necessidades na fase da adolescência e isso inclui também as necessidades de estudo, tendo em vista que o desenvolvimento próximo e a atividade próxima estão vinculadas à vida adulta.

Mesmo que a atividade de estudo não seja mais sua atividade principal, isso não significa que os jovens não possuam desejos no universo do conhecimento, muito pelo contrário, é só preciso descobrir qual é, ou qual pode ser o piparote inicial, para mobilizar o estudo na escola. Por que sua atividade principal é outra, se faz necessário que a educação escolar compreenda que a vida emocional do jovem pode ser impactada, redirecionada, transformada.

É na apropriação do conteúdo teórico que há apropriação de sentidos particulares acerca de cada coisa que é conhecida ou com a qual o se relaciona ou pode vir a se relacionar. A escola, desta maneira, deve ser um campo aberto de possibilidades, de modo que o jovem consiga ver no futuro motivos para decidir se apropriar da cultura elaborada sócio-historicamente, transposta pelos conteúdos escolares.

É o conceito que pode provocar as primeiras alterações nos motivos que impactam as formações de novas necessidades, contudo, sem uma bravo ou brava cavaleira, neste vasto campo, que decida travar esta árdua luta, contra as contradições de um sistema, de uma sociedade, de um Currículo, que decida deslindar com afeto o caos da adolescência, não há referencial teórico, tampouco componente curricular que sustente sua batalha. Seu escudo é sua consciência de classe, haja vista que consciente de sua função tem como dever se lançar na luta por conquistar processos de escolarização que transformem os estudantes em sujeitos autônomos, críticos e afetivos para com sua classe social.

Assim, a volição desta cavaleira, integrada à afetividade, à cognição e às vivências, não necessariamente nesta ordem, fizeram com que ela tentasse provocar a emersão, em um grupo de jovens, da transformação de suas consciências, porém, este ainda não é o momento de tratar disso. 
Com valentia e um tanto de temeridade, a categoria vivência será abordada neste texto. De acordo com Vigotski (2006), as vivências são a representação e a expressão do movimento que se desenvolve, na mediação das experiências acumuladas, a partir da atividade consciente, do interno com o externo e vice-versa, sintetizada na produção e compreensão de signos, símbolos, significados e da linguagem.

A vivência é a unidade da consciência e da personalidade, que se aprofunda por meio da formação do pensamento por conceitos (BEATÓN, 2017). Portanto, quanto maior for a qualidade dos conceitos que $\mathrm{O}$ adolescente apreende, quanto mais consegue conhecer sua realidade interna, seus interesses e desejos, mais ele conseguirá comunicar de melhor forma o que são, como são e quais são as maneiras possíveis de satisfazer suas necessidades e até mesmo ter e expressar um maior domínio de conduta.

Deste modo, a apropriação dos conceitos teóricos, dos signos, símbolos e significados, da cultura elaborada sócio-historicamente transposta no currículo escolar, como predito, não se reduz tão somente à formação e ao desenvolvimento do pensamento por conceitos, mas se assenta em uma relação interfuncional das funções psicológicas superiores. Isso assinala que as interações que ocorrem na vida interna do sujeito, a sua causa, advém da significação das coisas e que as afetividades, as emoções, os interesses e a volições, como parte da atenção e da percepção, participam deste complexo, são formadas, desenvolvidas e orientadas neste processo multifacetado e dialético, sendo assim também, funções psicológicas superiores.

Para além disso, é esta apropriação da significação das coisas, da cultura elaborada sócio-historicamente, que pode contribuir para o domínio da conduta e para a formação da atenção voluntária na vida do adolescente. Ambas as movimentações são de suma importância na vida escolar, a fim de promover algumas ações na práxis pedagógica no que diz respeito à atividade de estudo, por exemplo, haja vista que, sem o domínio de conduta, sem a reorientação de necessidades, sentidos, interesses e volições, não há aprendizagem e desenvolvimento, segundo a Psicologia Histórico-Cultural.

Sim, a apropriação do conhecimento teórico é um dos elementos principais que conduzem ao desenvolvimento das funções psicológicas superiores. E é este processo que acaba por desencadear o impacto positivo 
nos interesses, no comportamento, na afetividade e nos desejos dos indivíduos, apesar de isso causar certo estranhamento, à primeira vista.

A história da Velha Psicologia, como poderia dizer Vigotski (2004a), colocou as emoções e a afetividade como funções primitivas, animalescas, instintivas. No entanto, Vigotski (2004a, 2006) mostra que estas são, em verdade, funções superiores qualitativamente abstrusas, porquanto o seu funcionamento depende de um emaranhado de funções das elementares às superiores.

Por outro lado, são as afetividades, as emoções, os interesses e as volições que também abrem espaço para a apropriação do conhecimento teórico. Como assevera Vigotski (2006, p. 299, tradução nossa), "o afeto é o alfa e o ômega, o primeiro e o último elo, o prólogo e o epílogo de todo desenvolvimento psíquico".

As vivências, desta maneira, têm importante função nos mecanismos para o desenvolvimento das funções psicológicas superiores na idade da adolescência, haja vista que os adolescentes passam a enxergar de forma especial este tipo de episódio psicológico. Segundo Toassa (2009), "as vivências englobam tanto a tomada de consciência quanto a relação afetiva com o meio e da pessoa consigo mesma, pela qual se dispõem, na atividade consciente, a compreensão dos acontecimentos e a relação afetiva com eles".

Assim, a vivência tem profunda conexão com a afetividade e com a cognição, pois ela é, em suma, a forma como a realidade concreta afeta os indivíduos, a partir do que são (de suas histórias, de suas experiências, de suas relações), que há um tipo de apropriação dos conceitos, que o indivíduo tem uma maneira particular de se envolver com o conhecimento e com o estudo.

Uma das funções da escola é utilizar-se de instrumentos mediadores para propiciar uma mediação equitativa do conhecimento teórico, para que diferentes pessoas tenham a possibilidade de se alçar às máximas possibilidades da genericidade humana. Daí que é preciso que a escola passe também a ser espaço aberto, para o estudo dos fenômenos que nela ocorrem e que considere a realidade concreta dos estudantes, a constituição familiar de cada um deles, a forma como esta família interpreta os estudos na sociedade hodierna, as condições socioeconômicas em que se encontram, pois tudo isso impacta, e muito, no modo como o jovem pode priorizar ou não sua escolarização. 
Alguns desses elementos podem até não ser da governabilidade da escola (equipe gestora, funcionários, corpo docente), porém, em meio a uma crise econômica, a família pode condicionar a permanência do estudante na escola, para que ele tenha determinadas chances no mercado de trabalho, por causa dos estudos, ou exija sua imediata saída, pois a escola neste caso poderia ser um empecilho para seu ingresso no mercado de trabalho, independentemente do posto de trabalho.

As vivências, neste contexto, apontam que o outro e a forma como ele afeta o sujeito [adolescente] fazem emergir fenômenos que se constituem como pontes fundamentais ontológica e fisiologicamente para seu desenvolvimento. Isso se dá porque a maneira como este sujeito se sente em relação a essas influências e às suas possibilidades de elaboração são inúmeras.

Por isso, se não há o adequado acompanhamento dessas possibilidades, para além do adolescente perder certas oportunidades de formação e desenvolvimento que Ihes serão caras na vida adulta [pela organização do sistema capitalista], isso pode lhe custar a formação de sua própria visão de mundo [autônoma e emancipada].

Este é um movimento dialético, em que ora se sobressai o cognitivo na apropriação do conhecimento teórico filosófico, ora se evidenciam os interesses, a afetividade e a volição, como mediadoras das atividades acima mencionadas. $\mathrm{Na}$ adolescência, para a mobilização deste processo, é preciso organizar um ensino específico, capaz de integrar funções que se desenvolvem paralelamente de forma caótica, arrítmica e contraditória, a fim de propiciar ao jovem meios para que passe a tentar se conhecer e conhecer o seu meio de maneira consciente, analítica, crítica e aprofundada.

Como predito, a atividade filosófica integrada à atividade pedagógica, como mediadora de ações que contribuem para a compreensão das vivências na integração do cognitivo ao afetivo e ao volitivo, podem colaborar para a transformação do estudante em um jovem, cuja consciência crítica é capaz de analisar a realidade concreta, no processo de apropriação do conhecimento teórico filosófico, a fim de que ele possa tomar suas decisões conscientemente.

Assim, as relações, seguindo o processo de integração da atividade filosófica com a atividade pedagógica, se estabelecem como interfuncionais, porquanto buscam reputar verdade à cognição e à emoção, como meios que 
podem promover uma aprendizagem na escola voltada para a apropriação libertária e freireana ${ }^{49}$ de mundo.

Destarte, o conteúdo cognitivo e afetivo, que orienta e organiza a atividade na escola, deve chegar ao jovem devidamente planejado e sistematizado, ainda mais porque toda atividade deve ser marcada pela intencionalidade e pelo atendimento às necessidades específicas de um dado contexto (como o mencionado acima). Daí, antes de um professor valer-se da integração entre a atividade filosófica e a atividade pedagógica, há que se considerar quais são os interesses e as volições que devem e podem ser satisfeitos.

Como supracitado de certa maneira, nestas circunstâncias, as vivências afetam a realidade porque são (re)orientadas em sua carga afetiva e cognitiva, posto que são processo e produto do desenvolvimento das funções psicológicas superiores. A integração da apropriação do conhecimento teórico e da afetividade com os interesses e volições contribuem para a formação do pensamento por conceitos e para a reestruturação da maneira como o adolescente enxerga a sua realidade, a si mesmo, a seus coetâneos, o estudo e a função do seu professor. Este pode passar a não ter só o papel de autoridade na orientação de tarefas, mas de parceiro na busca pelo conhecimento ${ }^{50}$.

Esta parceria não é imediata, mas mediada. Para ser construída depende da intencionalidade do conteúdo cognitivo e afetivo, de referências objetivas e subjetivas, para produzir uma relação de confiança recíproca. A escola, por conseguinte, para propiciar a formação do pensamento por conceitos, a apropriação do conhecimento teórico e o desenvolvimento da consciência crítica, não pode ser apenas o núcleo de uma promoção da cultura acumulada sóciohistoricamente mecanizada ou tecnicista, mas deve ter a função primordial de humanizar os indivíduos, valendo-se também das emoções, das vivências.

Quando a afetividade e a volição, os interesses e os desejos, se associam aos traços cognitivos, o pensamento passa a oportunizar meios para o domínio da conduta, a fim de favorecer a aprendizagem, o estudo, para formar e

49 Freire (1993) assevera que apesar de todo processo escolar não ser neutro, que ele não deve ser doutrinário, mas sim libertário, para liberar os sujeitos dos preconceitos e para que possam ser autônomos em suas escolhas e lutas.

50 O que seria filosoficamente interessante, haja vista que se o filósofo é o amigo do conhecimento, nada mais justo do que tornar o estudante amigo do conhecimento também. 
desenvolver uma consciência racional, capaz de sistematizar as contradições, dores, horrores, de modo a analisar criticamente as situações e a procurar soluções criativas para o caos [pessoal, familiar, social...].

Neste ínterim, o professor como parceiro dos processos internos e externos do adolescente, pode aprender a lidar melhor com as crises e exageros, típicos desta fase. Todavia, para isso é preciso ter consciência que na função de ser professor não se mobiliza apenas os mecanismos cognitivos para obter 0 produto da atividade de ensino, até mesmo porque os indivíduos são seres singulares, complexos e integrais.

Ao conhecer melhor o que são as vivências e a necessidade de integrar os aspectos cognitivos, afetivos e volitivos, o professor pode superar o dado pela imediaticidade concreta e aprofundar sua relação com os exageros e crises dos jovens, orientando estes processos para hábitos criativos, fazendo-os experimentar os seus interesses e desejos de conhecimento, mobilizando-os para a apropriação cada vez mais elevada da linguagem, da cultura e dos conceitos por meio dos conteúdos escolares.

As vivências tornam-se, dessarte, o eixo motriz da atividade pedagógica na constituição de uma unidade com a atividade filosófica, podendo contribuir para a formação integral que considera os indivíduos dotados de cognição, afetividade e volição, e que estas não são parte do sujeito, mas seu todo que incorpora necessidades, sentidos e desejos [de objetivação].

A vivência constitui a unidade da personalidade e do entorno tal como aparece no desenvolvimento. Portanto, no desenvolvimento, a unidade dos elementos pessoais e ambientais se realiza em uma série de diversas vivências para a criança. A vivência deve ser entendida como a relação interna da criança como ser humano, com um ou outro momento da realidade. [...] A teoria moderna introduz a vivência como uma unidade de consciência, isto é, como uma unidade na qual as propriedades básicas da consciência aparecem como tais, enquanto na atenção, no pensamento não existe tal relação. A atenção não é uma unidade de consciência, mas um elemento de consciência, desprovido de outros elementos, com a particularidade de que a integridade da consciência, como tal, desaparece. A verdadeira unidade dinâmica da consciência, a unidade plena que constitui a base da consciência, é a experiência.

A vivência tem uma orientação biossocial, é algo intermediário entre a personalidade e o meio, o que significa que a relação da personalidade com o meio revela o que significa um determinado momento dado o meio para a personalidade (VIGOTSKI, 2006, p.383, tradução nossa). 
Conforme Vigotski (2006), a personalidade e a consciência são estruturas compostas por outras estruturas e é por isso que as vivências são consideradas a unidade sistêmica entre ambas e sua formação depende também de relações sistêmicas. Isso ocorre porque é a unidade integral entre ambas que pode consolidar o desenvolvimento dos indivíduos, um desenvolvimento que vise as máximas potencialidades da genericidade humana.

E como predito, não é a orientação e/ou domínio apenas do cognitivo que promove tal movimento; é preciso considerar o humano no homem e sua humanização por completo, ainda mais no espaço da escola. É preciso que o professor organize, amplie e aperfeiçoe a metodologia de ensino no contexto escolar, pois ela não pode considerar apenas a apropriação do teórico, como evidência da promoção do desenvolvimento, mas, também e, sobretudo, que as funções superiores responsáveis pela afetividade, interesse, desejo, motivação, volição impactam na atenção voluntária, por exemplo, que depende delas para a apropriação dos conceitos teóricos.

O objetivo da educação escolar, assim posto, não é saber em que ponto se situa a origem dos interesses, se os indivíduos têm ou não têm interesse pelo estudo, mas saber como mobilizá-lo (VIGOTSKI, 2006). Isso ocorre porque os interesses no processo educativo desempenham o papel de meio, já que é sobre eles que se baseiam toda e qualquer incitação da atividade na aquisição de conhecimentos e na apropriação de sua própria atividade, ou seja, na apropriação e orientação da atividade de comunicação íntima-pessoal e na incorporação da atividade de estudo, no caso dos adolescentes.

Uma das funções do professor, como supracitado, é construir este ambiente que oriente ou crie os interesses para o estudo. Apesar de caótico, contraditório e permeado por crises, o professor que ministra aulas para os indivíduos na fase da adolescência precisa guiá-los para seu desenvolvimento e atividade próxima, pois é esta sua função na atividade de ensino, a partir da perspectiva da Psicologia Histórico-Cultural.

Neste processo as vivências podem formar a unidade e alavancar o desenvolvimento dos interesses, orientando a cognição, a afetividade e a volição, contudo, para conduzi-las adequadamente a este movimento, é preciso mobilizar ações e operações intencionais, como a integração da atividade filosófica e a pedagógica, por exemplo. É possível compreender que esse 
processo se constitua dessa maneira porque, como predito, "os interesses no processo educativo desempenham o papel de meios, já que sobre eles, se baseiam toda incitação à atividade, à aquisição de hábitos e conhecimentos" (VIGOTSKI, 2006, p.38, tradução nossa).

Apropriando-se do conhecimento teórico o adolescente têm maiores chances de desenvolver adequadamente o pensamento por conceitos e passar a dominar os mecanismos que envolvem a formação e a elaboração conceitual, que o conduzirão "mais tarde ou mais cedo a dominar o pensamento dialético" (VIGOTSKI, 2006, p. 68, tradução nossa).

A formação do pensamento, calcado em bases conceituais na adolescência é decisivo, pois ele permite que o jovem adentre em sua realidade interna, no mundo das próprias vivências, porquanto todo o conteúdo do seu pensamento é reestruturado, abrindo para ele o mundo da consciência social objetiva, assim como uma disposição consciente, mais ligada ao concreto. Logo, o adolescente abre espaço para as

questões filosóficas das ciências naturais, da origem do mundo, do ser
humano etc. [...] Ele dedica cada vez mais atenção à política, que
passa a ser muito mais interessante [...] é atraído pela música, para a
arte mais abstrata. [...] Nesta mesma idade, os adolescentes são muito
atraídos pela física, e é também a idade de interesses filosóficos e,
consequentemente, do raciocínio lógico (VIGOTSKI, 2006, p. 64 e 66,
tradução nossa).

Isso mostra que 0 adolescente, quando em uma atividade intencionalmente organizada, para um determinado tipo de desenvolvimento, tem a possibilidade de voltar-se a quaisquer tipos de conhecimentos e apropriarse da cultura elaborada sócio-historicamente, caminhando para em direção à genericidade humana. Destarte, a atividade pedagógica integrada à atividade filosófica na análise do tipo de desenvolvimento que possui o jovem estudante e sua coletividade, pode conduzir o adolescente ou um grupo de adolescentes a voltar suas vivências à atividade de estudo, à filosofia e à formação de uma consciência crítica.

Segundo Vigotski (2006), quando o adolescente participa de um processo em que lhe é possível identificar por si mesmo sua função social e a que classe pertence, ele também passa a participar de forma massiva da atividade social e, portanto, sua plena autodeterminação com uma classe passa a ser também um 
acontecimento decisivo em sua vida. Agora, imagine só o que isso pode impactar em sua vida escolar? Vigotski, citando Blonski, assevera que o "adolescente não é só filho de sua classe social, mas também um membro ativo dela" (VIGOTSKI, 2006, p. 67, tradução nossa). Assim, a Psicologia Histórico-Cultural assume que a educação escolar quando impacta concomitantemente cognição, afetividade e volição, faz do estudante também membro ativo de sua própria vida escolar e de sua classe social. No próximo capítulo, está disposta a intervenção didáticopedagógica realizada no ano de 2017, em que é possível identificar algumas das categorias abordadas até então. 


\section{O MOVIMENTO DE APROPRIAÇÃO DO CONHECIMENTO TEÓRICO- FILOSÓFICO NO ENSINO MÉDIO}

De acordo com a Psicologia Histórico-Cultural, a escola é historicamente construída para promover a escolarização, valendo-se da estrutura geral da sociedade em que está submersa. Isso significa dizer que cada período e cada sociedade organiza a escola para servir seus interesses e para se adequar às suas necessidades (FREIRE, 2016).

De acordo com Duarte (2004b), a sociedade capitalista reivindica dos sistemas de ensino que esses formem os sujeitos, para que estes se ajustem ao que é imprescindível, a fim de movimentar e garantir a manutenção do status quo. Dessarte, a instrução dos sujeitos vai variar e depender da classe social a qual eles pertencem, pois todos devem satisfazer às demandas do capital.

Ademais, a teoria marxiana assevera que a concepção de mundo capitalista pouco aproxima os sujeitos pertencentes ao proletariado de um desenvolvimento que os alce à genericidade humana. Isso se dá porque seu principal instrumento de controle e funcionamento opera a partir da expropriação e da marginalização desses indivíduos que, apesar de constituírem seu corpo central, são excluídos por não poderem ter acesso aos bens que eles mesmos produzem.

A Teoria Histórico-Cultural coloca como uma das principais necessidades o desenvolvimento da atividade de estudo, para mobilizar o movimento de apropriação da cultura elaborada sócio-historicamente na integração do cognitivo, afetivo e volitivo, com a intenção de promover o desenvolvimento dos sujeitos em direção às suas máximas possibilidades no contexto escolar.

A pesquisa de campo que será apresentada e, por consequência, a análise de uma intervenção didático-pedagógica executada no decurso do ano letivo de 2017, no Ensino Médio de uma escola pública estadual de São Paulo, visa mostrar os dados obtidos em sala de aula, que representam o movimento de pesquisa levado a cabo durante as aulas de Filosofia.

Estes dados permitem que se expresse no escopo deste trabalho 0 processo caótico do ensino e as possibilidades de (re)organização de ações e 
operações, tendo em vista a promoção de uma aprendizagem e um ensino desenvolvedor.

Desta feita, o objetivo geral da pesquisa é analisar o processo de superação das contradições do Currículo Escolar do Ensino Médio da Secretaria da Educação do Estado de São Paulo (Seduc-SP) (SÃO PAULO, 2012) a partir da organização de um ensino que possibilite a constituição da unidade afetivocognitivo-volitivo pela mediação do conhecimento teórico-filosófico na atividade pedagógica e filosófica.

Considera-se, a partir das produções no enfoque histórico-cultural, que apesar de a apropriação do conhecimento teórico ter impactado e impactar o desenvolvimento do humano no homem e em sua sociabilidade no decurso de sua história de humanização, a afetividade mobiliza os indivíduos a saltos qualitativos de ordem superior quando integrada à cognição e à volição, porquanto são alterados os sentidos e os interesses dos sujeitos com relação aos objetos e às coisas.

O organizador das ações investigativas, por sua vez, é expresso pela seguinte questão: Quais são as condições necessárias para possibilitar um ensino desenvolvedor, por meio da apropriação do conhecimento teórico no ensino de Filosofia no Ensino Médio de uma escola pública estadual, tendo em vista a integração entre as esferas cognitiva, afetiva e volitiva, feita a partir do que prescreve o Currículo do Estado de São Paulo?

Assim sendo, nesta perspectiva, o ensino que se pretende desenvolvedor deve lançar mão de algumas premissas e organizar ações e operações que dêem acesso a instrumentos, que por sua vez possibilitem aos sujeitos a transformação da realidade concreta e, neste movimento, transformar a si mesmos.

Para movimentar este processo fez-se preciso elaborar um tipo específico de ensino e de aula, que adequasse ações e operações gerais aos pressupostos da Pedagogia Histórico-Crítica e da Psicologia Histórico-Cultural, a fim de propiciar o desenvolvimento para além dos aspectos cognitivos e impactar a afetividade e a volição dos escolares.

Daí o objeto de pesquisa ser a (re)organização do ensino de Filosofia, com a intenção de promover a transformação no psiquismo dos escolares, de um determinado contexto escolar, e possibilitar meios para a superação do caos 
estabelecido pelas políticas públicas, que operam de modo contraditório no cerne da estrutura do ensino paulista.

Ademais, o pressuposto primordial desta tese é que a função da escolarização deve ser fundamentada na premissa de que é preciso mobilizar a apropriação da cultura acumulada sócio-historicamente nos sujeitos submersos em seu contexto, sobretudo da linguagem, signos e símbolos produzidos em milênios, em alguns anos, bem como contribuir para a formação e desenvolvimento das funções psicológicas superiores e, por conseguinte, da consciência e do domínio da conduta por meio da aprendizagem advinda de situações vivenciais ${ }^{51}$.

As situações vivenciais são as abstrações substanciais e, concomitantemente, a unidade de análise da pesquisa, porquanto constituem a unidade entre a atividade pedagógica e a atividade filosófica na representação dialética do movimento de transformação e integração entre o cognitivo, afetivo e volitivo, quando se considera o processo de apropriação do conhecimento teórico-filosófico e as vivências dos estudantes acerca desse processo.

A pesquisa de campo ocorreu no ano de 2017, ano em que esta professora teve atribuídas turmas das $1^{\underline{a}}$ e $3^{\text {a }}$ séries do Ensino Médio no componente curricular Filosofia no período matutino, em uma escola pública estadual pertencente ao município de Cotia-SP, jurisdicionado à Diretoria Regional de Ensino de Carapicuíba.

Por questões metodológicas optou-se por apontar os dados de uma única turma, o início do Ensino Médio, uma $1^{\text {a }}$ série. Ela vem para representar as possibilidades, limites e reveses da realidade concreta caótica e plural, justamente porque pressupõe-se que os escolares não tiveram um contato anterior com a Filosofia, enquanto componente curricular pertencente à grade de ensino.

\footnotetext{
${ }^{51}$ Acerca das situações vivenciais é válido salientar que ela supera qualitativamente o que é proposto pelas aprendizagens vivenciais, conceito discutido nas metodologias ativas. A situação vivencial visa apresentar o movimento de não objetivação e objetivação do processo de integração da atividade pedagógica e filosófica, ou melhor, as crises e os saltos qualitativos para que o escolar se transforme em estudante ao se apropriar e objetivar da gênese dos conceitos imbricados nos conteúdos escolares, o seu modus operandi. Desta feita, o jovem não é conduzido a uma construção do conhecimento cujo ponto de partida e de chegada seja o mesmo, o senso comum, ao contrário disso, parte do produto esperado nas situações vivenciais é a ascensão ao concreto pensado.
} 
É válido salientar que a execução do plano de ensino e de aula ocorreu a partir do primeiro dia letivo de 2017, período em que esta professorapesquisadora ainda não havia ingressado no curso de Doutorado. Assim sendo, a metodologia para análise dos dados é embasada na estrutura de uma pesquisa documental (RICHARDSON, 1999; OLIVEIRA, 1997), que se fundamenta em um criterioso estudo acerca dos registros e documentos produzidos no decurso das aulas ministradas em 2017.

Para compor a análise documental foram utilizados os registros pessoais da professora-pesquisadora, tais como, as produções dos estudantes, fotos, vídeos e gravações de aulas que compuseram o diário vivo de um plano de ensino e de aulas que expressam o transcurso e o processo da trajetória desta pesquisa de campo.

Para além disso, a análise realizada tem como eixo orientador 0 pressuposto de que a atividade filosófica e a atividade pedagógica quando integram o cognitivo, o afetivo e o volitivo podem possibilitar a mobilização do escolar à sua atividade principal e vincular esta à secundária, neste caso, a atividade de estudo (ELKONIN, 1987).

Afinal de contas, o referencial teórico que subsidia este estudo assevera que sem se considerar o afetivo e o volitivo na apropriação do conhecimento teórico, não há como promover um ensino desencadeador de desenvolvimento, sobretudo quando algumas funções psicológicas estão em jogo neste ensino desenvolvedor.

Assim, o capítulo expressa a articulação entre a investigação bibliográfica e conceitual, que se fez necessária nos capítulos anteriores, e a investigação empírica no contexto escolar que será apresentada adiante. Quanto aos procedimentos teórico-metodológicos utilizados, três foram centrais para a sistematização dos dados, a saber, obtenção, organização e análise dos dados. Para cada um, há um princípio que fundamenta e norteia este trabalho, assim como instrumentos que balizam metodologicamente tal apresentação que são, consecutivamente: a intervenção didático-pedagógica, os procedimentos pedagógico-desenvolvimentais, e as abstrações substanciais que culminam na constituição da unidade de análise da pesquisa. A seguir a análise da intervenção didático-pedagógica. 


\subsection{A Caracterização da Pesquisa}

A pesquisa de campo foi orientada para promover em sala de aula um determinado movimento, tendo o conhecimento teórico-filosófico como mediador. Isso significa dizer que é primordial considerar o desenvolvimento do humano no homem, como práxis que orienta a atividade em sala de aula, a fim de alavancar as funções psicológicas superiores necessárias para a constituição de uma consciência crítica.

Esta investigação produzida pela execução de uma intervenção didáticopedagógica de cunho experimental transcorreu durante as aulas do componente curricular Filosofia em unidade escolar pública localizada em uma área central de Cotia, um município pertencente à Região Metropolitana do Estado de São Paulo. As crianças e os jovens regularmente matriculados nesta escola, no período em que foi realizada a pesquisa, pertenciam ao Ensino Fundamental II no período matutino e vespertino, e ao Ensino Médio no período matutino e noturno.

A análise dos dados empíricos realizada neste capítulo visa expressar o processo de objetivação e não objetivação de um plano de ensino executado na escola no ano de 2017. Coloca-se que há o movimento de objetivação e não objetivação, porquanto a realidade concreta seja caótica, contraditória e dialética, em que ora os processos indicam que o ensino se mostra como desenvolvedor, ora em crise (BERNARDES, 2012; FREIRE, 2016).

Tem-se como universo geral da população pesquisada (OLIVEIRA 1997), portanto, 10 turmas com um total de 360 participantes, contando com as eventualidades geradas pelos movimentos de evasão, remanejamento entre turmas e transferências entre unidades escolares. Destas 10 turmas, 8 turmas eram de $1^{\text {a }}$ série e 2 turmas de $3^{\underline{a}}$ série, todas estas alocadas no período matutino de uma escola pública estadual no município de Cotia-SP, como predito.

Para representar este todo caótico e o movimento da pesquisa, a análise e o estudo foram realizados, elencando uma única turma. Esta turma foi escolhida por expressar o movimento de objetivação e não objetivação do 
processo de escolarização, haja vista que a atividade pedagógica e a atividade filosófica não se expressam por um movimento linear (BERNARDES, 2012; FREIRE, 2016).

Assim sendo, a turma da 1 a série do Ensino Médio selecionada possuía 36 escolares com idade entre 14 e 17 anos, de diferentes níveis sociais, que residiam em pontos diversos do município e inclusive em outras cidades.

A pesquisa documental consistiu na análise do registro das aulas, realizada a partir de um caderno pessoal da professora-pesquisadora, em que consta uma descrição sintética dos arranjos da sala de aula, assim como do exame minucioso de gravações em áudio e vídeo, de fotos das situações categorizadas e vivenciadas, que são de ordem coletiva e individual - dentre as quais, algumas serão devidamente apresentadas - e da produção dos escolares/estudantes, colhida a partir das tarefas solicitadas como, por exemplo, de esquemas, trabalhos, redações, sínteses textuais, respostas dissertativas, seminários, desenhos, vídeos e afins.

É válido salientar que o caderno pessoal da professora-pesquisadora é o registro de um pensamento acerca da situação vivencial em processo, mas que este não é objeto direto de análise, é apoio, fonte de parte dos dados. Estes emergem a partir de cada procedimento pedagógico, que irá apontar os indicadores de como se deu o processo de desenvolvimento dos escolares em estudantes, ou mesmo evidenciar as crises, os momentos em que não ocorreram avanços, o porquê estiveram ou não em atividade ${ }^{52}$ (FREIRE, 2016).

Esta turma teve em seu plano de ensino e de aulas, a adaptação do Currículo da Seduc-SP (SÃO PAULO, 2012) [válido naquele período] e a (re)adequação de ações, operações e procedimentos, com a finalidade de promover e acompanhar o processo de aprendizagem não apenas quantitativamente, mas, sobretudo, qualitativamente, por isso, diz-se que é intervenção didático-pedagógica.

Assim sendo, foram considerados para a elaboração do plano de ensino e de aula, na reestruturação do conteúdo do Currículo da Seduc-SP (SÃO PAULO, 2012), três pontos fundamentais que balizam a Teoria Histórico-

52 Como indicado, o processo de desenvolvimento não é linear, tampouco contínuo, mas, contraditório e caótico, o que não significa que ele não esteja ocorrendo. 
Cultural, a saber, a) o caráter social para a formação e/ou desenvolvimento das funções psicológicas superiores na constituição de uma coletividade de estudo, em que se pese a periodização do desenvolvimento humano; b) a necessidade de superação das contradições e das imposições sócio-políticas alienantes e alienadoras presentes no decurso da história dos processos de escolarização; c) a defesa de que o desenvolvimento do pensamento teórico e da consciência, como produto da atividade prática humana, que deve ser sistematizada e integrada às esferas afetiva e volitiva, favorece a transformação das funções psicológicas superiores na mediação de signos, símbolos e instrumentos.

\subsection{A Sistematização de um Plano de Ensino que visa se alçar à Atividade Pedagógica}

Considerando a intencionalidade da execução da pesquisa de campo, que se deu através de uma intervenção didático-pedagógica de cunho experimental, a partir de um referencial teórico específico, a Teoria Histórico-Cultural, a Psicologia Histórico-Cultural e a Pedagogia Histórico-Crítica, observou-se que era preciso (re)adequar a organização do Currículo da Secretaria da Educação do Estado de São Paulo - Seduc-SP (SÃO PAULO, 2012) no que concerne aos conteúdos.

Isso porque o ensino, segundo os pressupostos dos referenciais teóricos mencionados acima, deve estar organizado e pronto para atender às necessidades e às especificidades do contexto, no qual pretende alavancar 0 desenvolvimento e a aprendizagem. Assim, se a intervenção ocorreu a partir de um Currículo único, que possuía [e ainda possui em sua versão reformulada] uma única metodologia de conteúdo e sequência didática no que diz respeito aos procedimentos e práticas de ensino e aprendizagem que homogeneizaram este processo, foi preciso (re)organizar os conteúdos e buscar uma metodologia que melhor atendesse àquele contexto.

Mas, reorganizar em que sentido? No sentido de que foi escolhida uma

determinada metodologia que abarcasse a atividade de ensino, de estudo e a filosófica de tal forma que perpassasse do simples ou da realidade histórica, 
objetiva e caótica, para o mais complexo. A intenção era de que o conhecimento fosse o mediador da formação, desenvolvimento e transformação do pensamento, para que ele se alçasse ao universo das abstrações, que se situam na passagem do concreto ao concreto pensado, com a finalidade de propor ao escolar/estudante adentrar em atividade filosófica, por meio do movimento de conhecer o que é o conhecimento teórico-filosófico, saindo do senso comum e ascendendo à consciência crítica.

A estrutura do Currículo da Seduc-SP (SÃO PAULO, 2012), por sua vez, se diz fundamentada por uma episteme oriunda de uma teoria de pensamento crítico, cuja tendência é progressista e pautada em uma reflexão Histórico-Crítica e Crítico-Social dos conteúdos. Contudo, em linhas gerais, observa-se que sua organização geral se dá basicamente a partir de uma orientação construtivista, traçada pela pedagogia do aprender a aprender e pela Pedagogia dos Projetos, para além de articular diferentes tendências, mas sempre se voltando para os princípios de construção de competências e habilidades [há muito superadas pela Psicologia Histórico-Cultural] (DUARTE, 2004a; LIBÂNEO,1999; MIZUKAMI, 1986).

Sforni e Galuch (2006), ao analisarem a unidade entre o conteúdo escolar e o desenvolvimento em Currículos e Metodologias pautadas no construtivismo e no escolanovismo, asseveram que é difícil ao estudante na escola conseguir emitir opiniões que ultrapassem o conhecimento empírico, imediato, pois os conceitos espontâneos que adquiriu nas situações da sua vida cotidiana são basicamente tomados como ponto de partida e de chegada, nos sistemas de ensino em que essas teorias são seu principal subsídio.

A construção de habilidades e competências tal como se apresenta no Currículo (SÃO PAULO, 2012) não se distancia disso, pois os escolares têm os conteúdos mediados por um saber espontâneo, vinculado ao imediato, ao senso comum, que se aproxima vez ou outra de formas mais elaboradas do pensamento crítico, no entanto, não chegam a objetivá-lo, como assinala Freire (2016).

Desta forma, o procedimento teórico-metodológico utilizado para a sistematização dos dados no que concerne a sua obtenção, ao fim e ao cabo, visa explicitar, em meio à intervenção didático-pedagógica, e evidenciar o produto da relação da professora-pesquisadora e da pesquisadora-professora 
com os fatos comuns na construção dos fatos científicos. Segundo Vigotski (2004a, p. 234), "o fato real e o fato científico distinguem-se precisamente um do outro pelo fato de que este último constitui o fato real reconhecido em determinado sistema, isto é, uma abstração de certos traços da inesgotável soma de signos do fato natural".

O procedimento metodológico, para a organização do plano de ensino e de aulas que orienta a atividade filosófica e a atividade pedagógica na presente pesquisa, baseia-se no método genético-experimental de Vigotski (2000b), que considera a natureza dinâmica dos processos psicológicos superiores e procura apresentar essa dimensão dinâmica do fenômeno, por meio da reconstrução dos ciclos de formação e de desenvolvimento das funções psicológicas superiores.

Já o procedimento metodológico, adotado para a análise dos dados, por sua vez, só é possível se o pesquisador engendrar na realidade objetiva um determinado movimento em que intencionalmente sejam propiciadas ações que formem e desenvolvam no próprio processo de formação e transformação os objetos de estudo (VIGOTSKI, 2006).

Assim, para que a intervenção didático-pedagógica fosse objetivada, foi necessário organizar um plano de ensino e de aulas em que a sequência do conhecimento teórico-filosófico favorecesse a atividade dos escolares/estudantes. É importante notar que não é só a especificidade da aula, seja pelo tipo de organização da atividade de ensino, seja pela forma como o conceito foi colocado como mediador ou pela singularidade dos sujeitos executores da atividade, que foi propiciadora para que se promovesse a integração esperada.

A unidade provocada pelas interações sociais ocorridas, no cerne da atividade filosófica e da atividade pedagógica (FREIRE, 2016), é um dos principais indicadores que sinalizam algumas possibilidades que desencadearam o estudo, a aprendizagem e o desenvolvimento nesse processo de escolarização, bem como apresenta os indícios de alteração na forma como os estudantes se apropriam, desenvolvem e dominam sua conduta.

No entanto, é mister estabelecer que a atividade pedagógica necessita de certas ações e operações para desencadear a unidade entre a atividade de ensino do professor e a atividade de estudo do estudante (BERNARDES, 2012), sobretudo, porque o escolar não se torna estudante sem ser mobilizado para a 
atividade de estudo, o que significa dizer que é preciso criar situações em que o escolar compreenda o sentido e o significado do estudar para sentir a necessidade de estudar.

Cabe à escola, de acordo com a Psicologia Histórico-Cultural e a Pedagogia Histórico-Crítica, trabalhar com o conhecimento teórico de forma que o escolar/estudante se aproprie de formas de pensar, analisar, reelaborar e agir conscientes, a fim de ultrapassar o conhecimento empírico.

Portanto, a partir do estudo do Currículo (SÃO PAULO, 2012), procurouse elaborar um o plano de ensino e de aula que contemplasse as possibilidades de seus conteúdos, sequências e avaliações para gerar uma aprendizagem que impactasse os escolares para além da cognição, que aqui se expressa por um ensino voltado para a objetivação da atividade pedagógica e da atividade filosófica, tendo os interesses, a cognição, a afetividade e a volição como eixos motrizes para a apropriação do conhecimento teórico-filosófico.

$\mathrm{Na}$ análise dos dados, serão apresentadas as situações vivenciais, cujo objetivo é mostrar como certos procedimentos podem mobilizar um movimento para a atividade, o estudo, a aprendizagem e o desenvolvimento. As situações vivenciais identificam e explicitam as manifestações externas e internas do efeito da formação e desenvolvimento das funções psicológicas superiores engendradas a partir da integração da atividade pedagógica com a atividade filosófica que, por sua vez, integram cognitivo, afetivo, volitivo e as vivências.

A seguir, apresenta-se o movimento para a elaboração do plano de ensino e de aula que se constituiu basilar para a objetivação da intervenção didáticopedagógica e dos procedimentos pedagógico-desenvolvimentais. Entende-se que esse passo é fundamental, uma vez que objetiva-se transcender o caráter caótico, pragmático e tecnicista que é possível inferir na maneira como estão organizados no Currículo da Seduc-SP a ordem dos conceitos e as atividades ad hoc, que sustentariam a sua apropriação. 


\subsubsection{A Elaboração do Plano de Ensino}

A pesquisa de campo se passa no ano de 2017, ano em que, apesar das paulatinas alterações nas políticas públicas, a determinação dada pela SeducSP era seguir a sequência didática oportunizada pelo Currículo (SÃO PAULO, 2012) ainda em curso e seu principal articulador, a Matriz de Avaliação Processual (SÃO PAULO, 2016). Atualmente, como supracitado, há um movimento de transição do sistema de ensino paulista, por ocasião da Lei 13.415, de 16 de fevereiro 2017 (BRASIL, 2017), que trata da Reforma do Ensino Médio, voltado para contemplar a estrutura da BNCC (Base Nacional Comum Curricular), por isso a reformulação das bases curriculares pautadas no Programa Inova 53 .

No entanto, julga-se que o princípio geral que vislumbra a necessidade de (re)organizar o conteúdo do Currículo da Seduc-SP, que vigorava no ano de 2017, pode se adequar a qualquer material, porquanto sua estrutura básica é promover e adequar a passagem do senso comum, para a apropriação do conhecimento teórico-filosófico e, para além disso, atender às necessidades e especificidades dos escolares/estudantes considerando a realidade concreta do contexto escolar em que se encontram.

Assim sendo, a partir do estudo e análise do Currículo da Seduc-SP (SÃO PAULO, 2012) e considerando a base geral da política pública de ofertar um conteúdo mínimo e comum aos escolares, os conceitos foram (re)organizados com o propósito de propiciar a objetivação do princípio mencionado acima. Isso significa que o plano de ensino contemplou os conteúdos que eram previstos em lei, ordenando-os em conformidade com a máxima da unidade dada na atividade filosófica (FREIRE, 2016).

Segundo Freire (2016), a atividade filosófica é a manifestação da unidade molar da atividade prática humana que passa do concreto-real ao abstrato e do

53 As informações preliminares acerca do Programa Inova constam nos sites http://inovaeducacao.escoladeformacao.sp.gov.br/ http://www.saopaulo.sp.gov.br/spnoticias/governo-de-sp-lanca-o-inova-educacao/, último acesso em 16/06/2019). Sobre o Novo Ensino Médio em São Paulo, cujos Itinerários Formativos foram oficialmente lançados em 06 de agosto de 2021, é possível ver mais em https://novoensinomedio.educacao.sp.gov.br/. 
abstrato para o concreto-pensado. A intenção, portanto, é valer-se do ensino da Filosofia para promover o desenvolvimento do pensamento teórico na vida objetiva dos escolares, por meio da passagem de um tipo de conhecimento acerca da realidade empírica a outro de nível qualitativamente superior, o modus operandi filosófico que será explicitado adiante.

A partir deste pressuposto o modo de ação no ensino da Filosofia é a mediação do conhecimento teórico-filosófico, como instrumento que pode (re)qualificar a relação do escolar para com a escola e com os estudos. A intencionalidade desse tipo de ensino é provocar o desenvolvimento por meio da atividade filosófica objetivada na vida concreta do escolar, transformando-o em estudante.

Tem-se por hipótese, por conseguinte, que a apropriação do conhecimento-teórico pode transformar o escolar, aquele que está nos processos de escolarização e participa sem muitas vezes estar plenamente incluído na escola e, sobretudo, nos processos de ensino e de aprendizagem, em aquele que estuda e está em atividade por meio do desenvolvimento do pensamento por conceitos e por meio da integração entre interesses, cognição, afetividade e volição. Daí no decurso do texto o termo escolar/estudante indicará quando a percepção da professora, a partir da análise dos dados, observa que estes indivíduos estão em movimento de transição, todavia, este processo não ocorre espontaneamente.

É importante sinalizar que a (re)organização primeira foi pautada pela sistematização dos conteúdos, de tal forma que os conceitos fossem trabalhados em conformidade com a sua historicidade, considerando uma linha temporal que propiciasse a apresentação do desenvolvimento da Filosofia, enquanto conhecimento teórico que é produto e produtor do humano no homem. Isso foi pensado, sobretudo, porque se tratava de uma turma da $1^{\text {a }}$ série do Ensino Médio que, a priori, nunca tinha tido contato com o componente curricular.

Por conseguinte, os modos gerais, para a sistematização, elaboração e execução do plano de ensino e de aulas, partem da compreensão de que há de se considerar o caráter caótico, dialético e contraditório dos sistemas de ensino e das relações que permeiam o ambiente escolar, sobretudo, a função social do professor que, nos termos da Teoria Histórico-Cultural, tem por necessidade 
mobilizar o escolar à atividade de estudo para a apreensão crítica do significado da escola e do estudar (BERNARDES, 2012; FREIRE, 2016).

Assim, tem-se por princípios organizadores do plano de ensino e de aula 1. a atividade como essência da práxis humana transformadora (VÁZQUEZ, 1977; BERNARDES, 2012) que conscientemente orientada, com a intenção de integrar teoria e prática na transformação não apenas das dimensões objetivas, mas também subjetivas da atividade, refere-se à atividade produtiva e políticosocial humana devidamente sistematizada, para que os sujeitos possam se apropriar das objetivações resultantes da atividade das gerações passadas (LEONTIEV, 2004); 2. o ensino desenvolvedor (DAVIDOV, 1988), em que a organização intencional de ações e operações gerais, para a manifestação da atividade pedagógica e da atividade filosófica, na intervenção didáticopedagógica, tenha a finalidade específica de propiciar a formação e 0 desenvolvimento das funções psicológicas superiores nos escolares, transformando-os em estudantes; 3 . a integração dos interesses e das vivências com o cognitivo-afetivo-volitivo, como eixo motriz para a apropriação dos nexos internos do conhecimento teórico, a fim de promover saltos qualitativos no desenvolvimento psicológico superior dos estudantes, com a transformação da qualidade observável no tipo de seus pensamentos, a saber, transformar algumas funções psicológicas de elementares em superiores (VIGOTSKI, 2000b, 2006).

Outra importante sinalização para a elaboração do plano de ensino é, que o contexto escolar, a partir dos referenciais supracitados, tem que considerar a Zona de Desenvolvimento Proximal (VIGOTSKI, 2000a, 2007), a fim de alavancar a aprendizagem e os processos de desenvolvimento das funções psicológicas superiores, bem como propiciar a reflexão acerca do movimento de segregação e da homogeneidade incutidos na escola, porquanto os sistemas de ensino, ao servir o modus operandi da sociedade capitalista, "afasta os sujeitos da apropriação dos bens culturais ao considerar que os escolares possuem certo padrão nos processos de aprendizagem e/ou apropriação dos conteúdos ao ter um único Currículo como plano de ensino" (FREIRE, 2016, p. 110, grifo da autora), sobretudo, quando obriga o professor a segui-lo rigorosamente.

Esta organização do plano de ensino e de aulas tem em vista a relação singular-particular-universal (OLIVEIRA, 2005), em que o professor concorre, 
para ser sujeito da própria ação. Nisso, a particularidade é o contexto escolar, que representa a realidade objetiva possível de ser generalizada, nas escolas estaduais do Estado de São Paulo que atuam com o Ensino Médio.

O conhecimento teórico-filosófico, por sua vez, aqui, perfaz a mediação para a constituição de um ensino desenvolvedor, a partir das possibilidades concretas dos sujeitos da instituição escolar, que representam a singularidade nesta relação; mediação esta, cuja intenção é mobilizar a atividade, tanto na profissão da professora-pesquisadora, quanto na vida objetiva dos escolares, a fim de objetivar a universalidade que está na Zona de Desenvolvimento Próximo dos indivíduos e nas possibilidades dadas, na integração entre a cogniçãoafetividade-volição.

Este plano de ensino buscou propiciar a passagem do desenvolvimento real ${ }^{54}$ para o próximo desenvolvimento (VIGOTISKI, 2000a, 2007), a partir do que é ofertado para uma dada realidade escolar. É válido apontar que a estrutura original também propicia um tipo de desenvolvimento, mas este tem inculcado em si a expropriação do sujeito de sua genericidade (FREIRE, 2016).

Isso se dá, porque a intenção dos sistemas de ensino de forma geral está pautada na formação mercadológica, em que as pedagogias do aprender a aprender e dos projetos (MARTINS; DUARTE, 2010) inculcam a necessidade de uma escolarização integral dos jovens, a fim de servir à sociedade no que melhor Ihes compete: a constituição de uma mão-de-obra alienada e cada vez mais subserviente ao seu propósito inerente de manter as engrenagens do sistema em funcionamento.

Ao sopesar uma prática didática que visa o desenvolvimento próximo e que propicie a transformação da consciência dos sujeitos submersos em seu contexto, a relação articulada entre as esferas cognitiva, afetiva e volitiva não pode se dar de maneira linear. Isso ocorre porque as relações de aprendizagem e desenvolvimento não são lineares, mas são como duas linhas que ora correm paralelamente, ora se cruzam (VIGOTSKI, 2000a), num movimento dinâmico e

\footnotetext{
${ }^{54}$ De acordo com Vigotski, "[...] a distância entre o nível de desenvolvimento real, que se costuma determinar através da solução independente de problemas, e o nível de desenvolvimento potencial, determinado através da solução de um problema sob a orientação de um adulto ou em colaboração com companheiros mais capazes [...]" é a Zona de Desenvolvimento Proximal (VIGOTSKI, 2007, p. 97).
} 
dialético, permeado por crises e saltos qualitativos, na promoção das máximas transformações na constituição psíquica dos sujeitos, como predito.

É preciso explicitar de antemão, que existe uma intencionalidade nas escolhas feitas por esta professora com relação aos conteúdos e à didática adotada, ela advém de necessidades e motivos oriundos de uma análise pormenorizada das contradições de um dado sistema de ensino. A maneira como o conteúdo e a didática foram elencadas e sistematizadas compõem as intervenções didático-pedagógicas, mas, para além disso, visam contemplar a consciência de função e de classe desta professora, que acolheu como batalha superar o caos de um Currículo que em vez de alavancar o desenvolvimento em direção às máximas possibilidades da genericidade humana, condena os escolares/estudantes a um ensino homogeneizado, pobre e ultrajante, e a uma prática pedagógica do professor alienante e alienadora ["chocha, capenga, manca, anêmica, frágil e inconsistente'].

Destarte, tem-se por plano de ensino o realinhamento de ações e operações impostas pelo Currículo (SÃO PAULO, 2012), que demandaram a readequação dos conteúdos. Esta reorganização para o plano de ensino e de aulas está presente no apêndice desta pesquisa. A seguir, apresenta-se a ementa do componente curricular que serviu como base para o plano de ensino e de aula executado na intervenção didático-pedagógica.

Disciplina: Filosofia

Carga horária teórica: 44 semanas

Professora: Sandra Braga Freire

Ano letivo: 2017

\section{Ementa}

O componente curricular se propõe promover a apropriação de conceitos teóricos elaborados pela Filosofia, bem como da cultura humana produzida sócio-historicamente. Desta feita, está voltado para o desenvolvimento e formação do pensamento por conceitos, abstrato e dialético, na vida objetiva dos escolares/estudantes, a partir da articulação entre as esferas cognitiva-afetivavolitiva para mobilizar os sujeitos à atividade filosófica, reflexiva e crítica para com a realidade concreta. 


\section{Objetivos}

Geral

- Compreender a Filosofia como construção simbólica e, portanto, como parte da necessidade humana que produz a cultura elaborada sócio-historicamente e que, quando apropriada pelos estudantes, pode conduzi-los a compreender a realidade concreta de forma crítica, transformando sua consciência e emancipando-os dos estereótipos formados de modo contumaz, pelo sistema de ensino paulista.

Específicos (Didáticos)

- Superar o conhecimento propiciado pelo senso comum;

- Conhecer e se apropriar dos conceitos da Filosofia, abarcados pelos conteúdos escolares;

- Perceber, a partir de sua apropriação, os conhecimentos teóricos elaborados pela Filosofia no decorrer da história como mutáveis, dependendo do contexto em que viviam os sujeitos que criaram as teorias estudadas;

- Ler filosoficamente textos não-filosóficos e identificar a presença da Filosofia na realidade concreta;

- Expressar por escrito e oralmente conceitos da Filosofia;

- Construir argumentos filosóficos e discutir de maneira autônoma a Filosofia;

- Apropriar-se da atividade filosófica para avaliar e analisar criticamente a realidade concreta;

\section{Específicos (Intervenção Didático-Pedagógica)}

- Promover o desenvolvimento da atividade de comunicação íntima-pessoal e da atividade de estudo integrada às demais atividades do período da adolescência no contexto escolar.

- Analisar a realidade escolar, observando como ocorrem as relações inter e intrapessoais para a formação e o desenvolvimento das formas superiores de comportamento, por meio da mediação do conhecimento teórico-filosófico em sala de aula, na integração do afetivo, do cognitivo, das volições e das vivências. 


\section{Procedimentos didáticos}

Técnicas

- Aulas expositivo-dialogadas;

- Leitura coletiva de textos, debates e seminários;

- Leitura de textos de gêneros variados, a partir da perspectiva filosófica;

- Estudos em sala de aula;

- Delimitação prévia de grupos de trabalho (definidos de acordo com a quantidade de escolares/estudantes da turma) para auxiliar no andamento das aulas, de acordo com os temas propostos;

- Elaboração de sínteses da aula;

- Tutoria (orientação) presencial e on-line, para a organização dos estudos (utilizando o WhatsApp como instrumento para tutoria remota);

- Formações para a produção autoral de textos filosóficos;

- Estudo acerca de intervenções artísticas que utilizam a Filosofia como meio de expressão;

- Orientação quanto à pesquisa de campo, a fim de procurar a presença da Filosofia na realidade concreta.

Recursos

- Quadro-negro (lousa), computador e projetor multimídia para projeção de arquivos e vídeos, se necessário;

- Textos e outros recursos bibliográficos;

- Uso pedagógico das redes sociais (WhatsApp e Facebook).

\section{Avaliações}

\section{Diagnóstica}

Diagnosticar as dificuldades e potencialidades individuais e coletivas, a fim de intervir adequadamente no processo de escolarização.

\section{Formativa}

O processo de avaliação será contínuo, priorizando o aspecto formativo e qualitativo das tarefas escolares sobre o quantitativo. A finalidade é avaliar para ensinar e aprender, formar e favorecer o desenvolvimento. 
Será considerado o envolvimento nos debates e na exposição de ideias, além da apresentação de resumos, sínteses e outras formas de registro das reflexões críticas.

Poderá haver uma prova (avaliação dissertativa e/ou objetiva), que levará em conta a interpretação dos textos estudados, a clareza na exposição das ideias, a correção linguística e a apropriação dos conceitos, no entanto, como predito, os aspectos qualitativos (o processo de desenvolvimento) prevalecerão sobre os quantitativos.

Trabalho-síntese dos textos trabalhados e das discussões realizadas

A nota final será obtida por meio da participação ativa em todas as avaliações (desde a participação em aulas mediante exposições, debates e perguntas, até as avaliações formais, tais como, prova e trabalhos-síntese e seminários).

O produto almejado é que os escolares, como estudantes, produzam maneiras de filosofar nas categorias: defesa do conhecimento teórico, tendo como exemplos de exposição, a objetivação dos procedimentos didático-pedagógicos dados, por meio do esquema conceitual (com estrutura formal ou informal, desde que adequada e devidamente sistematizada pelos estudantes), seminários cujo produto cultural seja composto por apresentações autorais, tanto teoricamente, quanto no que concerne à elaboração de vídeos de cunho filosófico, intervenções artísticas na sala de aula e/ou na/para a escola, saraus, peças de teatro, músicas e afins.

O café filosófico representa a síntese bimestral das tarefas feitas e conceitos apropriados no contexto escolar. Uma autoavaliação tanto do processo de ensino, quanto do processo de aprendizagem.

É válido salientar que a atividade de estudo e a apropriação dos conceitos mediadores constituem parte da atividade dos estudantes e que, a curto, médio ou longo prazo, espera-se que esse processo possa impactar e/ou impulsionar os estudantes a produzir conhecimento e cultura para a emancipação de suas consciências, mobilizando e propiciando autonomia de interesses, para sua cognição, afetividade e volição.

\section{Cronograma de atividades}


Planejar a ordem dos conteúdos é de suma importância, principalmente porque a prática desse plano de ensino e de aulas dar-se-á com a $1^{\text {a }}$ série do Ensino Médio do período matutino que, se pressupõe não ter mantido contato escolar anteriormente com a Filosofia, e conta com aulas previstas duas vezes por semana, com duração de 50 minutos cada.

\section{Tema central}

Conhecer qual é a necessidade de produção do conhecimento pelo ser humano, para elaboração de cultura, por meio da história da Filosofia, enquanto meio integrador do desenvolvimento da humanidade no ser humano.

Após a apresentação da ementa ofertada aos alunos, passar-se-á, a seguir, à discussão de como se deu a intervenção didático-pedagógica promovida por esta professora-pesquisadora, articulando a atividade filosófica à pedagógica, nas situações vivenciais de ensino planejadas para o ano letivo de 2017, nesta turma de $1^{a}$ série do Ensino Médio.

\subsection{A Atividade Filosófica e a Atividade Pedagógica nas Situações Vivenciais de Ensino: Uma Intervenção Didático-Pedagógica em meio ao Caos do Ensino Paulista}

A função da escolarização fundamentada nas premissas da Teoria Histórico-Cultural, da Psicologia Histórico-Cultural e da Pedagogia HistóricoCrítica é mobilizar a apropriação da cultura acumulada sócio-historicamente, sobretudo da linguagem, que fora produzida em milênios, no tempo dado pelos processos de mediação do conhecimento teórico na escola. Outra função, a partir disso, é contribuir para a formação e desenvolvimento das funções psicológicas superiores e da consciência por meio da aprendizagem advinda das experiências escolares, na superação das contradições impostas, por um sistema alienador da educação escolar.

A educação escolar, nestes termos, é voltada para a socialização de um conhecimento que visa mediar a gênese dos conceitos, ir à raiz destes para 
empreender processos que mexam com os nexos-causais onto e filogeneticamente e tem em-si e para-si55 a intenção de sair de uma compreensão limitada dos fenômenos, buscando observá-los de forma pormenorizada.

Antes de ir à gênese dos conceitos é preciso compreender a realidade para além da aparência e entender que a curiosidade é um traço típico do homem que busca caminhar em direção à genericidade humana, para deslindar a pseudoconcreticidade, porém essa curiosidade também não é imediata. Neste sentido, a Filosofia se coloca nesta pesquisa, como mediadora de sentidos e significados, interesses, volições e conceitos teóricos, com a intenção de realizar um movimento das coisas que vai para além da aparência, propiciando a possibilidade de uma análise crítica e para si de um determinado contexto.

Conforme Freire (2016), a apropriação dos nexos internos dos conceitos teóricos elaborados sócio-historicamente na atividade pedagógica pode favorecer um processo de formação privilegiado na aprendizagem do conhecimento teórico em sua máxima elaboração. No contexto escolar a passagem do em si ao para si pode ser possibilitada pelas mediações simbólicas e pela forma como se dão as relações interfuncionais de outras funções psicológicas superiores na integração do cognitivo, afetivo e volitivo.

Coloca-se que tal ensino é para si, porque promove a transformação das estruturas psíquicas dos sujeitos por meio da apropriação dos bens culturais, na compreensão do modus faciendi humano, forjado na elaboração do conhecimento teórico, o qual pode colaborar com o desenvolvimento das funções psíquicas superiores dos escolares, na medida em que eles também se transformam em estudantes.

O combustível que move este corpo de necessidades advém da curiosidade, da admiração, do caos e da contradição. A mediação do conhecimento teórico-filosófico reside na orientação que se exerce de tal maneira a conduzir o indivíduo de uma percepção imbuída de senso comum,

55 Marx e Engels (2005) se apropriam do em si e do para si hegeliano. Vigotski (2004b), Kosik (1969) e Heller (1987), por sua vez, abstraem da teoria marxiana que, quando o sujeito possui uma consciência em si esta ainda é elementar, alienada e impossibilitada de fazer escolhas sem outrem, enquanto a consciência para si, por ser específica de um processo superior, traz ao sujeito a possibilidade de um desenvolvimento voltado à genericidade humana. 
estereótipos e preconceitos, para uma que seja mais arrazoada, crítica e atenta, por isso, como predito, diz-se que o conhecimento mediado em sala de aula nesta pesquisa é específico e tem um olhar que vai ao cerne das questões, hipóteses, situações, objetos, contextos e afins. É a estrutura da mediação do particular, do singular, rumo ao universal.

Contudo, este movimento não ocorre de forma espontânea. Fazem-se necessárias múltiplas transformações qualitativas na superação da realidade objetiva, porquanto aqui entende-se que seja o sistema de ensino, que se faz historicamente contraditório, tornando-se muitas vezes impeditivo de determinadas relações. Inclusive, às vezes, é o próprio profissional da educação escolar que deve, por si, romper o véu de Ate ${ }^{56}$, para vislumbrar o apocalipse que se aproxima e decidir, por encarar ou não, conscientemente ou não, o caos posto pela estrutura educativa em andamento.

Para empreender o movimento da intervenção didático-pedagógica em sala de aula, alguns procedimentos foram necessários, como mostrar ao escolar de forma clara e distinta o contrato pedagógico e quais eram as normas e regras para a aula. Este contrato não consistia em cristalizar ações, mas informar inicialmente aos jovens quais são as regras do jogo de que ele iria participar, apontando que estas não eram fixas e que poderiam contar com a colaboração deles para alterações que melhorassem as relações de ensino e de aprendizagem. Nestes termos, o apontamento de normas e regras de um contrato pedagógico não é ato impositivo, mas educativo, para transformar o comportamento e a relação dos escolares com a escola e com os estudos, afinal de contas, o domínio de conduta não é obtido na execução mecânica de algo, mas na compreensão do porquê das coisas (GRAMSCI, 2000a, 2020; VIGOTSKI, 2006).

É importante notar que uma das primeiras formas de mobilização para a atividade nos estudantes, perpassa pelo movimento em que eles se sintam pertencentes e atuantes na constituição dos processos de escolarização. Até mesmo porque a atividade de estudo não reside apenas no estudar, mas,

${ }^{56}$ A deusa que personifica o Erro. Era uma divindade leve e ágil e seus pés pousavam nas cabeças dos mortais sem que eles se apercebessem, induzindo-os a cometer falhas de julgamento. Foi precipitada do Olimpo por Zeus e nunca mais pode retornar para a convivência dos deuses, permanecendo exilada entre os mortais (GRIMAL, 2000, p. 52-53). 
sobretudo, em participar da construção de certas ações e operações que contribuam para a adequada constituição da atividade na escola como, por exemplo, a reelaboração do contrato pedagógico.

O eixo orientador para a análise da integração da atividade pedagógica com a atividade filosófica, por sua vez, é examinar como estas atividades podem possibilitar, através de seus instrumentos, metodologias, ações e operações, a apropriação do conhecimento teórico-filosófico e a integração entre o cognitivo, afetivo e o volitivo.

A tese defendida na intervenção didático-pedagógica, por sua vez, é a de que a atividade filosófica (FREIRE, 2016) e a atividade pedagógica (BERNARDES, 2009) têm a possibilidade de mobilizar a integração entre o afetivo, cognitivo e o volitivo e alavancar o desenvolvimento das funções psicológicas superiores, quando se tem o conhecimento teórico como mediador das relações escolares, em um processo que é dialético, que considera as contradições e caos tanto do sistema, quanto do período de vida dos jovens estudantes e suas vivências.

As atividades integradas constituem, assim, importante instrumento que podem possibilitar, para além da integração do ensino e do estudo, como meios desenvolvedores das funções psicológicas superiores dos sujeitos submersos nas relações escolares, a promoção da apropriação dos conhecimentos teóricosfilosóficos no desenvolvimento da consciência crítica, pode impactar a afetividade, a volição, os interesses e as vivências, direcionando-as para a transformação da cognição em direção à genericidade humana sensível a perceber as nuances, as disparidades e as contradições da realidade concreta e (re)qualificar a forma como os escolares/estudantes veem e incorporam os conceitos e categorias mediadoras das relações, não apenas na escola, mas, sobretudo para além de seus muros.

Nisso, as tarefas realizadas em sala de aula e/ou os trabalhos e provas entregues servem como uma espécie de termômetro e guia do andamento da atividade em contexto escolar. Isso porque a análise destas tarefas pôde proporcionar ao professor conhecer o que o jovem conhecia ou não, quais eram os entraves e reveses que eles estavam enfrentando, para estabelecer como e quais formas poderiam assumir as ações, a fim de que o conhecimento teórico se tornasse o mediador das relações escolares, bem como para saber por quais 
meios o jovem poderia ser conduzido para a sua Zona de Desenvolvimento Proximal.

Deste modo, a intervenção didático-pedagógica foi analisada por meio da seleção de situações vivenciais, denominadas assim porque são recortes de momentos que representam o movimento da atividade em sala de aula; é o delineamento sobre o momento de certas vivências que expressam os indícios do processo dialético de objetivação e não objetivação do desenvolvimento das funções psicológicas superiores e a integração do cognitivo-afetivo-volitivo no contexto escolar.

Deste modo, é importante evidenciar, mais uma vez, que as condições reais são, de certo modo, o piparote inicial para a (re)organização dos conteúdos e para a sistematização das intervenções didático-pedagógicas, haja vista que de algum modo é a realidade caótica e contraditória que provoca, cria e mobiliza, nesta professora, a necessidade de engendrar possibilidades outras [por meio do café filosófico, esquemas conceituais e seminários]. Assim como é interessante salientar que as intervenções que ocorrem durante 0 desenvolvimento das propostas também compuseram 0 conjunto de intervenções didático-pedagógicas, por meio das interlocuções feitas por esta professora com seus escolares/estudantes, por conseguinte, as orientações os questionamentos, as correções, o acompanhamento dos registros e tarefas feitas pelos escolares/estudantes e afins, também concorrem para incorporar 0 movimento das situações vivenciais.

As situações vivenciais, por conseguinte, visam revelar os saltos qualitativos presentes nas atividades integradas, a fim de apresentar os fatos científicos existentes na realidade objetiva ${ }^{57}$. $\mathrm{Na}$ análise dos dados, apontam-se as evidências da integração entre o cognitivo, afetivo e o volitivo, para além da integração entre significados, interesses, desejos e sentidos, como expressão do movimento de apropriação do conhecimento teórico-filosófico, que impacta o desenvolvimento do pensamento por conceitos. Disto, é possível identificar situações vivenciadas no processo de ensino-aprendizagem que atribuem uma

\footnotetext{
57 Por representar os relatos do dia a dia da sala de aula, justifica-se o uso da primeira pessoa nessas situações vivenciais de ensino.
} 
qualificação ao nível da consciência dos estudantes e da professora no decurso da pesquisa.

Ademais, são as possibilidades ofertadas e vivenciadas que propiciam o movimento de transformação da qualidade de pensamento dos sujeitos, alterando o local existencial, dentro do processo, de escolares para o de estudantes, por exemplo. Nos processos de escolarização a racionalidade exacerbada separa o cognitivo do afetivo, não permitindo transformações qualitativas e, em conformidade com a teoria marxiana, é a integração entre as atividades e as funções superiores dada em meio à coletividade que impacta verdadeiramente o desenvolvimento dos indivíduos singulares, por isso, a atividade integrada em um ambiente coletivo, como o da escola, se mostra tão profícua.

Como supradito, a comunicação íntima-pessoal (ELKONIN, 1987) se estabelece como atividade principal para o jovem, em que a necessidade de pertencimento a uma determinada coletividade é de grande valia, neste período da vida humana. Assim, as ações voltadas para reproduzir a historicidade do coletivo, a fim de alavancar o desenvolvimento humano na práxis pedagógica nesta fase, podem propiciar momentos de viragem na formação dos sujeitos.

Salienta-se que a atividade de comunicação íntima-pessoal "[...] consiste em estabelecer relações com os seus pares, com base em certos padrões morais e éticos que medeiam as ações dos adolescentes" (ELKONIN, 1987, p. 120-121, tradução nossa), assim sendo, o sujeito inserido em uma dada coletividade precisa de uma mobilização quantitativa e qualitativa, que opere para além dos aspectos puramente objetivos, a fim de que ela se constitua em uma coletividade de estudos.

Nesta pesquisa, a utilização desta coletividade para a promoção de um ensino desenvolvedor constitui parte do piparote inicial a fim de garantir a objetivação dos princípios organizadores da intervenção didático-pedagógica, bem como dos procedimentos didático-pedagógicos.

Se nos processos de escolarização, faz-se preciso identificar qual é o ponto de partida e as expectativas para a aprendizagem, na integração entre a atividade filosófica e a atividade pedagógica, é preciso também, como supramencionado, atentar-se à constituição de uma coletividade de estudos, porquanto os sujeitos não são capazes de se alçarem à zona de 
desenvolvimento proximal, se não receberem a ajuda necessária para alavancar o seu desenvolvimento nesse sentido.

Entretanto, esta coletividade deve ser orientada pelo professor para não recair no erro construtivista de que o jovem é capaz de aprender sem ter em algum momento a orientação de alguém adequadamente habilitado para 0 ensino de determinados conceitos teóricos.

A teoria marxiana assinala que o sujeito se constitui a partir das relações interpessoais e das condições dadas pela realidade concreta. $O$ ser humano se constitui por meio da laboração da cultura, que impacta a natureza e, concomitantemente, o próprio homem. Nesse processo, ele produz e transforma a sua realidade e a si mesmo, tendo a possibilidade de desenvolver e formar seu psiquismo, pois é o social que medeia a formação e o desenvolvimento da psique humana. Assim sendo, a formação de uma atividade de estudo que se dê coletivamente, pode contribuir para o processo de desenvolvimento dos escolares em estudantes.

Sobre as categorias que serão utilizadas como procedimentos didáticopedagógicos, elas perfazem o constructo da metodologia pedagógica que se adequou para a atividade que se almejava mobilizar. Isso significa dizer que são categorias que buscam abalizar e fazer emergir do contexto escolar situações, que visaram promover a transformação das funções psicológicas dos estudantes. Tem-se que inicialmente os jovens participantes são apenas escolares, porque estão regularmente matriculados em um determinado momento da escolarização e que passam a ser estudantes quando entram em atividade de estudo (FREIRE, 2016).

Evidentemente, estas categorias serão adequadamente explicadas e explicitadas no decurso das situações vivenciais, com a intenção de mostrar a transformação do nível de consciência crítica, por meio da atividade filosófica integrada à atividade pedagógica. Contudo, cabe aqui apresentar sumariamente o que representarão no escopo da intervenção didático-pedagógica, os procedimentos didático-pedagógicos adotados, isto é, esquema conceitual, seminário e café filosófico.

O esquema conceitual é utilizado a priori, como instrumento de saída do tradicional texto transcrito na lousa, a fim de que os escolares/estudantes acompanhassem no transcurso das aulas expositivo-dialogadas a construção 
dialética do conhecimento teórico-filosófico e seu vínculo com o contexto social de seu tempo. Diz-se a priori, porquanto inicialmente estes apontamentos eram feitos tão somente por esta professora e acompanhados e/ou copiados pelos jovens, todavia, a posteriori estes foram mobilizados a fazê-lo de forma individual, para que depois fossem analisados pela professora.

O seminário, por sua vez, representava uma parte do processo e produto da atividade no contexto escolar. Ele era composto pelos principais conceitos filosóficos mediadores da atividade no decurso do bimestre, possuía um conjunto de regras previamente construídas coletivamente e para cada grupo de escolares/estudantes um conceito e/ou tema era sorteado e/ou escolhido por meio de um debate. Este seminário para além de ter uma estrutura formal, com trabalho teórico escrito autoral e apresentação por meio de cartaz e/ou powerpoint, poderia ser composto por intervenções culturais, tais como, apresentações com vídeos de cunho filosófico, intervenções artísticas na sala de aula e/ou na/para a escola, saraus, peças de teatro e afins.

O café filosófico, por seu turno, representava o processo de autoavaliação de um determinado período de aulas [que poderia ser bimestral ou mensal], em que professora e estudantes analisavam a qualidade das tarefas feitas e conceitos apropriados. Era também a expressão de um momento desinteressado no mote gramsciano, pois, por meio de uma conversa acerca da produção realizada no transcurso de um dado período, o café poderia ser tomado de maneira biológica e psicológica por todos [para comer de seu café e debater temas filosóficos, tanto os estudados no período, quanto possíveis indicações para o próximo bimestre]. O café filosófico se constitui em um importante momento de viragem e eixo motriz das situações vivenciais.

Algumas categorias, instrumentos, ações e operações dos procedimentos didático-pedagógicos se mostram como substanciais para a objetivação de um ensino que se pretende transformador. Nisso, a integração entre a atividade pedagógica e a atividade filosófica, em que se considere a integração entre o cognitivo, afetivo e o volitivo, é primordial para alavancar a constituição de uma atividade de estudo que seja coletiva, a fim de possibilitar a adequada mediação do conhecimento teórico, sobretudo, em que se pese considerar a atividade principal dos jovens na fase analisada. 
É preciso salientar que a sistematização para a execução dos procedimentos didático-pedagógicos era assistida para além dos muros da escola e para isso a professora contava com a ferramenta das mídias e redes sociais a fim de monitorar e orientar o andamento das tarefas, bem como sanar possíveis dúvidas.

Para além disso, é válido explicitar que os indicadores de desenvolvimento dos escolares em cada procedimento didático-pedagógico podem se expressar mais em um do que em outro, isso dependendo das características do procedimento adotado em cada situação vivencial de ensino, por isso, serão destacadas as características destes procedimentos no decurso das atividades integradas em sala de aula e porque um impacta mais do que 0 outro em cada situação.

Destarte, as situações vivenciais buscam evidenciar o processo de não objetivação e a objetivação do ensino, do estudo, da aprendizagem e do desenvolvimento por meio das categorias supracitadas, apresentando o seu movimento, os processos de crise, caos e/ou de transformação dos escolares/estudantes.

É importante notar que, no decurso das situações vivenciais, será apresentado como mobilizar a Zona de Desenvolvimento Proximal, em termos práticos, haja vista que a professora contribui para o avanço de um nível ao outro no processo de aprendizagem e de estudo dos escolares/estudantes. Ademais, o modo de construção e execução destas situações vivenciais é a representação do luto que torna-se luta para uma cavaleira-professora-proletária que cria, por si e para si, uma maneira de sobrelevar o que lhe dói, a ausência de atividade, práxis e revolução na escola.

Por consequência, são apresentados a seguir as situações que foram significativas para a intervenção didático-pedagógica, no sentido de impactar intencionalmente o desenvolvimento psicológico dos jovens. Sendo assim, cada situação vivencial, a título de exemplificação, apresentará um procedimento didático-pedagógico. 


\title{
4.3.1 Situação Vivencial 1: Esquema conceitual
}

A adolescência, por ser uma fase permeada de crises, caos e contradições, tem como atividade anterior à atividade de estudo e está próxima de uma atividade vinculada ao âmbito profissional, assim, precisa de uma condução que seja cuidadosa com suas especificidades, ainda mais levando em consideração a índole esquizóide deste período (VIGOTSKI, 2006).

Diz-se esquizóide dada a dinamicidade caótica, dialética e contraditória do desenvolvimento na adolescência. Vigotski, analisando uma investigação realizada por Zarogoviski, revela que

\begin{abstract}
Em alguns casos, a negatividade é notavelmente estável. O escolar ignora a família, não obedece aos adultos, é excessivamente animado na escola, ou ao contrário, muito desanimado e desajeitado, ou seja, é fácil encontrar nele traços de caráter esquizóide. [...] Entre as meninas, os traços negativos violentos são atenuados muito mais cedo do que nos meninos. Ao caracterizar essas crianças, o autor da pesquisa reconhece que o período inicial de maturação sexual tem um curso difícil e agudo. (VIGOTSKI, 2006, p. 34-35, tradução nossa).
\end{abstract}

Na Paidología del Adolescente, Vigotski (2006) assinala por meio de pesquisas realizadas por outros autores que, na maturação sexual, os indivíduos se apresentam ora como violentos, ora apáticos, ora desajeitados, ora centrados em tarefas específicas de grande valor aos seus pares. Ele assevera exemplificando que

Não devemos esquecer, diz Kretschmer, que os afetos normais no período de desenvolvimento sexual, timidez, falta de jeito nos movimentos, sentimentalismo, excentricidade patética, estão intimamente relacionados a alguns traços temperamentais dos esquizóides (VIGOTSKI, 2006, p. 185, tradução nossa).

Considerar que características, tão marcantes como as da adolescência, impactam no ambiente escolar, é passo importante para a organização de um tipo de ensino que conduza adequadamente o comportamento e o desenvolvimento dos jovens, mobilizando a formação de determinadas funções psicológicas superiores, por meio da apropriação cognitiva e da constituição do vínculo afetivo [na integração de ambos com os interesses, volições e vivências]. 
Outro ponto a ser considerado é que a análise do desenvolvimento coletivo da turma é de suma importância para dar corpo à integração de atividades [a pedagógica e a filosófica]. Evidentemente que, a priori, não são todos os escolares que são impactados por esta intervenção, o que faz que o apontamento da participação da coletividade dos jovens seja dada pela marca dialógica e dialética escolares/estudantes, tendo em vista que na turma existem aqueles que são escolares porque estão apenas em processo de escolarização, ou porque estão em direção ao ser estudante, bem como àqueles que estão incorporando práticas da atividade de estudo [mesmo que de modo inconsciente] e, por isso, há a potência de ser estudante ali.

No decurso do ano letivo é possível constatar que os escolares/estudantes são afetados pelo processo pedagógico de diferentes formas, afinal de contas, a adolescência é a fase da transição em sie para si e a complexidade de seu desenvolvimento está diretamente vinculada a quem este adolescente tem vínculos. Quando se assinala a análise do desenvolvimento coletivo da turma é porque foram considerados os traços comuns entre os estudantes de uma mesma turma, ou seja, quais as aprendizagens já foram consolidadas e quais merecem retomada e/ou atenção para que sejam objetivadas por meio das atividades integradas em sala de aula. Segundo assevera Sforni (2015, p. 383), a Zona de Desenvolvimento Próximo da turma visa

[...] identificar os conhecimentos e capacidades que são comuns à turma, as aprendizagens que, de modo geral, já estão consolidadas e as que merecem investimento. $O$ desenvolvimento de cada criança é singular, no entanto, há traços comuns entre estudantes de uma mesma sala de aula. [...] os estudantes de uma sala estão envoltos em uma mesma cultura na escola e na comunidade e partilham de um histórico semelhante.

A elaboração do plano de ensino e de aula exigiu da professora perscrutar, concomitantemente, a individualidade e a coletividade. Por isso, reitera-se a denúncia de que não há como se ter uma organização homogênea de conteúdo, temas, conceitos e categorias para se ensinar a Filosofia, dada a especificidade de cada contexto e os currículos deveriam prever isso.

$E$ foi por meio de uma tarefa de sondagem inicial que esta professora pôde, de fato, reorganizar o conteúdo do Currículo da Seduc-SP sem, no 
entanto, prejudicar o direito de os jovens terem acesso às aprendizagens determinadas pelo documento e pela lei, como supradito. Para além disso, havia a necessidade de sair do lugar comum, para conduzir o trabalho com este conteúdo reorganizado, um fio condutor, para que a situação vivencial fosse uma ação desencadeadora de aprendizagem. Assim, um dos eixos motrizes que constituíram a unidade didática com a intenção de transformar os escolares em estudantes foi apresentar a história da Filosofia como promotora do desenvolvimento do humano no homem.

Um dos procedimentos didático-pedagógicos utilizados foi o esquema conceitual, que inicialmente era elaborado pela professora e transcrito na lousa no decurso das aulas. Este esquema contava com a explicitação de conceitos e categorias e buscava mobilizar a participação dos jovens que, com o tempo, passaram a contribuir, apontando suas considerações acerca dos temas/conteúdos/conhecimentos abordados.

O esquema conceitual visava, deste modo, propiciar ao estudante a experiência de transcrever para o seu nível de consciência o conteúdo de uma aula expositiva-dialogada ou mesmo transcrever algumas anotações feitas pela professora na lousa.

Porém, para colocar esta estrutura em andamento, é preciso salientar, a partir do mote cartesiano, que os jovens foram informados ainda no início do ano letivo acerca do contrato pedagógico, das normas e regras, sobre a estrutura das aulas de forma clara e distinta. O que não consiste em cristalizar ações, mas em indicar inicialmente ao escolar/estudante quais seriam as regras do jogo de que ele iria participar, apontando que estas regras não seriam fixas e que poderiam contar com a colaboração dele. É evidente que, sempre que preciso, este contrato pedagógico era repetido e renovado, tendo em vista que, durante o ano letivo, houve abertura para que os estudantes/escolares fizessem alterações nele, em conformidade com suas expectativas e interesses de estudo.

Desta forma, a primeira aula foi utilizada para a professora apontar como se estruturariam, de forma geral, as aulas, os trabalhos e avaliações, assim como as regras para conduta. A professora pontuou também sua disponibilidade para com os escolares/estudantes, para além do horário das aulas por meio das redes sociais e do e-mail institucional (“@prof.educacao.sp.gov.br”), a fim de que todos 
que sentissem necessidade e/ou vontade pudessem tirar dúvidas por estes meios [mesmo que fosse de maneira coletiva ou individualmente].

A respeito da estrutura geral das aulas, ela contava com uma estrutura que contemplava o Currículo reorganizado, por meio de uma aula expositivodialogada, a apresentação do esquema conceitual, com o tema central e tarefas desafiadoras, para serem resolvidas em sala de aula ou a posteriori. As tarefas podiam ser apontadas, por meio de uma pergunta mobilizadora para o estudo, a partir do material da Seduc-SP, das reflexões suscitadas em sala de aula, ou mesmo dos exercícios propostos em sala de aula.

Figura 1. Exemplo de esquema conceitual na lousa

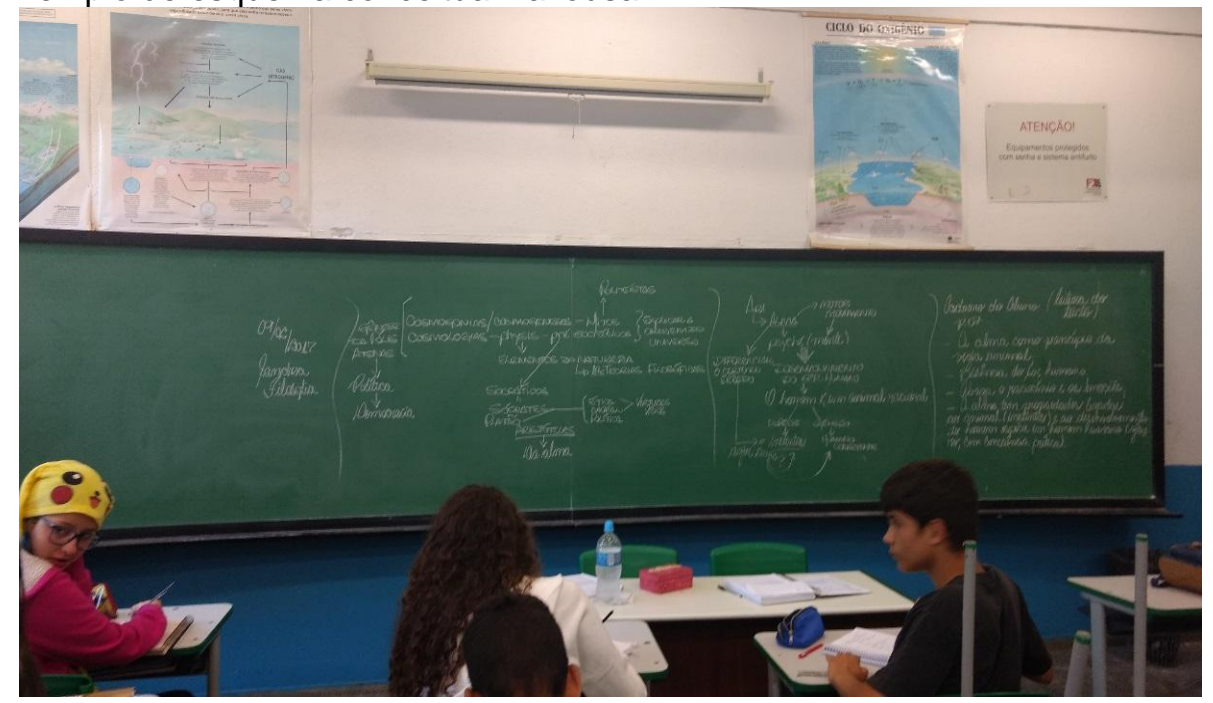

Explicitação dos temas da aula por meio de um esquema conceitual de Filosofia na 1 a série do Ensino Médio elaborado pela professora e proposição de resolução de exercícios do Caderno do Aluno da Seduc-SP

No ano desta intervenção pedagógica, 2017, havia um problema de ordem estrutural nas escolas estaduais da Seduc-SP, porquanto as respostas para os exercícios do Caderno do Aluno daquele período estavam disponíveis em diversos sites [o que ainda persiste de certa maneira]. Para tentar contornar o problema, a professora escolhia alguns dos exercícios do Caderno do Aluno [cuja intencionalidade convergia para o objetivo da aula] e instigava os escolares para que aqueles fossem solucionados coletiva e instantaneamente pela turma em voz alta [oralmente], por meio de uma reflexão que contasse com a fala dos próprios jovens e buscou assegurar que, inicialmente, esta, ao veicular aquela, não precisava contar necessariamente com um refinamento filosófico [mas 
precisava, ao menos, estar direcionado à elaboração de uma reflexão crítica, mesmo que fosse preciso o auxílio da professora nesse momento].

O mesmo passou a valer para as anotações nos cadernos pessoais dos escolares/estudantes. A intenção era dar segurança ao jovem para se expressar da maneira como sabia, para aí sim promover uma adequação de sua linguagem para a linguagem filosófica no transcurso das aulas. Esta também foi a orientação para as leituras coletivas, debates, exposições de dúvidas e falas no durante as aulas, pois a intenção era a de mostrar a importância de cada colocação feita pelos escolares/estudantes.

Figura 2. Registro de um escolar/estudante

$11 / 04 / 2017$

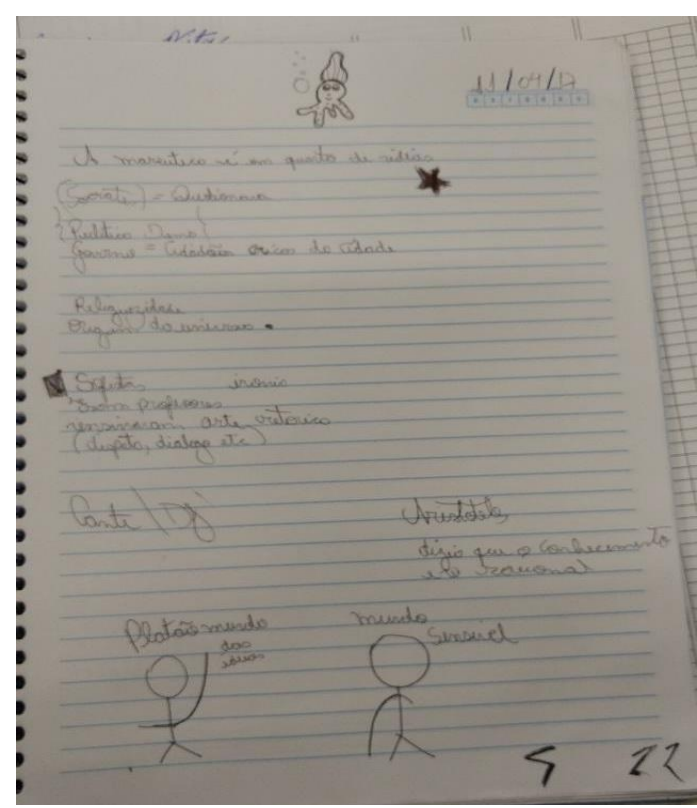

Nota-se que na representação gráfica dada pelos "bonequinhos", para expressar que o filósofo Platão tinha vínculo com uma racionalidade, que este privilegiava o mundo das ideias e da abstração, este está representado por um "bonequinho" que está apontando para cima, e que o "bonequinho" do filósofo Aristóteles está apontando para baixo, para indicar sua relação com o mundo empírico

Responder, falar e anotar de forma pessoal inclusive foram pontos de partida considerados propícios para a constituição de um pensar filosófico exordial, pois, para além de os temas da $1^{1} \stackrel{a}{ }$ série serem reorganizados, de modo a trabalhar a passagem do senso comum ao conhecimento teórico, e para que se promova nesse trabalho a caminhada em direção à atividade filosófica, é interessante trabalhar a apropriação de um determinado conhecimento, de modo que sua internalização perpasse uma interpretação primeira, que seja inteiramente subjetiva e afetiva. 
É válido salientar que é na $1^{\underline{a}}$ série do Ensino Médio que muitos escolares/estudantes têm pela primeira vez o contato com a Filosofia e é de suma importância que este contato ocorra de maneira especial. Desta feita, a passagem do concreto ao abstrato e do abstrato ao concreto pensado pode ocorrer sem pressões desnecessárias, sem academicismos incoerentes ${ }^{58}$ com este momento da aprendizagem, uma vez que o importante é caminhar com o escolar/estudante, para que ele atribua o mesmo sentido e significado, que o professor, a esta nova situação vivencial.

A intencionalidade do professor que trabalha desta maneira se orienta para fazer com que o escolar/estudante consiga se apropriar de um conceito teórico, no seu tempo, e a partir de seu repertório cultural, sem que se sinta inferiorizado ou constrangido. Outra intenção é mostrar o processo de constituição de um tipo de conhecimento, acerca da realidade empírica, que é transformado e alçado a outro de nível qualitativamente superior, a saber, passar de um pensamento que se constitui inicialmente raso, ao pensamento teórico, por meio da reflexão crítica no desenvolvimento das funções psicológicas superiores. Deste modo, cada procedimento didático-pedagógico visou orientar o escolar ao que é ser estudante e promover sua passagem para esse nível.

E foram as intervenções e os vínculos sociais formados a partir dos apontamentos feitos por eles nas leituras coletivas, debates, exposições de dúvidas e falas no decurso das aulas, que propiciaram o fortalecimento do sentimento de pertencer a uma coletividade. Ademais, foi por meio da fala do outro e da própria fala que os jovens puderam reconhecer a unidade da turma para formação de grupos de estudos para as tarefas, não somente as que tipicamente seriam feitas em grupo, mas a maioria, de forma geral.

Destarte, no movimento de integração da atividade filosófica à atividade pedagógica, cada uma das manifestações dos jovens interessa, pois elas expressam a constituição do seu movimento para com relação aos estudos, tanto

\footnotetext{
58 Isso não significa dizer que é preciso abandonar a gênese dos conceitos teóricos, ao contrário. Se faz necessária a adequação da linguagem filosófica, em um primeiro momento, a fim de transpor para a compreensão dos jovens o que quer comunicar à Filosofia, assim, o professor poderá orientar o desenvolvimento dos escolares/estudantes de forma a superar, pouco a pouco, suas acepções iniciais da realidade concreta e da teoria, para formas mais elaboradas de compreensão e até mesmo de crítica do mundo que o cerca e da cultura que permeiam os sujeitos.
} 
no que concerne ao aparente, quanto ao que pode estar oculto. Um jovem que não realiza uma tarefa proposta em sala de aula pode sinalizar inúmeras coisas, cabendo ao professor estar atento a estes e outros sinais dados.

Por isso, há a necessidade de manter em dia e em ordem a correção das tarefas, de averiguar os registros dos jovens em seus cadernos pessoais, de analisar a conduta destes, quando inseridos na coletividade de estudos, ou no ato de ter de estudar individualmente, e nas relações que mantém com seus pares, com a professora e consigo mesmos neste processo de escolarização.

A análise das respostas dadas pelos escolares aqui se concentra não exatamente no certo ou no errado, mas em como os escolares/estudantes se expressam verbalmente e, a posteriori, como elaboram seus textos, isto é, na tendência que apontam em tentar ou não entrar em atividade de estudo. É pertinente destacar que a princípio nem todos os escolares/estudantes participam ou entregam as tarefas, mas isso também é um aspecto que manifesta uma necessidade que precisava ser acompanhada e examinada minuciosamente.

Em uma dessas situações, inclusive, a professora ao observar que um dos escolares/estudantes não entregava as tarefas e que ele não fazia os apontamentos em seu caderno pessoal, o inquiriu do porquê, ao passo que o escolar respondeu que "as palavras da matéria eram muito esquisitas e que ele não as compreendia, e que por isso não via qual a necessidade de anotá-las e que não participava das aulas pelo mesmo motivo, além do que, tinha vergonha de falar alguma palavra de forma errada e os colegas tirarem sarro (Anotação acerca do acompanhamento dos escolares/estudantes na sala de aula, caderno pessoal da professora, 21/02/2017).

A princípio um relato deste poderia ser tomado como um fator menor, descomprometimento, uma justificativa torpe ou uma estratégia discursiva similar de natureza evasiva, entretanto, ele diz muito. Isso porque a situação aponta alguns impeditivos ao escolar para entrar em atividade de estudo; serão apontados três. O primeiro é o distanciamento do conhecimento teórico, da realidade linguística apropriada pelo escolar/estudante. O segundo, a ausência de articulação entre significado e sentido dos estudos, para apropriação desse novo componente curricular. E o terceiro, o peso da coletividade para sua participação nas situações e tarefas em sala de aula. 
Sawaya (2008) aponta que a escola faz uso de uma linguagem, em seus modos de ensino, que não corresponde ao desenvolvimento atual dos estudantes das classes populares. E em vez de introduzi-los nesse universo de significados, desqualifica-os, por meio do preconceito, atribuindo um valor negativo às expressões regionais dos escolares.

[...] a escola estabelece relações inibitórias entre professor e aluno, que geram dificuldade de comunicação - o que leva as crianças a não perguntar o significado das palavras que eles não entenderam. Além disso, as ignorâncias dos diferentes estilos linguísticos entre os vários grupos da sociedade levam a considerá-los como deficiências. (SAWAYA, 2008, p. 874).

Assim, como supramencionado, a intenção exordial foi aproximar os escolares/estudantes dos conceitos teóricos a partir de suas experiências e formas de expressão primeira para então, pouco a pouco, orientá-los em direção à atividade, para que pudessem transformar suas concepções advindas do senso comum em conhecimento teórico apropriado no decurso do tempo, bem como ter certa segurança para se comunicarem no espaço escolar, fortalecendo seus vínculos afetivos e fazendo com que eles utilizassem, de maneira mais positiva, a sua atividade principal, a atividade de comunicação íntima-pessoal.

Segundamente, a partir da possibilidade da apropriação do conhecimento teórico-filosófico, de uma consciência arrazoada, crítica e atenta acerca da realidade concreta, pressupõe-se também orientá-los de tal forma na situação vivencial que eles consigam ter um olhar que vá ao cerne das questões, hipóteses, situações, objetos, contextos e afins.

Destarte, a educação escolar, voltada para a socialização deste tipo de conhecimento, visa mediar a gênese dos conceitos e ir à raiz, para empreender processos que mexam com os nexos-causais. Conforme Freire (2016), a apropriação dos nexos internos dos conceitos teóricos elaborados sóciohistoricamente na atividade pedagógica favorece um processo de formação privilegiado na aprendizagem desses conceitos teóricos em sua máxima elaboração.

Vigotski (2006), analisando a pesquisa feita por Potebnia, aponta a importância da apropriação dos conceitos teóricos, bem como dos mecanismos da linguagem e de suas significações, para o desenvolvimento do pensamento conceitual. A linguagem, a palavra, a ideia, o conceito não criam a realidade, 
mas contribuem para melhor compreendê-la e, sobretudo, também para que o indivíduo possa compreender melhor a si mesmo. Vigotski (2006) afirma que se

\begin{abstract}
Acreditamos ser inteiramente correto comparar o estudo do pensamento conceitual - como fator de desenvolvimento da personalidade e de sua relação com o mundo circundante - com a tarefa que a história da linguagem impõe. A. A. Potebnia considerava como tarefa fundamental da história da linguagem mostrar de forma prática como a palavra participa da formação de uma série sucessiva de sistemas que abrangem a atitude da personalidade para com a natureza. Em geral, entenderemos corretamente o significado desta participação se admitirmos a seguinte tese central: a linguagem não é o meio de expressar uma ideia já formada, mas de criá-la, não é o reflexo de uma concepção já estruturada do mundo, mas a atividade que a forma. Para apreender a própria dinâmica espiritual, para compreender as próprias percepções externas, o indivíduo deve objetivar cada uma delas em palavras e relacioná-las com outras palavras. Para compreender a natureza externa e a sua própria natureza, é importante saber como vemos essa natureza, por meio da qual comparações seus vários elementos se tornam perceptíveis à mente, até que ponto eles são autênticos para nós. (VIGOTSKI, 2006, p. 73, tradução nossa).
\end{abstract}

Chega-se aqui ao terceiro ponto, em que, no contexto escolar, a passagem do em si ao para si pode ser favorecida pelas mediações simbólicas, que favorecem a aproximação do indivíduo das máximas possibilidades do gênero humano. Vigotski (2000b) aponta a adolescência como um importante momento do desenvolvimento humano e usa a tese de Hegel sobre o ser em si e o ser para si a fim de mostrar como se dá o movimento de formação do homem como indivíduo humano. Sobre Hegel assevera que:

[...] Ele dizia que todas as coisas existem, de início, em si, mas que com isso a questão não se esgota e no processo de desenvolvimento o ser em si se transforma em ser para si. O ser humano, dizia Hegel, é uma criança cuja tarefa não consiste em permanecer no abstrato e incompleto em si, mas sim em ser também para si, isto é, converter-se em um ser livre e racional. (VIGOTSKI, 2000b, p. 199).

Considera-se, portanto, que, nesta intervenção didático-pedagógica, as atividades integradas propõem um ensino e uma aprendizagem para si, posto que criam condições para a transformação das estruturas psíquicas dos sujeitos, por meio da apropriação dos bens culturais, da compreensão do modus faciendi humano, forjado na elaboração do conhecimento teórico-filosófico, o qual pode colaborar com o desenvolvimento das funções psíquicas superiores dos 
escolares/estudantes, sobretudo na formação do pensamento por conceitos, da consciência crítica, do pensamento abstrato e dialético.

Todavia, para empreender este movimento em sala de aula, alguns procedimentos, ações e operações são necessários. Afinal de contas, para integrar a atividade filosófica à atividade pedagógica, faz-se preciso a intencionalidade e a sistematização consciente, de que o processo é caótico, dialético e contraditório. Assim, neste momento da situação vivencial, os escolares/estudantes vão, por procedimentos mediados, lentamente, compreendendo o que é participar de uma aula de Filosofia, em que se é possível produzir Filosofias, ou como diria Gramsci (1999) observar que "todos são filósofos".

Figura 3. Registro de um escolar/estudante $17 / 08 / 2017$

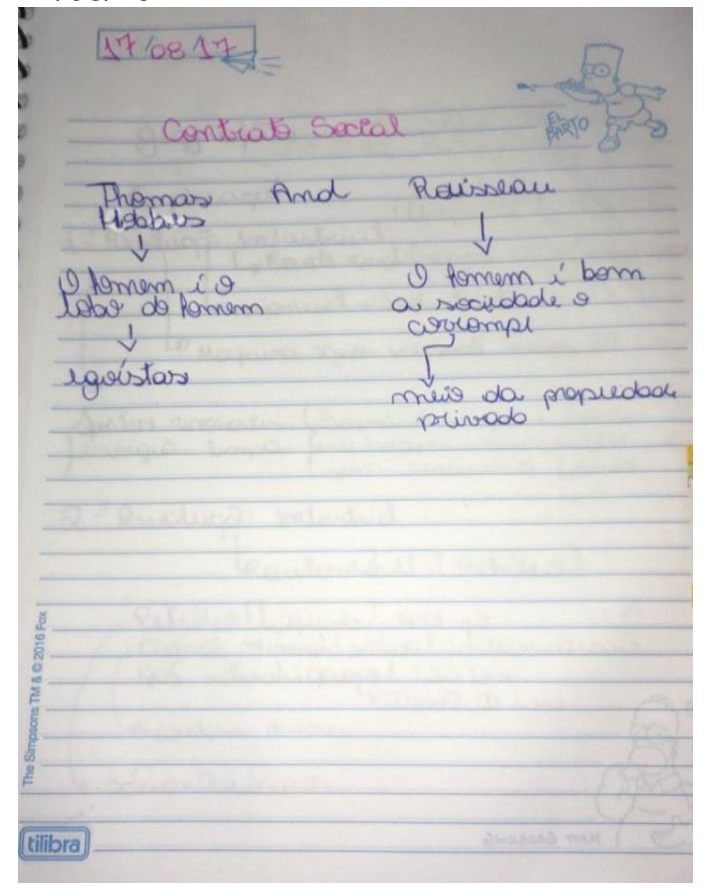

Apontamento sucinto feito a partir de uma aula expositiva-dialogada em que não houve por parte da professora o esquema-conceitual na lousa, porém, por iniciativa do escolar/estudante, resolveu ele próprio fazer a síntese da aula valendo-se do esquema-conceitual como mecanismo de registro de aula. No esquema conceitual de autoria do escolar/estudante, ele faz sua síntese acerca da filosofia de Hobbes e Rousseau, indicando seus principais "pensamentos".

Como foi apontado no capítulo anterior, retomamos Vigotski (2006, p. 66), quando o psicólogo soviético assinala que o jovem passa a relegar certos conhecimentos concretos e começa a se interessar por componentes curriculares que requerem conhecimentos mais abstratos como, por exemplo, as questões filosóficas, políticas, a música, a arte, matemática e física, mesmo que não domine tanto o assunto. Isso se dá porque, como o próprio autor afirma, neste período ainda não é possível se dominar o pensamento abstrato e 0 
pensamento dialético por completo, dada a formação inicial do pensamento conceitual.

Vigotski (2006, p. 67-68) ainda aponta a presença do espírito de contradição que se manifesta no conteúdo do pensamento do adolescente; 0 que é muito provável pela concomitância da formação de funções psicológicas superiores interfuncionais, como o pensamento por conceitos, a consciência crítica, o pensamento abstrato e o pensamento dialético, que estão intimamente ligados à afetividade, aos interesses e à volição, desde que eles sejam adequadamente mobilizados. Vigotski (2006, p. 67) afirma que:

\begin{abstract}
Na opinião de Blonski, o intelecto do adolescente se distingue por sua propensão para a matemática, embora se diga que os adolescentes não os assimilam facilmente. Em apoio à sua tese, Blonski alega sua experiência de ensino; considera que entre as idades de quatorze e dezessete é quando mais estudam a matemática na prática escolar, que é precisamente nos anos em que se adquire o conhecimento fundamental para a formação matemática. Na mesma idade, os adolescentes são muito atraídos pela física, é também a idade dos interesses filosóficos e consequentemente do raciocínio lógico (VIGOTSKI, 2006, p.67, tradução nossa).
\end{abstract}

É importante notar no registro acima que, segundo os apontamentos do caderno pessoal da professora, o escolar/estudante elaborou o esquema conceitual por si e para si, a partir de um caminho que ele trilhou por meio de sua apropriação pessoal do conhecimento teórico-filosófico; até mesmo por isso, a observação da anotação foi tão marcante para a professora, que ficou extremamente orgulhosa com o poder de síntese do escolar/estudante. Uma síntese simples e, concomitantemente, de ordem complexa.

Ele fez o registro de dois filósofos, Hobbes e Rousseau, um tema da aula em 17 de agosto de 2017, indicando seus principais pensamentos. Enquanto para o escolar/estudante, o primeiro filósofo afirmava que o "homem é o lobo do homem" e, em sua anotação, isso traz uma consequência egoísta, o segundo filósofo, em seu pensamento político, afirmava que "o homem é bom, a sociedade que o corrompe", e para o escolar/estudante isso criava um meio para a propriedade privada.

A diferença do registro do escolar/estudante que fez os bonequinhos (uma representação gráfica de dois filósofos) que apontavam para cima e para baixo, para este que o pensamento foi organizado por meio de palavras não pode ser 
de que um é melhor do que o outro, mas sim que houve uma aprendizagem possível de se apropriar em um momento e que no decurso da situação vivencial houve uma aprendizagem de qualidade outra, mas que em ambos momentos da situação vivencial ele estava aprendendo e se apropriando do conhecimento teórico, só que, como dito acima, da forma que lhe era possível.

Por isso, é interessante criar na sala de aula o tempo todo, para além das regras do contrato pedagógico, do sistema de aproximação, por meio de rede social, uma ambiência de segurança, de afetividade, como predito, para que o escolar/estudante possa se expressar como the é possível, e o professor possa acompanhar o nível de desenvolvimento real de cada jovem no momento em que está acontecendo [durante o processo].

Considerar o afetivo neste processo pode inclusive favorecer a percepção de manifestações outras por parte dos estudantes/escolares. Um exemplo é que, ao final do bimestre, um dos adolescentes aparentava estar mais nervoso do que os demais por ocasião da primeira prova bimestral. Ao notar o comportamento inquieto do jovem, esta professora foi até ele perguntar se ele não queria lavar o rosto e/ou tomar uma água, ao passo que ele pediu para lhe falar algo ao pé-doouvido, momento em que era perceptível certo constrangimento, por parte do escolar/estudante. A frase era "o que a senhora faria se pegasse alguém com uma cola na prova", ao passo que a resposta foi em tom baixo "que ela seria anulada"; o jovem pediu então para, antes de iniciar a prova, que ambos fossem até o lado de fora da sala de aula e ele entregou um papel dobrado em quatro partes (Anotação acerca do acompanhamento dos escolares/estudante na sala de aula, caderno pessoal da professora, 04/2017). 
Figura 4. Registro do estudante

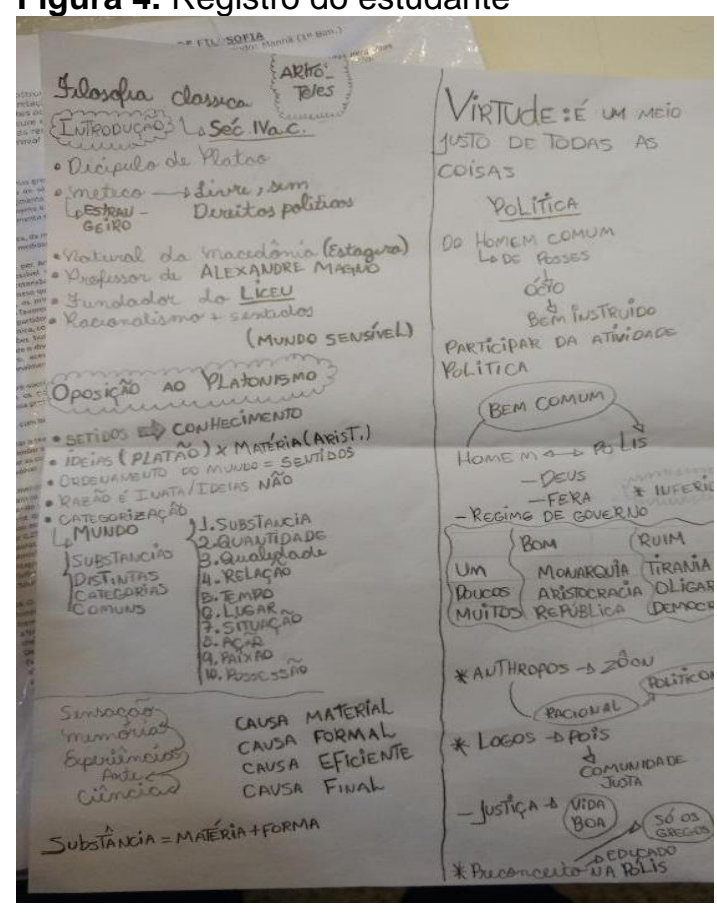

Neste "papel dobrado" o estudante/estudante faz a síntese da filosofia de Aristóteles e Platão. Há menção das principais teorias acerca do conhecimento, lógica, ética e política de ambos os filósofos.

O papel dobrado tratava-se de uma cola que o adolescente havia feito para utilizar durante a prova, mas, segundo o relato dele, portar aquele papel estava deixando-o ainda mais nervoso do que o necessário e que, além do mais, ele tinha feito tantas versões da cola que não precisava mais dela e que confiava o suficiente na relação que tinha com a professora para lhe falar a verdade, a ponto de abrir mão da cola mesmo sabendo das possíveis sanções previstas no contrato pedagógico, caso a professora julgasse ser preciso, o jovem ainda assinalou que ele tinha consciência de seu erro e que ele queria ser ético, como ele tinha aprendido nas aulas de Filosofia. Há, desta forma, nesta ocorrência, a demonstração de apropriação do conceito - teórico e prático -, porquanto o jovem percebeu a contradição implícita no comportamento de burlar a avaliação do próprio conhecimento.

Nessa ocasião, é notável a presença da apropriação de uma consciência tal, que encaminhava este jovem escolar para se tornar um estudante, uma consciência que não foi desenvolvida como produto do medo ou da memorização de um conjunto de regras. Houve a integração da cognição, da afetividade, do interesse, da volição e das vivências na situação vivencial para a formação deste ato consciente, que representa também o desenvolvimento de suas funções psicológicas superiores. 
O jovem, na apropriação do conhecimento teórico-filosófico e do contrato pedagógico firmado, a partir de vivências anteriores em sala de aula com aquela professora, sentiu-se seguro o suficiente para admitir um erro, ou melhor, no transcurso de uma dada situação teve consciência de que o fato de portar uma cola e ser pego poderia ser prejudicial a ele e decidiu deliberadamente por entregá-la, mesmo que isso incidisse em uma penalidade, afinal de contas ele poderia também não ser pego.

Analisar os adolescentes em sua integralidade, reorientar suas condutas, os sentidos e os significados que atribuem aos estudos e à escola, validar suas formas de expressão, examinar de modo pormenorizado seus interesses, desejos, volições, vivências e conhecimentos prévios são ferramentas riquíssimas para pôr a atividade filosófica e a atividade pedagógica na práxis dos processos educativos.

E para atender as necessidades desses adolescentes foram elaborados os procedimentos didáticos pedagógicos adequados ao contexto e à realidade deles. O esquema conceitual contribuiu de maneira a provocar saltos qualitativos na aprendizagem, na apropriação dos conhecimentos teóricos-filosóficos e no desenvolvimento das funções psicológicas superiores. O seminário, situação vivencial que será apresentada a seguir, teve a mesma intencionalidade, formando parte do constructo para alavancar os avanços e permitir a organização desta fase, indicada como contraditória e caótica de acordo com a teoria vigotskiana.

\subsubsection{Situação Vivencial 2: Seminário}

O seminário, enquanto procedimento didático pedagógico, tinha objetivo e regras específicas para cada bimestre, haja vista que além de ter uma necessidade que precisava ser atendida, seja a que fosse dada pelo Currículo, seja a que fosse dada pelos escolares/estudantes, seja a que fosse dada pelos conteúdos, conceitos e temas que foram reorganizados por esta professorapesquisadora, havia também a mudança na forma de apresentação desta tarefa. Contudo, havia aspectos que sempre eram mantidos. 
O seminário, destarte, para além de ser uma situação vivencial que tinha uma poderosa estratégia de ensino e aprendizagem, por sua complexidade multifacetada, pois se tratava de uma atividade de estudo formativa (DAVIDOV; MÁRKOVA, 1987b) coletiva, também era um excelente instrumento de avaliação, porquanto possibilitava à professora avaliar a qualidade e o tipo de apropriação dos conceitos teóricos-filosóficos empreendida pelos escolares/estudantes.

Era estratégia porque era um meio eficaz e eficiente que visava objetivar uma determinada meta ou alguns objetivos, cabendo, portanto, à professora sistematizar, antes do seminário mecanismos, ações e operações para que o conhecimento teórico-filosófico se tornasse mediador das relações intrínsecas a este processo.

Em outras palavras, era preciso que o seminário não se tornasse um fim em si mesmo, ou uma transferência automática de uma função que era da professora aos escolares/estudantes. Assim, todos os assuntos, conteúdos, conceitos e temas eram abordados antes pela professora, responsável pela apresentação que ia à gênese destes, no decurso das aulas, por isso, inclusive, o esquema conceitual era tão importante também neste processo, posto que tinha a função de ser um meio para a promoção da aprendizagem e do desenvolvimento dos escolares/estudantes que poderia ser objetivado neste momento da situação vivencial.

Era um instrumento de avaliação porque conseguia integrar as estratégias aos aspectos tradicionais e à prática de uma tarefa escolar. Os aspectos tradicionais podem ser descritos como a produção de um texto e de uma apresentação sumária do assunto por meio de cartazes ou de um programa de criação, edição e exibição gráficos; a prática é o planejamento que tinha que ser realizado pelos escolares/estudantes, a fim de selecionar e organizar adequadamente os assuntos para elaborar a síntese que seria usada na exposição oral do tema (subsidiando-se ou não em um referencial teórico ou em sua própria perspectiva acerca do tema) ou na intervenção de cunho artísticocultural que considerasse o tema como base.

Só que, mais que isso, a necessidade do seminário nesta pesquisa era a de propiciar uma situação vivencial que incorporasse a atividade de estudo formativa à atividade de estudo coletiva, promovendo um momento de 
socialização em que os escolares/estudantes pudessem se vincular aos demais participantes do grupo do seminário, para pesquisar, debater, disseminar ideias e ideais, acepções e percepções acerca da relação dos assuntos estudados com a realidade concreta hodierna. Diz-se formativa porque "[...] o efeito sobre o desenvolvimento e a educação não é garantido por qualquer atividade, mas apenas pela atividade de estudo formativa" (DAVIDOV; MÁRKOVA, 1987b, p. 333, tradução nossa) e coletiva, para além do já mencionado, porque ao escolar/estudante cabe aprender e dominar as formas da atividade de estudo coletiva, para ser efetivamente sujeito da atividade e ter garantido a formação vinculada ao efeito do ensino desenvolvimental na atividade de estudo (FREIRE, 2016, p. 155).

O seminário, por conseguinte, visava mostrar aos sujeitos da situação vivencial, para além da reprodução da gênese dos assuntos, temas e conceitos estudados, ou melhor, da constituição histórica desses, dada por meio da elaboração sociocultural e em determinado contexto, as possibilidades de avanço na aprendizagem, por meio da integração da cognição e da afetividade aos interesses, desejos, volições e vivências, favorecendo, desse modo, a comunicação íntima-pessoal e, ao mesmo tempo, conduzindo os escolares/estudantes ao desenvolvimento próximo e à próxima atividade. Segundo Davidov (1988),

[...] o processo de apropriação leva ao indivíduo a reprodução, em sua própria atividade, das características humanas formadas historicamente. Durante a reprodução a criança realiza a atividade que é adequada (mas não idêntica) a atividade encarnada pelas pessoas nestas capacidades (DAVIDOV, 1988, p. 56, tradução nossa).

No que concerne às regras gerais para a elaboração do seminário, a professora explicitava que todos os itens que compunham as normas faziam parte da avaliação. A nota do seminário seria composta por: trabalho teórico, apresentação oral, cartaz ou apresentação em powerpoint. Estas regras gerais foram mantidas no decurso dos bimestres.

No que diz respeito ao trabalho teórico ele: 1 . Deveria ser entregue na data da apresentação do seu grupo; 2. Deveria ser autoral (ou seja, um trabalho de cunho dissertativo de autoria dos integrantes do grupo); 3. Deveria seguir algumas regras de normatização: Capa, Folha de Rosto, Resumo, Sumário, 
Introdução, Desenvolvimento do Conteúdo, Conclusão, Referência Bibliográfica; Fonte: Times New Roman ou Arial, Tamanho: 12 (conteúdo) e 14 (capa), Espaçamento: 1.5, Parágrafo: 1.25, Alinhamento: Justificado, Paginação: Canto Direito e Superior.

Sobre a apresentação oral, o grupo teria por tempo mínimo 12 minutos e máximo 20 minutos; e para a produção do cartaz solicitava-se duas cartolinas coladas na posição horizontal (uma embaixo da outra) ou para a apresentação em powerpoint que as lâminas deveriam ser enviadas para o e-mail institucional da professora ("@professor.educacao.sp.gov.br") antes da data de apresentação e, para além disso, o grupo deveria levar o seu instrumento para apresentação, no caso, o seu Notebook, ou solicitá-lo com antecedência para a equipe gestora da escola. Abaixo um exemplo de como essas regras chegavam aos estudantes/escolares:

Figura 5. Regras para o seminário na lousa

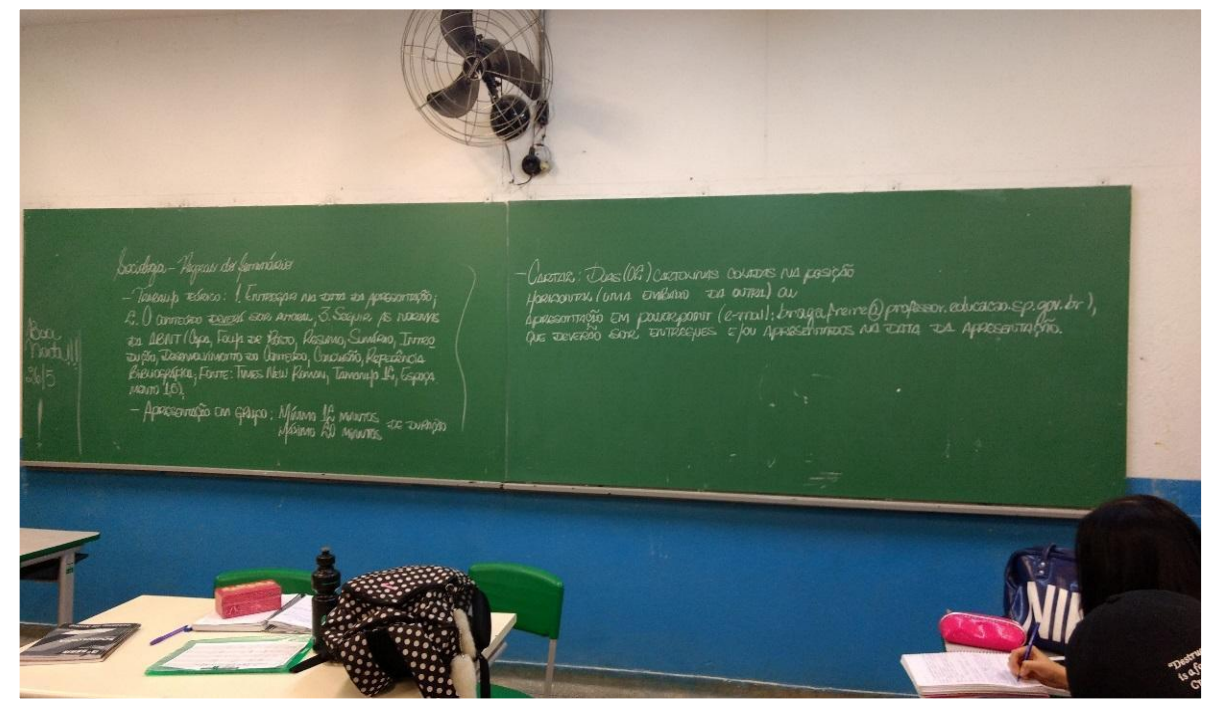

Regras para a elaboração de Seminário da 1ª série do Ensino Médio colocadas na lousa

É válido salientar que as regras do seminário e a forma de escolha dos temas não foram organizadas de forma aleatória ou espontânea, cada elemento possuía o seu porquê de existir. A decisão, por solicitar um texto autoral dos jovens, foi tomada para analisar a qualidade e a forma de apropriação dos conteúdos, conceitos e categorias, bem como quais eram os avanços e as dificuldades na fluência da escrita. 
Quanto à normatização dos trabalhos, o objetivo era que os estudantes aprendessem, na escola, que existe uma forma de execução de trabalho que é acadêmica, para além dos esquemas desenvolvidos no Ensino Fundamental da Educação Básica. É preciso apontar que esta professora conduziu os estudantes/escolares à sala de informática da unidade escolar para mostrar na prática o como fazer, assim como enviou alguns tutoriais explicativos nas redes sociais deles.

No que diz respeito aos prazos solicitados e acordados, tempo para apresentação, formato de cartaz e possível solicitação de equipamentos para a equipe gestora da escola, evidencia-se a aprendizagem da gestão de tempo e da assunção de responsabilidades, para que o grupo conseguisse se organizar de maneira adequada, a fim de alcançar os melhores resultados.

Gramsci (1999) assevera que, o professor precisa conhecer a realidade do jovem e a sua própria realidade, assim como estar atento às contradições da sociedade, para organizar um ensino que privilegie o desenvolvimento deles. Assinala que

Por isso, pode-se dizer que, na escola, o nexo instrução-educação somente pode ser representado pelo trabalho vivo do professor, na medida em que o professor é consciente dos contrastes entre o tipo de sociedade e de cultura que ele representa e o tipo de sociedade e de cultura representado pelos estudantes (GRAMSCI, 1999, p. 44).

Além de observar o modo de vida dos estudantes, Gramsci (1999, p. 46) assinala que o professor precisa disciplinar os adolescentes com atos que os direcionem a obter hábitos de diligência, compostura e concentração psíquica. O que significa que para ele, como supramencionado no capítulo anterior, para além de um ensino desinteressado e propiciar aos jovens meios para desenvolver sua criatividade e interesse pela cultura geral, o professor precisa também orientar os adolescentes, para que aprendam ter domínio de conduta. Ainda sobre a atividade docente e a estrutura de escola, Gramsci assinala que:

Assim, escola criadora não significa escola de "inventores e descobridores"; ela indica uma fase e um método de investigação e de conhecimento, e não um "programa" predeterminado que obrigue à inovação e à originalidade a todo custo. Indica que a aprendizagem ocorre notadamente graças a um esforço espontâneo e autônomo do discente, e no qual o professor exerce apenas uma função de guia amigável, como ocorre ou deveria ocorrer na universidade. Descobrir por si mesmo uma verdade, sem sugestões e ajudas exteriores, é 
criação (mesmo que a verdade seja velha) e demonstra a posse do método; indica que, de qualquer modo, entrou-se na fase da maturidade intelectual na qual se pode descobrir verdades novas. Por isso, nesta fase, a atividade escolar fundamental se desenvolverá nos seminários, nas bibliotecas, nos laboratórios experimentais; é nela que serão recolhidas as indicações orgânicas para a orientação profissional (GRAMSCI, 1979, p. 124-125, aspas do autor).

Deste modo, é preciso a condução intencional da atividade para que a professora possa identificar as necessidades dos estudantes e seus momentos de viragem. O seminário, por ser uma forma de estudo colaborativa e coletiva, permite à professora coletar evidências do movimento de objetivação ou não dos processos de aprendizagem e desenvolvimento, seja pela execução final, ou mesmo pela forma como eles elaboravam a tarefa [as escolhas feitas, a divisão de funções entre os integrantes do grupo, o modo como organizavam o trabalho teórico e a apresentação, a maneira como se expressavam e afins].

Ainda sobre a organização geral do seminário os escolares/estudantes tinham um grupo que poderia ser fixo ou ser alterado durante o ano letivo e este grupo era composto por indivíduos que tinham determinadas funções e, assim, eram responsáveis por exercê-las segundo a demanda do grupo. Deste modo, havia o líder, o editor e o revisor textual, o roteirista da apresentação oral e o designer da apresentação do cartaz ou powerpoint, por exemplo. Contudo, todos deveriam saber sobre tudo a respeito da elaboração do seminário, caso houvesse algum problema no curso da elaboração da tarefa, e as funções também poderiam ser alteradas durante $o$ ano letivo.

Os resultados iniciais obtidos por alguns grupos não foram satisfatórios. Nem todos conseguiram sistematizar ações que operacionalizassem a execução do seminário. Porém, após as apresentações os jovens eram convidados a refletir, a fazer a autoavaliação do trabalho do grupo, assunto este que será abordado na situação vivencial do café filosófico.

Como o seminário era uma das últimas tarefas para o encerramento do bimestre, era nesse período que as redes sociais se mostravam mais que necessárias, porquanto nem sempre o tempo de aula era suficiente para atender a todos os escolares/estudantes e muitos deles se sentiam mais à vontade para fazer suas perguntas por este meio. Inicialmente as dúvidas estavam mais concentradas em se apropriar das normas para saber aplicá-las 
adequadamente, bem como na busca de orientações para se aprofundar no estudo de determinados conceitos que faziam parte da estrutura de cada tema.

Figura 6. Modelo de mensagem com as regras do seminário para ser enviada via WhatsApp

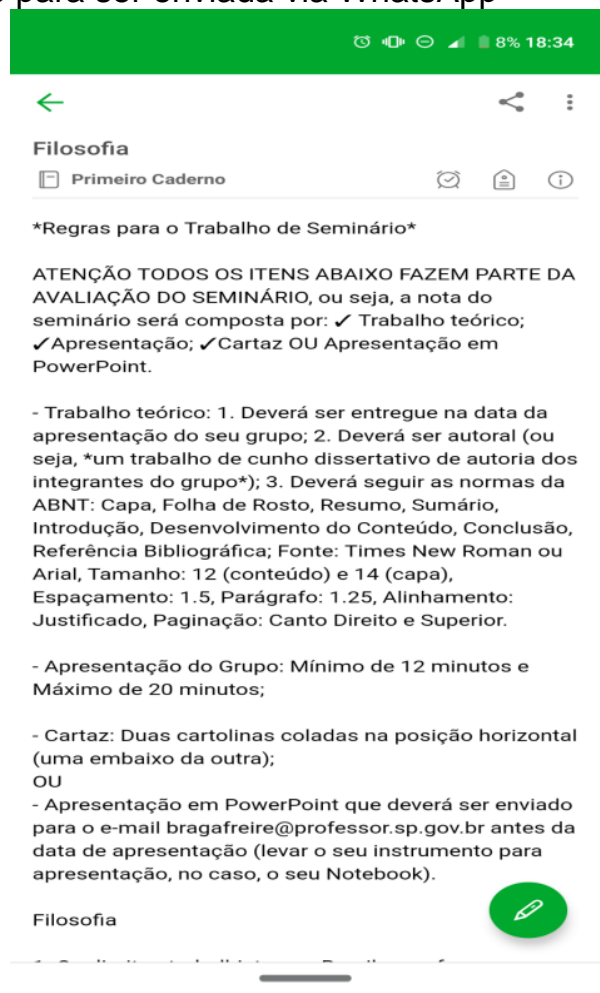

Modelo de mensagem com as regras para a elaboração de Seminário da $1^{\underline{a}}$ série do Ensino Médio que era enviada aos representantes para que estes replicassem via redes sociais. São as mesmas regras supramencionadas para a normatização desta tarefa.

Acerca das redes sociais, esta professora pegou com os escolares/estudantes que eram representantes de turma seus números de telefone e criou um grupo no WhatsApp, a fim de unificar a atividade de ensino mediada por tecnologia. Desta feita, a professora sistematizou por escrito as normas do seminário, para que os representantes de turma as (re)transmitissem aos seus pares, por meio dos grupos existentes de cada turma. Este meio de comunicação serviu também para enviar as regras das demais tarefas, avaliações e materiais de estudo extra.

Era após as aulas que a professora enviava para esse grupo, formado pelos representantes de cada turma, a síntese da aula explicitando seus principais conceitos e as normas para a elaboração das tarefas. Os representantes ficavam incumbidos de replicar as informações aos seus pares e a professora aguardava para sanar as possíveis dúvidas fora de seu horário de trabalho usual. Aguardar as mensagens individuais possibilitava que um maior 
número de jovens entrasse em contato com a professora, porque a coletividade sempre pesa quando um adolescente faz uma pergunta, independentemente do tipo de questionamento.

A coletividade, como supramencionado, é o que faz com que o adolescente assuma determinados posicionamentos e condutas, assim, neste período ele sempre estará apto a mostrar sua melhor versão e propenso a esconder suas dúvidas, receios e erros. Com a comunicação íntima-pessoal como atividade principal, o jovem tende a buscar na relação com o coletivo ao qual pertence uma forma de validação de suas ideias, atos, interesses e desejos. Destarte, é apenas quando passa a sentir segurança afetiva nesta coletividade que $o$ adolescente passa também a se expor mais (FREIRE, 2016).

No que diz respeito à apropriação das normas e regras do seminário, isso não se deu de forma imediata, mas foi mediada nas interações constituídas no decurso do ano letivo. Sobre a forma de distribuição dos temas, eles são basicamente os mesmos que estão postos no anexo do plano de ensino e de aulas, com algumas alterações dependendo do interesse, desejo e volição dos escolares/estudantes.

No primeiro bimestre, optou-se por sorteá-los entre os grupos das turmas e ter uma apresentação formal. No segundo bimestre, cada grupo teria um tema de acordo com a decisão coletiva, que foi dada por meio de um debate de defesa do porquê cada grupo deveria ficar com o tema " $x$ ", " $y$ " ou " $z$ ". No terceiro bimestre, a escolha dos temas ocorreu por meio de deliberação consensual entre as partes, sem a necessidade de discussão em um debate. E, por fim, no quarto bimestre, os temas foram elencados no processo das aulas ministradas pela professora, o que significou que se em uma dada aula um grupo se inclinasse a querer o tema poderia escolhê-lo, todavia, também não haveria problema em trocá-lo, desde que a troca fosse consensual na turma.

Há ainda que se considerar que o processo de elaboração dos trabalhos, tarefas e afins era acompanhada de forma próxima, mas que se evitava intervenções invasivas, tais como correções de percurso na forma como eles se expressavam, seja na escrita ou verbalmente, a fim de que apenas após sua elaboração e apresentação se indicasse e/ou fizesse o escolar/estudante refletir o porquê de seu erro ou acerto; orientando-o na reelaboração de sua produção e criando uma relação diferente com a ideia de erro e acerto, posto que ambos 
podem ser positivos no processo de desenvolvimento das funções psicológicas superiores, ao contrário do que prezam as pedagogias de natureza tecnicista, em que o "erro" é atacado como indício de uma celeuma perturbadora à harmonia que em tese o sistema deveria ter.

Figura 7. Escolares/estudantes produzindo painéis coletivamente

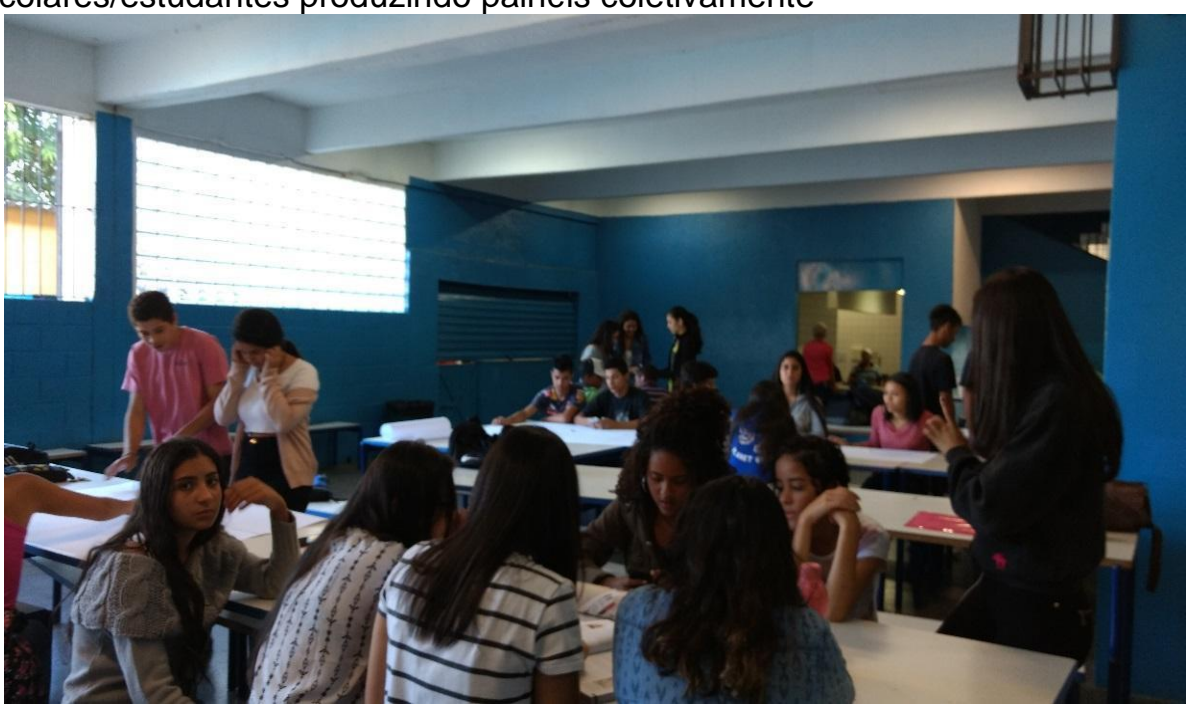

Escolares/estudantes produzindo painel para o primeiro seminário do ano letivo no pátio da unidade escolar, mecanismo utilizado para acompanhar parte do processo de elaboração da tarefa

A intenção era de que os escolares/estudantes participassem ativamente da elaboração e da produção do seminário, de modo que compreendessem como apresentar a tarefa da forma mais adequada possível, dentro das normas e regras apontadas pela professora no decurso das aulas. É válido salientar que o caos criativo dos adolescentes pode ser direcionado, sem violência e que seguir as normas e regras da forma mais adequada possível, é também parte do desenvolvimento, porquanto é engendrado neste movimento o domínio de conduta por meio do desenvolvimento do pensamento por conceitos, o que mostra que desenvolvimentos concomitantes se integram quando há intencionalidade (VIGOTSKI, 2006).

É preciso também notar que a professora também tinha determinados objetivos e intencionalidades no que concerne à expectativa do produto do seminário, e que era preciso orientar os escolares/estudantes como realizá-lo a partir e dentro de certas premissas e perspectivas que norteavam o processo de avaliação, considerando evidentemente as especificidades do contexto escolar e as contingências e problemas que poderiam acontecer no processo. 
E neste processo não só os aspectos cognitivos eram alterados, pois a confiança entre escolares/estudantes e a professora foi crescente, assim como a confiança entre os jovens e seus pares. Ademais, apenas no decorrer do ano letivo é que se percebe 0 movimento de transformação nos escolares/estudantes, pois há no início desse período a produção de determinados materiais pelos escolares/estudantes e em seu transcurso há uma mudança qualitativa, tanto no que concerne à escrita, quanto às suas participações orais, na sala de aula. Isso não significa que as produções iniciais fossem consideradas de ordem inferior, mas apenas foram as possíveis para aquele momento da aprendizagem, como dito anteriormente na seção do esquema conceitual.

Figura 8. Escolares/estudantes apresentando seminário com painel

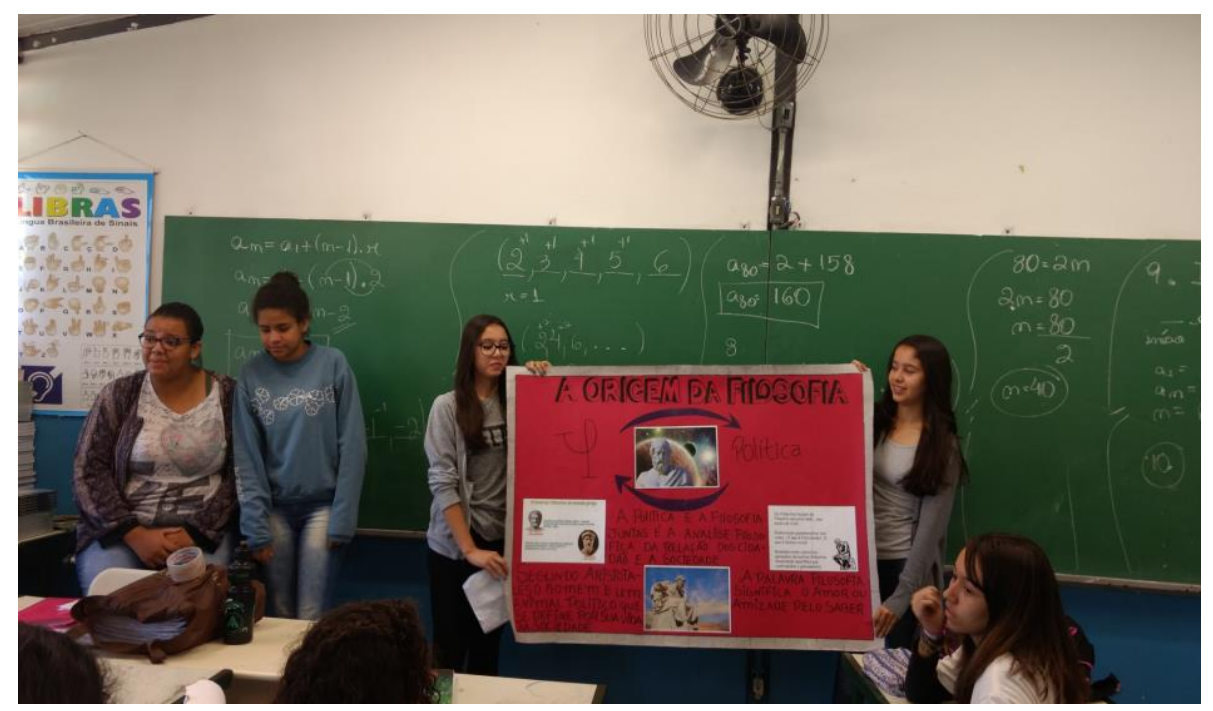

Primeira apresentação de seminário de um grupo (Registro fotográfico da Professora, 28/03/2017)

No decorrer do tempo os escolares/estudantes passaram a se organizar de formas diferentes, para a apresentação de seus trabalhos e, às vezes, agregaram elementos que surpreenderam positivamente a professora. Através da coletividade, eles também passaram a transformar suas produções, pois a própria forma de os escolares/estudantes se expressarem, serve como meio para que os demais se apropriem de formas ainda mais elaboradas para manifestar seu aprendizado. Isso ocorre porque a comunicação íntima-pessoal é de grande apelo neste período da vida, como predito. 
Figura 9. Escolares/estudantes apresentando seminário por meio do power point

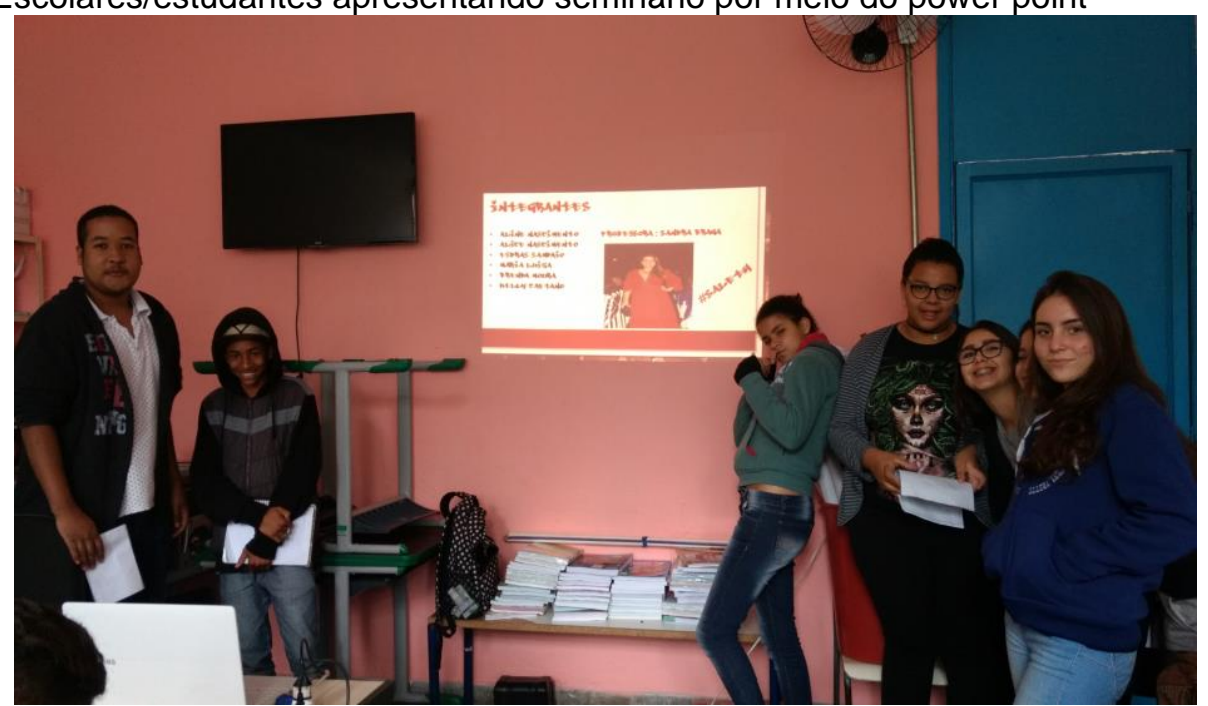

Segunda apresentação de seminário (Registro fotográfico da Professora, 20/06/2017)

Observa-se a alteração na forma de apresentação e a incorporação de novos integrantes no grupo

Nesse contexto, a atividade pedagógica e a atividade filosófica são de suma importância para o desenvolvimento do humano no homem no decurso da práxis pedagógica, pois é na coletividade de estudos que é possível ao escolar/estudante, parafraseando a teoria marxiana, transformar a si mesmo, aos outros e o seu meio, valendo-se, neste caso, do conhecimento teóricofilosófico apropriado.

No segundo bimestre, por exemplo, os escolares/estudantes formaram um grupo em que o líder deveria se juntar aos demais líderes para decidirem por meio de um debate quem ficaria com cada tema. Neste debate, foi decidido também que seria mais interessante para esta tarefa, incluir, além da apresentação oral, que passou a ser de no mínimo 5 minutos e máximo de 10 minutos, uma apresentação que deveria conter um vídeo ou um painel artístico de autoria própria para expressar e/ou representar o que seria cada tema na realidade concreta. 
Figura 10. Escolares/estudantes debatendo antes do seminário

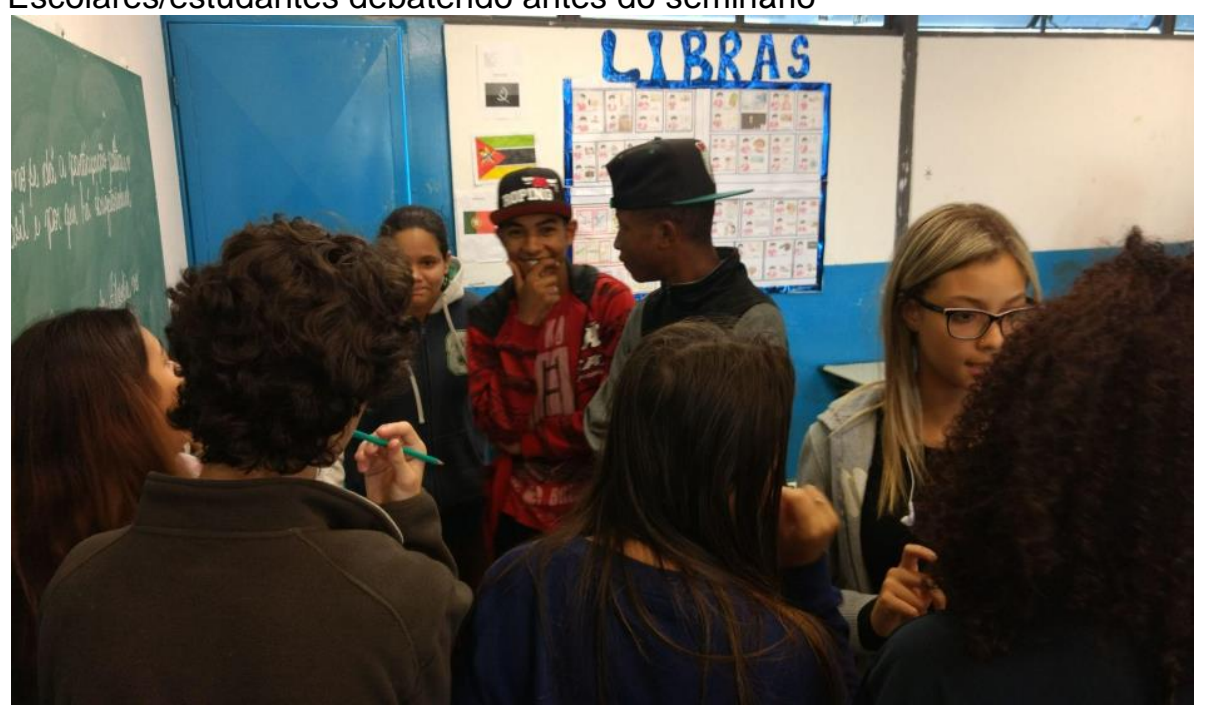

Jovens Líderes de Grupo no debate para escolha do tema para o Seminário do 2º Bimestre (Registro da Professora, 24/05/2017)

Como fora dito anteriormente, cada regra do seminário e a forma de escolha dos temas tem o seu porquê de existir, uma intencionalidade. A intenção era promover a atividade de estudo formativa, como predito, em que o conhecimento teórico, na função de mediador, pudesse possibilitar o movimento dialético de constituição de si pela apreensão do concreto na mediação do abstrato, bem como promover a passagem do senso comum ao concreto pensado, a fim de objetivar um vínculo consciente do escolar/estudante para com uma atividade que fosse deveras formativa.

Este formar aplicado em sentido mais amplo, significa que os escolares/estudantes se apropriaram de alguns instrumentos, símbolos e signos, por meio desta situação vivencial integrada às outras, e com isso foram possibilitadas condições para a formação e/ou desenvolvimento de novos afetos, interesses, volições e, por que não, vivências e funções psicológicas.

Ou seja, eles estiveram em atividade, uma atividade formativa, coletiva e integrada de estudo, isso porque na medida em que eles participaram e sentiram-se participantes do processo, porque "elaboraram" através de suas próprias reflexões estes afetos, interesses, volições e vivências, tiveram a possibilidade de compreender os nexos causais do conhecimento teóricofilosófico em movimento.

E como supracitado, estas atividades integradas para promover a formação e o desenvolvimento não precisam necessariamente estar vinculadas 
à produção de uma tarefa tradicional ou clássica, a rigor. Para alavancar o desenvolvimento dos escolares/estudantes, o professor também pode lançar mão de ações e operações desinteressadas. A seguir esta professora irá apresentar a situação vivencial chamada café filosófico.

\subsubsection{Situação Vivencial 2: O Café Filosófico}

Havia um momento que extrapolava as situações vivenciais já mencionadas no que concerne à articulação direta entre a apropriação do conhecimento teórico-filosófico e a integração entre esta apropriação e 0 desenvolvimento da afetividade, dos interesses e das volições. Esse momento foi denominado de café filosófico.

Neste momento havia a partilha de uma mesa de café da manhã, em que professora e escolares/estudantes se sentavam para debater, coletivamente, o que fora apreendido ou não no decurso das aulas. Esta reunião ocorria ao fim do bimestre ou ao fim de cada mês, dependendo da necessidade da turma.

O café filosófico constituía uma situação vivencial complexa, em que havia uma reunião/confraternização entre os escolares/estudantes da turma e a professora. Era ao mesmo tempo a expressão da síntese bimestral das tarefas feitas e dos conceitos apropriados, porquanto era o momento em que havia a organização coletiva para uma conversa acerca da produção realizada no transcurso de um bimestre e era um momento para mobilização da afetividade, dos interesses e das volições, em que o café poderia ser tomado, ipsis litteris, como uma reunião/confraternização matinal, constituída por alimentos para suprir a parte biológica e psicológica de todos, numa integração do cognitivo ao afetivo e ao volitivo, buscando expressar na práxis aquilo que fora proposto por Vigotski (2006).

Diz-se que essa era uma situação complexa, porque além do café filosófico ser a articulação de uma autoavaliação bimestral (ou mensal), dependendo da análise da apropriação ou não do conhecimento teóricofilosófico, havia também a partilha de assuntos plurais e pessoais. Assim, o escolar/estudante poderia se sentir livre para relatar à professora sua 
experiência acadêmica no decurso de um período, bem como contar sobre o andamento de sua vida particular de uma forma geral.

Para que os escolares/estudantes não se sentissem constrangidos, não houve gravação em vídeo destes momentos, apenas registros fotográficos e anotações por parte desta professora, a partir dos apontamentos realizados e das interações feitas no decurso do evento.

A questão norteadora da autoavaliação ia para além do clássico o que você aprendeu? e o escolar/estudante era conduzido a refletir sobre o que considerava mobilizador para a sua aprendizagem, assim como a pensar sobre os pontos dificultadores para o seu desenvolvimento e apropriação e sobre quais estratégias ele poderia sugerir, a fim de se pudesse ajudá-lo a superar os possíveis problemas e obstáculos que encontrou durante o período em debate.

De início, não foi fácil conseguir alguma resposta, porquanto eles achavam "mais fácil" que quem os avaliasse fosse tão somente a professora, mas quando passaram a compreender o porquê desta situação vivencial, que ela poderia colaborar para a melhora da qualidade da aula e da aprendizagem de modo geral, passaram a se expressar com mais facilidade e tranquilidade, pois viram que muito do conteúdo de suas falas era incorporado em outras situações vivenciais, a posteriori, na (re)elaboração da forma como era construído o esquema conceitual ou das normas do seminário.

Destarte, a integração entre o cognitivo, o afetivo, os interesses, as volições e as vivências não é um processo imediato, mas mediado. É comum que os escolares/estudantes não se sintam completamente à vontade, em um primeiro momento, assim como alguns não conseguiram se soltar completamente até o final desta intervenção.

Todavia, é preciso assinalar que não são quaisquer mediações que podem provocar uma transformação nas funções psicológicas superiores dos estudantes. É preciso que haja organização das ações e operações para além de determinada intencionalidade que, no presente caso, é a promoção do desenvolvimento da consciência crítica, por meio da integração entre a apropriação do conhecimento teórico-filosófico aos aspectos afetivos, aos interesses, às volições e às vivências na atividade pedagógica e filosófica.

$A$ atividade nesta intervenção esteve direcionada para integrar a atividade filosófica e a atividade pedagógica, a fim de objetivar, na realidade concreta da 
sala de aula, a unidade entre significado e sentido da professora e dos estudantes, na ascensão do senso comum à consciência filosófica.

Gramsci (2000a, 2020) assinala que o professor precisa conhecer a realidade da criança e a realidade em que ela vive, para além de estar atento às contradições da sociedade. A Seduc-SP naquele momento não fornecia instrumentos, tampouco espaço para que esta coleta de dados fosse realizada de maneira pormenorizada. Inicialmente, o café filosófico foi um mecanismo de aproximação da vida e da realidade dos escolares/estudantes, bem como do real desenvolvimento deles, e pelas condições concretas vivenciadas ali, acabou extrapolando sua utilidade primeira, passando a ser um poderoso meio de integração entre a cognição, a afetividade, os interesses e as volições no contexto escolar. O café filosófico, por conseguinte, foi um poderoso combustível para girar o eixo-motriz das situações vivenciais, como será evidenciado adiante.

Além de observar o modo de vida dos estudantes, para organizar e sistematizar um ensino, que potencialize a aprendizagem e o movimento à Zona de Desenvolvimento Proximal dos estudantes, é preciso ter ciência de que

Por isso, pode-se dizer que, na escola, o nexo instrução-educação somente pode ser representado pelo trabalho vivo do professor, na medida em que o professor é consciente dos contrastes entre o tipo de sociedade e de cultura que ele representa e o tipo de sociedade e de cultura representado pelos estudantes. (GRAMSCI, 1999, p. 44).

O café filosófico, dessarte, está inserido como estratégia metodológica, para fazer a defesa do estudo desinteressado tal como asseverou Gramsci (1979, 2000a, 2020), haja vista que todos os estudantes devem ter assegurado o direito ao acesso à cultura elaborada sócio-historicamente e, não logo de primeira instância, a uma profissão. Todos os jovens deveriam ter o direito de acessar a cultura universal, porquanto "[...] retirar dos pobres o direito ao acesso à cultura universal sob o pretexto de encaminhar o jovem mais rapidamente para o mercado de trabalho é uma forma de perpetuar as contradições de uma sociedade desigual" (GRAMSCI,1999, p. 49).

Outro ponto que não pode ser deixado de lado é o de que a consciência de algo não é produto direto da atividade externa, com objetos e situações, não é reflexo, tampouco produto espontâneo. É preciso, como supramencionado, mobilizar uma intencionalidade, para que os sujeitos da atividade se sintam 
afetados, interessados, decididos a participar e para que a situação vivenciada tenha o mesmo sentido e significado compartilhados pelos sujeitos da intervenção pedagógica. Daí pode-se dizer que

[...] é o intercâmbio e a colaboração que se realiza por meio destas, o que produz no ser humano as vivências das experiências e dos fatos que aquelas produzem, e, então, em razão de outra parte da mediação, os conteúdos psicológicos já formados com anterioridade no sujeito contribuem à atribuição de sentidos que essas vivências produzem e, por meio delas, aqueles fatos e experiências, e aquele algo que as produzem conseguem converter-se em conteúdo da subjetividade e da consciência.(BEATÓN, 2017, p. 161) .

É válido assinalar que o café filosófico, neste sentido, imprime e expressa na realidade concreta da escola, a máxima marxiana de que as relações sociais constituem a essência e o motor para o desenvolvimento do ser humano enquanto gênero, produtor e produto da cultura. Esta situação vivencial, assim, representa a integração das outras duas e, concomitantemente, incorpora o modus operandi de ser o produtor e produto delas de modo dialético, pois alimenta o conteúdo e a forma de análise do plano de aula, para a execução do esquema conceitual e do seminário, bem como é resultado destes. O café filosófico, por conseguinte, alimenta o debate da autoavaliação de determinado período, alimenta biologicamente seus participantes e alimenta metodologicamente as demais situações vivenciais.

Figura 11. Execução da Intervenção Didática e Unidade das Situações Vivenciais

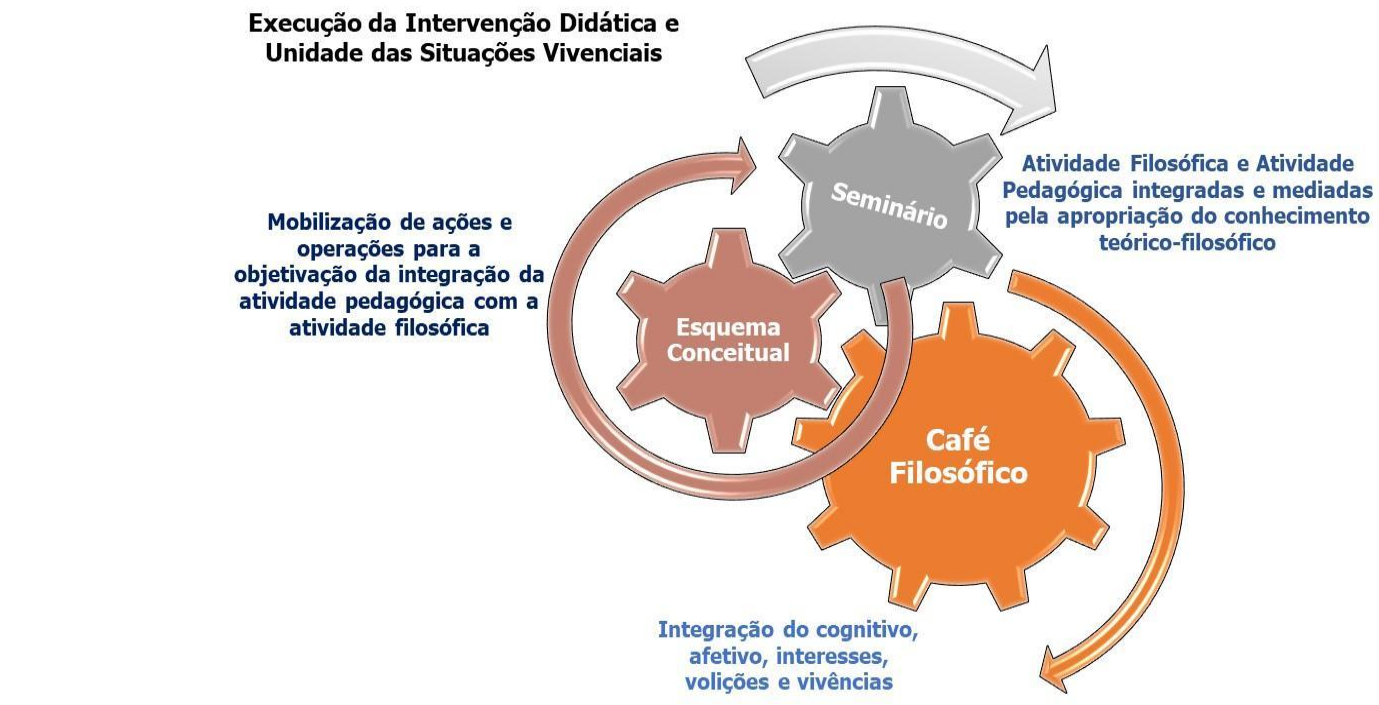

Imagem de autoria própria 
Neste sentido, o café filosófico vem para coroar a intervenção didáticopedagógica, com a integração entre o particular e o singular, posto que por meio da apropriação do conhecimento teórico-filosófico dado no esquema conceitual e das mediações feitas, a partir daquele no seminário, que produziram apropriações outras e o desenvolvimento de outros aspectos, como o pensamento por conceitos e o domínio de conduta, vinculando o cognitivo e o afetivo, ao garantir seu espaço, como representação do eixo motriz na articulação de sentidos e significados, tanto para professora, quanto para os estudantes, na promoção da unidade entre interesses, volições e vivências nesta experiência ímpar.

No particular e no singular, na vida real, na cultura, no sistema de relações sociais e nas formas de produzir sua existência e garantir sua vida na natureza, as pessoas vão constituindo seus sentimentos, emoções, necessidades e motivações; suas ideias, seus conhecimentos, o desenvolvimento e a formação dos processos cognitivos, sua consciência e sua autoconsciência, seu inconsciente, seus recursos de regulação e autorregulação, que são internos e que permitem o controle de seu próprio comportamento, de sua vontade, sua concepção de mundo: sua personalidade. (BEATÓN, 2017, p. 145146).

Assim, compreende-se que, neste processo dinâmico, dialético, caótico e contraditório, foi produzida uma relação indissociável entre cognição, afetividade, volição e vivência. Porquanto, há condições e possibilidades reais para que o jovem, de certo modo, se aproprie do conhecimento teórico-filosófico e que isso impacte o desenvolvimento do seu pensamento conceitual, este mesmo jovem está também, na integração das atividades [a pedagógica e a filosófica], pode subjetivar este conhecimento, internalizar e objetivar interesses e volições nesta situação vivencial.

O movimento no café filosófico traz à tona as subjetivações encarnadas no esquema conceitual e no seminário, tendo em vista que segundo Beatón, ao estudar a teoria vigotskiana, "todo o intrapsíquico ou intrapessoal é um produto do interpessoal e dos conteúdos da cultura implicados nele" (BEATÓN, 2017, p. 153).

Destarte, um processo de escolarização só é capaz de produzir neoformações e desenvolvimento das funções psicológicas superiores, quando 
o escolar/estudante é impactado, de tal maneira, a alterar os sentidos e o significado que atribuía à escola e aos estudos, transformando-os internamente, reproduzindo o que foi apropriado sob orientação do professor, que intencionalmente tem o conhecimento teórico enquanto mediador, mas não abdica da subjetivação dos conceitos, até mesmo porque é este movimento que torna a atividade filosófica e a pedagógica integradas tão profícuas para 0 desenvolvimento em direção às máximas possibilidades humanas.

Como supramencionado, uma escolarização que se pretende desenvolvedora perpassa um trabalho que tem como necessidade ações e operações que ultrapassam os aspectos técnicos e se direciona para engendrar condições de integração entre cognição e a afetividade, a fim de possibilitar a mobilização do sujeito para o desenvolvimento de uma consciência que perceba tanto as nuanças da subjetividade, quanto as da esfera cognoscitiva, podendo elaborar ainda novas vivências e se aproximar ainda mais da escola e dos estudos.

A escola precisa ser um lugar que inspira e transpira interesses e volições na vida objetiva dos jovens, por isso, as vivências, que uma intervenção pedagógica visa criar, precisam estar vinculadas às dos escolares/estudantes, de tal modo, a fim de impulsioná-los, tanto no desenvolvimento, quanto na atividade. Esta situação vivencial ocorria normalmente como última tarefa do bimestre, após o seminário e a prova; os escolares/estudantes eram adequadamente orientados para utilizar a comunicação íntima-pessoal positivamente na organização deste evento.

No primeiro evento do café filosófico, assim como nos demais, a professora permitiu que os escolares/estudantes se auto-organizassem para gerar a melhor maneira de distribuição de responsabilidades. Eles conseguiram encontrar os melhores dias para que o evento acontecesse durante 0 ano letivo, sempre com bastante antecedência para que ele pudesse ocorrer após o pagamento dos responsáveis, porque deste jeito poderiam comprar os alimentos, os descartáveis e afins dentro do orçamento da família, sem prejudicar ninguém e considerando sempre a coletividade.

Neste contexto eles se mostraram extremamente respeitosos e responsáveis, e em nenhuma das ocasiões foi necessária uma intervenção para a manutenção da ordem ou para qualquer finalidade. Este tipo de sistematização 
da situação vivencial perpassa pela concepção gramsciana de que "[...] a escola criadora precisa, portanto, disciplinar e, concomitantemente, expandir a personalidade em direção à autonomia, à responsabilidade e a uma consciência moral coletiva" (GRAMSCI,1999, p. 39).

Figura 12. Escolares/estudantes em Café Filosófico

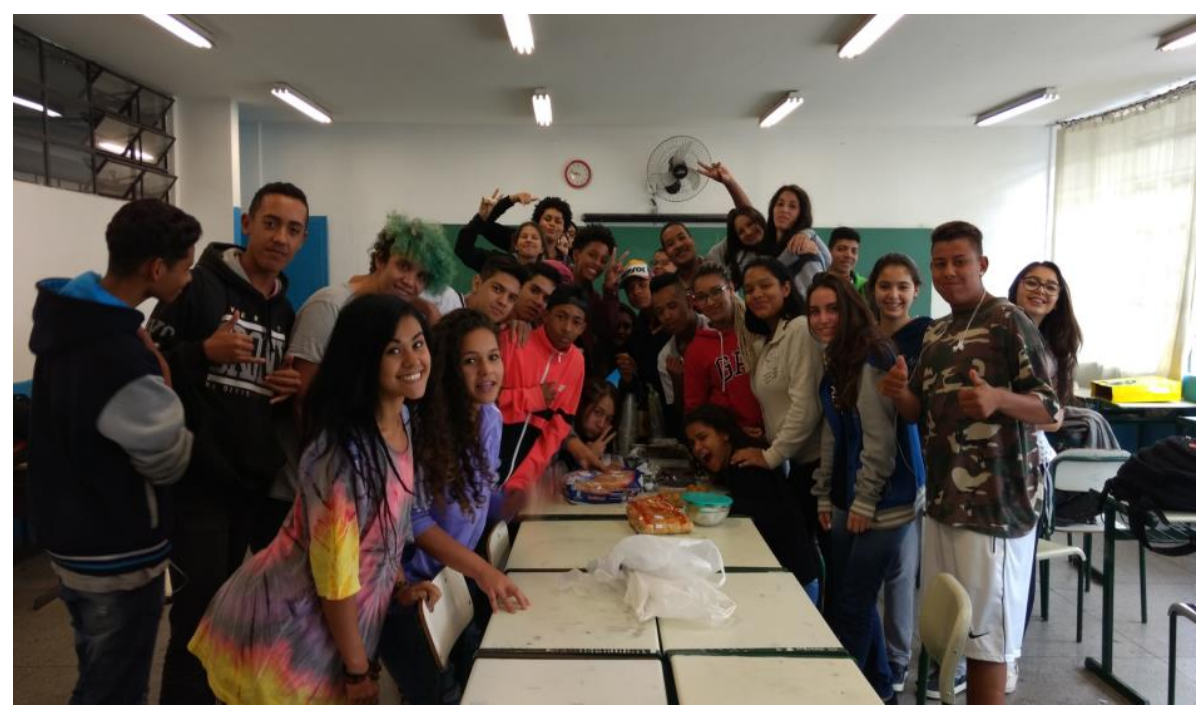

Café Filosófico (Registro da Professora, 17/05/2017)

Já que na escola em que foi feita a intervenção didático-pedagógica as salas tinham espaços físicos diferentes (o que é comum nas escolas do Estado de São Paulo), havia a busca de um espaço maior, no dia de certos eventos, para que todos ficassem confortáveis, como era feito no café filosófico. Acima, há o registro do primeiro café filosófico da turma, em que os estudantes fizeram a autogestão do evento de forma primorosa, mas, para além disso, estavam bastante curiosos para saber como seria a experiência.

$\mathrm{Na}$ autoavaliação, antes de nos entretermos com os alimentos, foi proposta a reflexão, para que eles expusessem a experiência que tiveram com o componente curricular Filosofia, dado seu marco inédito, para a maior parte do grupo. Alguns apontaram que, a princípio, acreditavam que iriam ter muita dificuldade na matéria, porque a Filosofia possuía uma "fala diferente que já pegava e do nada os levavam para várias viagens", mas que aos poucos "bem no passo da formiguinha", eles compreenderam que não é tão difícil "é só prestar atenção" (entre aspas o apontamento de alguns escolares/estudantes em 17/05/2017, extraído do caderno pessoal da professora). 
É interessante notar que, para eles, este "é só prestar atenção" trata-se de um comportamento natural e sem dificuldades, todavia, a teoria vigotskiana assevera que o domínio de conduta é também parte do desenvolvimento do sujeito e que por ser uma função psicológica superior, necessita de mediações precisas e intencionais. Mais interessante ainda é salientar a interfuncionalidade dialética neste processo, posto que o domínio de conduta para ser formado e desenvolvido precisa que o sujeito se aproprie de conhecimentos teóricos e, para que estes conhecimentos teóricos sejam apropriados, é preciso certo domínio de conduta. Essa percepção remete ao que afirma Beatón:

\footnotetext{
Por essa razão defende-se que o educador, antes de se propor a educar e organizar o ambiente ou contexto social em que se realizará o processo educativo e de ensino, deverá conhecer, o mais profundamente possível, os estudantes, as relações sociais que eles estabelecem, as atividades e a comunicação que realizam, os conteúdos culturais, conforme, deve-se supor, impactarão ou influirão em cada estudante, segundo suas características e desenvolvimentos reais e potenciais. (BEATÓN, 2017, p. 156).
}

O professor, desta feita, precisa estar atento a um dos termômetros da sala de aula, a saber, as expressões faciais dos escolares/estudantes, que dependendo do apontamento feito, da palavra dita, da conexão realizada, da pergunta feita, expressarão como se sentem com relação ao apresentado. Os adolescentes por serem intempestivos dificilmente mascaram suas feições de espanto, admiração, dúvida, incompreensão diante de algo, isso a experiência desta professora comprova nesta intervenção (para além do que já havia vivenciado), como será apresentado adiante.

E é nesta situação vivencial que outros encontros e relações foram formadas e firmadas, porque só os muros da escola não comportavam o que era vivenciado nesta intervenção didático-pedagógica. E assim, alguns encontros fora da escola aconteciam entre diferentes grupos de escolares/estudantes e a professora. Como assevera Vigotski (2006), o professor tem primordial importância na adolescência, tanto na orientação dos estudos, quanto na adequada condução de determinadas subjetivações que vão surgindo no curso das relações da escola.

Isso não significa, como aponta Gramsci, que se deve desconsiderar a preparação para o mercado de trabalho, ou o ensino tradicional, mas que a 
formação para os mais pobres não pode estar baseada apenas no tecnicismo, na formação de sujeitos adequados a uma determinada sociedade (GRAMSCI, 1999, p. 39), como também apregoa a essência da letra da lei hodierna.

O aprendizado na escola, deste modo, deveria estar voltado para a apropriação da metodologia científica, para uma "autodisciplina intelectual e a autonomia moral necessárias para uma posterior especialização, seja ela de caráter científico, [...] seja de caráter imediatamente prático produtivo [...]" (GRAMSCI, 1999, p. 39), mas também para conhecimentos despretensiosos e desinteressados de uma utilidade prática imediata, afinal de contas, nem a Filosofia tem sua utilidade natural garantida para o sistema capitalista.

A partir disso é possível assinalar que o jovem precisa ter acesso a uma escola que contribua para desenvolver o elemento da responsabilidade autônoma, assim como de uma escola que o motive a conhecer o que é o conhecimento teórico e que vise integrar as esferas cognitivas às afetivas na produção de um olhar e de uma consciência que se distancie cada vez mais da heteronomia. Esta escola também precisa mostrar que é interessante estudar fora de casa, em um ambiente coletivo e colaborativo para a troca de ideias, para promover a apropriação de conceitos e de formas de enxergá-los.

Figura 13. Escolares/estudantes em Confraternização Filosófica fora dos muros escolares

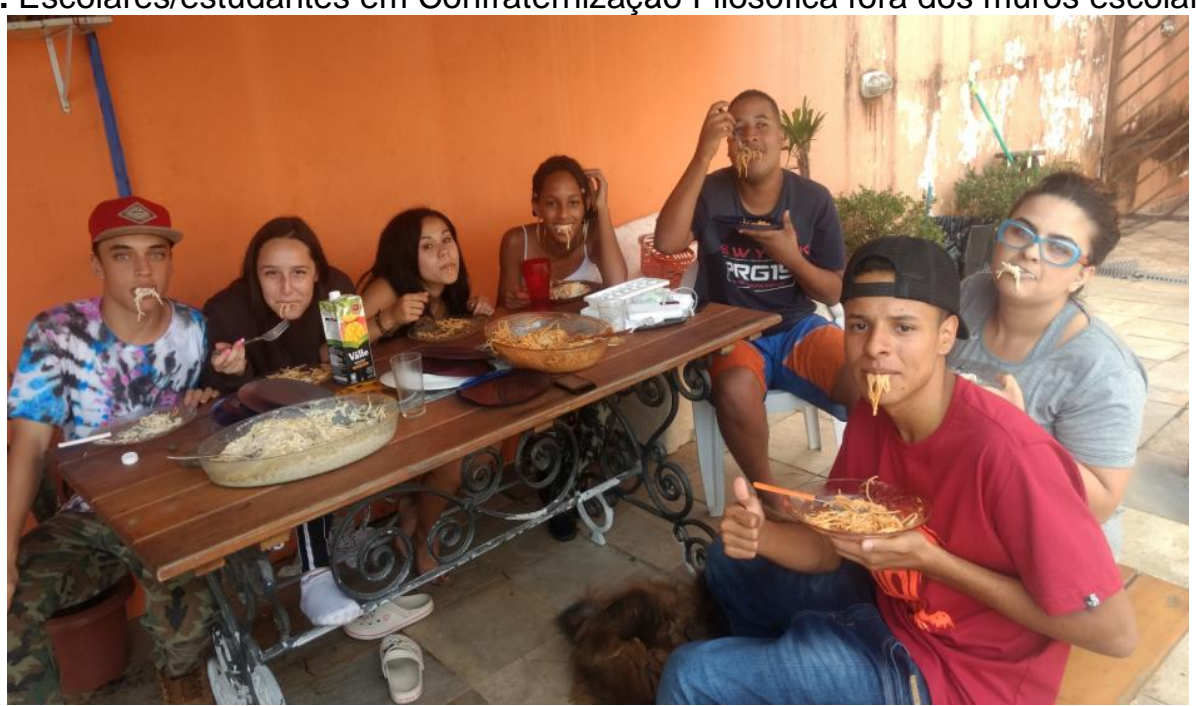

Confraternização Filosófica na casa de uma das escolares/estudantes (Registro da Professora, 14/08/2017)

Acima o registro de um encontro filosófico que aconteceu para além dos muros escolares, como produto do café filosófico, pois como um dos 
escolares/estudantes indicou "quem participa do café filosófico não quer só café, mas almoço filosófico, tudo filosófico, para uma vida de filosofante" (entre aspas o apontamento de um escolar/estudante no encontro na casa de um dos jovens em 14/08/2017, registro extraído do caderno pessoal da professora).

Este encontro possibilita inferir que as relações engendradas no espaço escolar criaram uma condição diferenciada de perceber a escola, os estudos e a professora, e que o acesso ao conhecimento pode estar na escola ou no cotidiano, numa mesa de almoço, por exemplo. A frase do escolar/estudante, por outro lado, assinala que este espaço, o da escola, não é o único responsável pela mediação do conhecimento, que ele não basta, e com o uso do gerúndio, talvez seja possível depreender que filosofar é processo, um movimento que sempre está elaborando, refletindo, constituindo e transformando.

Acerca do supracitado, a respeito da conduta intempestiva dos adolescentes e sobre a afirmação de que eles dificilmente mascaram suas feições diante de algo, em certa ocasião um dos jovens ao sentir que esta professora não estava com o comportamento de forma contumaz, extrovertido e alegre, pede para sentar-se ao lado dela para saber "o que estava pegando". Ao final da conversa, o registro fotográfico "para firmar a amizade" e expressar que ele se compadecia da tristeza da professora, ele também deu para ela uma folha de caderno em formato de coração com a hashtag "a tristeza me domina" como uma representação do "tamo juntos" (entre aspas as falas do adolescente no dia 04/10/20107, anotação extraída do caderno pessoal da professora). Abaixo a foto mencionada: 
Figura 14. Escolar/estudante com a professora

(Registro do Escolar/Estudante enviado para a professora, 04/10/2017)

É a dialética dada na integração entre as situações vivenciais com a apropriação do referencial teórico da Teoria Histórico-Cultural, da Psicologia Histórico-Cultural e da Pedagogia Histórico-Crítica e a vivência desta professora, a saber, a experiência de viver na carne o processo histórico de dissolução da Filosofia enquanto componente curricular, assim como da escolarização tida como clássica de modo geral, em que de forma explícita se institucionaliza uma escola para pobres e outra para ricos, integrada ao desenvolvimento de uma consciência crítica superior àquela de outrora, por causa dessa vivência encarnada, que se operacionalizou esta intervenção didático-pedagógica.

Sem o movimento acima e a outra integração, a da cognição com a afetividade, os interesses, as volições e as vivências, no processo de escolarização, esta professora também não teria se tornado a última cavaleira do apocalipse, que assume o lugar de não apenas denunciar, mas de se recusar, apesar do atual contexto, a ser indiferente. Como assevera Gramsci (2020)

Odeio os indiferentes, [...] "viver quer dizer tomar partido". [...] Quem vive verdadeiramente não pode ser cidadão, sem assumir um lado. Indiferença é apatia, parasitismo, velhacaria, não é vida. [...] $A$ indiferença é o peso morto da história. É a bola de chumbo dos inovadores, é a matéria inerte na qual afundam rapidamente os entusiasmos mais esplêndidos [...]. A indiferença opera com força a história. Opera passivamente, mas opera. É a fatalidade; é aquilo com que não se pode contar; é aquilo que estraga os programas, que inverte os planos mais bem construídos; é a matéria bruta que se rebela contra a inteligência e a estrangula. $O$ que acontece, o mal que recai sobre todos, o bem possível que um ato heroico (de valor 
universal) pode gerar não se deve tanto à iniciativa dos poucos que agem, mas à indiferença, ao absenteísmo de muitos. [...] Sou resistente, vivo, já sinto pulsar nas consciências viris da causa que escolhi a cidade futura que essa causa está construindo. E nela a cadeia social não pesa sobre poucos, nela cada coisa que acontece não é por acaso, por fatalidade, mas pela ação inteligente dos cidadãos. Não há nela ninguém que esteja na janela só olhando enquanto poucos se sacrificam, sangram em sacrifício; e aquele que estiver na janela, em uma emboscada, quererá usufruir do pouco bem que o trabalho de poucas pessoas tentou realizar e descontará a sua desilusão insultando o sacrificado, o sangrado, porque não conseguiu cumprir seu objetivo. Vivo, tomo partido. Por isso odeio quem não o faz, odeio os indiferentes (GRAMSCI, 2020, p. 27-28).

Fato é que há muito o que se fazer, por isso, é válido salientar que se esta professora-proletária pode assumir este posto de ódio aos indiferentes, por meio da apropriação de um referencial teórico e da vivência na carne da destruição do ensino básico, apesar das intempéries e das contradições da realidade objetiva, outros professores também podem assumir esta função. Não é uma luta fácil, tampouco rápida. Demanda por parte dos sujeitos certos interesses e volições: o da promoção da cultura sócio-historicamente elaborada e sua oferta aos mais pobres, ao compartilhá-la, como o alimento no café filosófico, sem amarras ou barreiras. 


\section{CONSIDERAÇÕES FINAIS}

A síntese que, por ora se apresenta, tem como finalidade propor 0 exercício da atividade filosófica, ao anunciar as possíveis respostas à problemática anunciada nesta pesquisa, a saber, investigar quais são as condições necessárias, para possibilitar um ensino desenvolvedor, por meio da apropriação do conhecimento teórico, no ensino de Filosofia no Ensino Médio de uma escola pública estadual, tendo em vista a integração entre as esferas cognitiva, afetiva e volitiva, feita a partir do que prescreve o Currículo do Estado de São Paulo.

Antes, é preciso asseverar que nesta parte do texto vou escrever em primeira pessoa, porquanto se esta é uma pesquisa que aborda a integração do cognitivo com o afetivo, volitivo, interesses e vivências, em que a autora ocupa um determinado lugar de fala, se assume a última cavaleira do apocalipse, por viver na carne os processos que estudou, primeiramente, é preciso afirmar aqui, nas considerações finais, que considero ter sido bastante difícil chegar ao fim deste texto.

Isso ocorreu porque a pesquisa começou de forma despretensiosa. Este era o trabalho de uma professora-pesquisadora que estava para se alçar a ser pesquisadora-professora, pensando que ainda poderia haver distinção possível entre estes sujeitos, posto que o ingresso no doutorado só ocorreria meses após o começo do ano letivo e que, por isso mesmo, poderia existir a separação entre a professora e a pesquisadora.

No entanto, a dialética estabelecida entre a professora-pesquisadora e a pesquisadora-professora acabou por criar uma unidade, porquanto a realidade não tenha parado seu movimento, para fosse possível efetuar a finalização da pesquisa e, evidentemente, essa situação antitética, acabou por afetar tanto a professora, produzindo outros eus no interior dela, quanto a própria realidade, em constante transformação de si, ao sabor das circunstâncias históricas imediatas.

Assim, mesmo sem estar efetivamente matriculada no doutorado, me propus a lançar mão de uma organização de ensino que considerasse impactar a realidade objetiva escolar, por meio de um ensino que intencionalmente se 
propusesse afetivamente desenvolvedor e era justamente essa necessidade, a de integrar o cognitivo ao afetivo, que daria unicidade à professora e ao sujeito pesquisador, haja vista que para sistematizar tal trabalho educativo ${ }^{59}$, deveria existir uma intencionalidade que seria o motor no planejamento, para articular ao conhecimento teórico os elementos motivacionais (ELKONIN, 1987), o aspecto volitivo, os interesses e as vivências, como supramencionado.

Outro motivo, para considerar difícil chegar até o fim do texto, foi o fato de que a pesquisa teve seu transcurso no decorrer da implantação da Reforma do Ensino Médio, recentemente sancionada, e resolver fazer isso sem saber muito, para além de que a Filosofia, juntamente com outros componentes curriculares, seria dissolvida nos itinerários formativos, me moveu para uma luta a partir do interior do sistema. Luta esta como quem se despede e, concomitantemente, guerreia como brava cavaleira para que haja legitimidade da Filosofia até seus últimos dias, como quem deseja que, por causa dessa luta, os adversários desistissem e ela não fosse diluída. Afinal de contas, uma professora que queria se alçar à pesquisa e que, além disso, é cavaleira, também tem o direito de sonhar.

O fato de que a pesquisa de campo ocorreu em 2017 e o texto teve sua elaboração durante todo esse período, também impactou diretamente sua finalização. E em virtude desse movimento dialético e de caos, se permitir encerrá-la foi algo tão complexo e contraditório, pois considero que este não seja o fim e que há muita luta no porvir, tendo em vista que é preciso promover a apropriação da cultura elaborada sócio-historicamente às crianças, jovens e adultos, apesar da implantação dos itinerários formativos e da oferta de uma escola empobrecida, de forma arquitetada, aos pobres.

Destarte, ao sopesar quais são as condições pedagógicas necessárias para a integração entre as esferas cognitiva, afetiva e volitiva que poderiam possibilitar a apropriação do conhecimento teórico, no ensino de Filosofia no Ensino Médio de uma escola pública estadual, situada no município de CotiaSP, há de se considerar que uma escolarização que se pretende desenvolvedora

59 Segundo Saviani (1991, p. 21), é "[...] o ato de produzir, direta e intencionalmente, em cada indivíduo singular, a humanidade que é produzida histórica e coletivamente pelo conjunto dos homens". Ao ser executado em sala de aula, pode viabilizar, por seus princípios e ações na atividade pedagógica, o desenvolvimento dos sujeitos submersos nas relações escolares. 
perpassa um trabalho educativo que tem como necessidade ações e operações que ultrapassem os aspectos técnicos.

Trabalho este que não é qualquer um, não se faz imediato, tampouco de maneira espontaneísta. Por isso, neste estudo, defende-se a tese de que a integração entre as esferas técnicas e motivacionais pode possibilitar a mobilização do sujeito, para a apropriação dos conhecimentos teóricos, promovendo o desenvolvimento de uma consciência que impacte tanto o cognoscitivo, quanto o afetivo, engendrando meios transformadores das funções psíquicas superiores em direção à genericidade humana sensível para perceber, de forma desvelada, as nuances, as disparidades e as contradições da realidade concreta.

A função da escolarização que toma como pressuposto as categorias dos referenciais teóricos da Teoria Histórico-Cultural, da Psicologia Histórico-Cultural e da Pedagogia Histórico-Crítica deve estar fundamentada na premissa de que é preciso mobilizar a apropriação da cultura acumulada sócio-historicamente de forma sistemática e intencional, sobretudo, no que concerne à linguagem, aos signos e aos símbolos produzidos em milênios, no curto período de alguns anos, como predito.

O percurso textual desta pesquisa é, assim, a expressão da apropriação da teoria supracitada por esta professora, que precisou entrar em atividade de estudo, para conseguir compreender as contradições do sistema de ensino da Secretaria da Educação do Estado de São Paulo, a fim de verificar as possibilidades de enfrentamento deste caos.

Assim, esta tese passou primeiramente por um inventário acerca da história da Filosofia, primeira fonte para forjar a armadura desta cavaleira, na compreensão da historicidade do fenômeno de idas e vindas deste componente curricular na grade escolar brasileira.

O estudo seguinte, a respeito da unidade dialética entre cognição, afetividade e volição, buscou identificar quais meios e circunstâncias poderiam conduzir a integração destas às atividades [que seriam mediadas e mediadoras] e às vivências no contexto escolar. Percurso este de suma importância, para entender o processo da apropriação da cultura socialmente elaborada, por parte dos estudantes, na particularidade da escola em que a intervenção didático 
pedagógica foi executada. Após estes estudos teóricos, esta professora se dispôs a investigar na prática as possibilidades de integração supracitadas.

Pertenciam a esta intervenção didático-pedagógica jovens que compunham uma $1^{\underline{a}}$ série do Ensino Médio da escola em que foi realizado 0 estudo. Estes estavam na fase de transição da adolescência, que passa da saída parcial da atividade anterior, à atividade de estudo, pela maturação sexual, em que a atividade principal é a comunicação íntima-pessoal, para a aproximação de uma nova atividade e de um novo período da vida.

Sabe-se que pela turbulência desta fase, que a adolescência é um estágio do desenvolvimento humano crítico, peculiaridade tal que a faz, concomitantemente, profícua para mobilizar certas transformações e extremamente instável, para empreender uma formação voltada para um certo tipo de desenvolvimento e integração específica. Todavia, ao perscrutar a realidade objetiva dos jovens, suas necessidades, é possível chegar a um plano de ensino e de aulas que se adeque a eles.

Afinal de contas, como foi apresentado no capítulo a respeito da atividade filosófica e das vivências, considerar a adolescência enquanto período permeado por conflitos, crises, contradições e afins, não é o suficiente para asseverar que seja um período intrinsecamente impossível de ensinar ou de fazer outrem aprender.

É importante lembrar que não existem problemas de aprendizagem ${ }^{60}$ neste referencial teórico, mas percursos equivocados dentro dos processos de escolarização que provocaram no sujeito uma relação negativa com os estudos e com a escola. Ainda mais em uma sociedade que propicia a fragmentação entre o sentido e o significado das funções sociais e que, por vezes, expropria e explora os sujeitos, alienando-os do seu direito constitucional, a educação escolar.

\footnotetext{
60 Patto $(1990,1997)$ e Souza (2002) apontam no que diz respeito às queixas escolares, que elas devem ser analisadas à luz dos problemas de escolarização pois as dificuldades, apresentadas pelos estudantes no que concerne às questões do não aprender têm a possibilidade de ser resolvidas, haja vista que os sujeitos têm a possibilidade de aprender, desde que o conhecimento esteja adequadamente preparado para promover a aprendizagem e o desenvolvimento psicológico, partindo do pressuposto primeiro de que existem necessidades que precisam ser atendidas.
} 
Esta cisão por vezes recai sobre o professor ou sobre os jovens, que contaminados por esta praga, não conseguem enxergar para além da precariedade do sistema educacional, de suas contradições. Por isso, assinalouse reiteradamente muitas vezes que o professor precisa irromper as brumas das imposições das políticas públicas para, no mote marxiano, fazer a revolução de dentro do próprio sistema. Contudo, este processo também não ocorre de forma imediata e espontânea.

Nesta pesquisa a intervenção didático-pedagógica foi o espaço para a práxis revolucionária, que, na integração das atividades, mostrou a formação e o desenvolvimento dos escolares em estudantes, sediada na dialética integradora entre cognitivo e afetivo, raciocínio e interesses, necessidades e volições, bem como a unidade entre a consciência e as vivências. Foi esse processo constituído e examinado nas situações vivenciais que impactou a formação e o desenvolvimento das funções psicológicas superiores, a partir da apropriação da cultura elaborada sócio-historicamente, incluída nos conteúdos escolares, permitindo aos jovens que transformassem sua relação com o conhecimento, consigo mesmos e com o coletivo, dando condições para o desenvolvimento de uma consciência crítica e para o domínio da conduta.

As situações vivenciais, por sua vez, a todo momento consideraram os conhecimentos prévios dos escolares/estudantes, sem tomá-los como ponto de partida e de chegada. Essas situações, realizadas por meio das atividades integradas às da professora [a pedagógica e a filosófica] e à mobilizada por ela [a atividade de estudo], visaram orientar os interesses, desejos e necessidades dos sujeitos às possibilidades concretas de ensinar e aprender, buscando sempre por mecanismos que propiciassem saltos qualitativos na formação e no desenvolvimento da [próxima] atividade dos jovens. É evidente que a não objetivação do ensino e os problemas de escolarização foram levados em conta, haja vista que a mobilização para a atividade, por parte dos escolares/estudantes não foi imediata, mas mediada.

Como era previsto, foi preciso conhecer o desenvolvimento real dos jovens no início da execução da intervenção didático-pedagógica e como se manifestava a atividade principal destes na escola. Estes elementos foram considerados para a elaboração do plano de ensino e de aulas, que partiu do pressuposto de que a educação escolar que integra os aspectos cognitivos, 
afetivos e volitivos às vivências tem maiores condições de superar o caos implantado pelo sistema de ensino vigente, sobretudo de uma Secretaria da Educação que na letra da lei se preocupa com uma formação integral, mas na prática nega isso aos sujeitos.

$\mathrm{Na}$ intervenção didático-pedagógica, dada nas situações vivenciais, a necessidade primeira foi, além de engendrar a integração das atividades, a saber, a atividade filosófica à atividade pedagógica, (re)conduzir os adolescentes à sua função na escola, priorizando, por conseguinte, integrar a cognição, que seria um dos meios para a apropriação dos conhecimentos teóricos-filosóficos, à afetividade, aos interesses e à volição, processo que seria orientado pela professora, assim como a organização e disponibilização dos meios que dariam corpo à necessidade de se apropriar do conhecimento teórico-filosófico.

Daí, deve-se asseverar que este movimento é caótico e dialético, em todas as circunstâncias em que ele venha a ocorrer. Logo, para dar movimento a isso, a intervenção didático pedagógica teve como pressuposto a elaboração de um plano de ensino e de aulas que considerasse as peculiaridades dos adolescentes envolvidos na pesquisa, a fim de que eles tivessem 0 desenvolvimento voltado para a (re)condução de sua função na escola, a partir da integração supramencionada. Sem essa perspectiva, incorria-se no risco de repetir o trabalho pragmático, fragmentado e descontextualizado que o Currículo já preconizava e que não pretende levar os estudantes para alcançar o máximo de suas possibilidades humanas.

Cada situação vivencial da intervenção didático-pedagógica foi pensada para promover saltos qualitativos no desenvolvimento dos escolares/estudantes, bem como para projetá-los para novos tipos de atividade. O eixo motriz da integração entre a atividade filosófica e a atividade pedagógica, por conseguinte, foi ter o conhecimento teórico-filosófico como mediador das relações coletivas e afetivas. A vivência, nesse contexto, foi categoria indispensável, juntamente com a historicidade, pois juntas possibilitam potencializar o desenvolvimento intelectual, moral e afetivo dos adolescentes no que concerne à alteração de conduta em relação à escola e aos estudos.

Por esse motivo, o conhecimento teórico-filosófico assume um papel primordial, como elemento de mediação simbólica constante no esquema conceitual, no seminário e no café filosófico. Aquele esteve sempre vinculado às 
vivências e à historicidade tanto dos jovens e da comunidade escolar, quanto do próprio contexto temporal. Diz-se constante, porque sua sistematização em um plano de ensino e de aulas esteve sempre presente, em todos os momentos das situações vivenciais que fizeram dele a estrutura basilar e o porquê da integração entre as atividades.

O conhecimento teórico-filosófico portanto, buscou (re)conduzir os motivos dos sujeitos participantes da pesquisa para permanecer e avançar na escola, bem como para estudar ou (re)elaborar as ações e operações de ensino, a fim de que estes se apropriassem de seus instrumentos, a partir da leitura, das sínteses, dos esquemas elaborados de forma autoral, do planejamento de apresentações para o seminário ou para debates, assim como na organização de uma Filosofia mais despretensiosa em sala de aula como, por exemplo, no café filosófico.

As situações vivenciais foram organizadas, do modo como foram apresentadas, para que os escolares/estudantes pudessem, em seu tempo, dominar a estrutura de sua atividade, conseguissem aprender a ter segurança nos modos como se expressavam (mais ou menos elaborados), compreendessem cada tarefa de estudo, entendessem como articular ações, a fim de que o estudo fosse coletivo e/ou individual e, em suma, para que eles percebessem que momentos desinteressados também propiciavam aprendizados. Assim, as situações vivenciais buscaram possibilitar aos escolares/estudantes que eles passassem a dominar, pouco a pouco, os procedimentos de generalização, saindo da pseudoconcreticidade, no processo de ascensão do concreto-real para adentrar o concreto-pensado.

Como predito, as situações vivenciais foram elaboradas a fim de que os jovens (re)construíssem os sentidos atribuídos à escola e ao estudar, para que seus interesses, desejos e necessidades estivessem voltados à libertação e à liberação de pré-conceitos. Para que, como assevera Freire (1993), o Paulo Freire, os sujeitos estudem para enxergar o mundo com seus próprios olhos, para se tornarem conscientes e donos de suas volições, interesses e afetos.

Nesse sentido, o movimento das situações vivenciais só foi possível porque elas foram pensadas previamente para propiciar a integração entre as atividades e a cognição, a afetividade, a volição e as vivências. Como Marx (1985) indica no antológico trecho em que distingue a abelha do arquiteto, o que 
nos distingue dos animais é poder planejar ${ }^{61}$. Aqui a intencionalidade é planejamento e plano, meio e método. Isso significa que as atividades intencionalmente sistematizadas para objetivar o desenvolvimento, a unicidade das ações e as operações para mobilizar as funções psicológicas superiores, puderam desencadear neoformações e relações interfuncionais nas situações vivenciais, que extrapolaram a atividade de estudo formativa e coletiva tradicional.

Esta atividade de estudo, formativa e coletiva, extrapolada marcou a pesquisa, no que concerne asseverar que apenas a (re)organização do trabalho educativo, a partir da integração entre as atividades orientadas pela professora, impactou a realidade, porquanto, quando os estudantes também se apropriam desta operação sistematizada e intencional, a reproduziram sistematizando ações de estudo coletivas por si mesmos, evidenciando que as atividades prática, social e coletiva contribuem para o desenvolvimento das funções psicológicas superiores, por meio de um comportamento intencionalmente voltado para isso. A evidência dessas alterações se encontra perceptível na forma de escolha de como elaborar o esquema conceitual, ou na autonomia observada para elaborá-lo sem ajuda de outrem, na maneira como passaram a escolher deliberadamente os temas dos seminários e as articulações para sua apresentação, na organização do café filosófico e, para além dele, os encontros que aconteceram fora da escola.

Assim, a reestruturação da atividade por parte dos jovens, em cada situação vivencial, indica que as forças cognitivas e as esferas motivacionais são processos que se intersectam mutuamente de forma dialética, impactando a relação deles com os estudos, com a escola e com os colegas escolares/estudantes, como supramencionado.

É válido salientar que, mesmo que as transformações sejam parciais, haja vista que operam na dinâmica da não objetivação e objetivação do ensino e da aprendizagem, estas ainda são revolucionárias. Isso é observável também no

${ }^{61}$ Conforme Marx (1985, p. 149-150), "[...] uma aranha executa operações semelhantes às do tecelão, e a abelha envergonha mais de um arquiteto humano com a construção dos favos de suas colmeias. Mas o que o distingue, de antemão, o pior arquiteto da melhor abelha é que ele construiu o favo em sua cabeça, antes de construí-lo na cera. No fim do processo de trabalho obtém-se um resultado que já no início deste já existiu na imaginação do trabalhador e, portanto, idealmente". 
desenvolvimento - que ora é explícito, ora implícito -, parte da dialética da atividade prática, pois, da mesma forma que a transformação da realidade interna e externa dos sujeitos singulares, ora é evidenciada, ora não o é, e que essas mudanças transitem, normalmente, em meio ao caos, à crise e às contradições. Ademais, a teoria vigotskiana assevera que momentos como esses são importantes, para uma transformação qualitativa dos sujeitos.

Por conseguinte, não é possível a esta professora, na experiência encarnada em vivência, não se assumir a última cavaleira do apocalipse. $O$ sofrimento dos que não aprendem, apesar da universalização da escola, e, no decurso do tempo, a implantação de políticas públicas que são na letra da lei contraditórias, é o que trouxe o ódio aos indiferentes. Para além disso, o compromisso que a Filosofia traz, de não permitir que os sujeitos permaneçam no pré-conceito e de aproveitar um dos períodos mais importantes para alavancar o desenvolvimento, só poderia, dentro da luta desta cavaleiraprofessora, fazer-se interessante, dialético e, sobretudo, cognitivo, mas sem perder a ternura.

Talvez ainda seja preciso clamar por mais soldados nesta batalha, porquanto não é só a luta em sobrelevar as manifestações do fracasso escolar que se faz urgente. Trata-se de, apesar das condições dadas pela Reforma do Ensino Médio, superar os problemas de escolarização que já existiam, os da particularidade de cada comunidade escolar e os que serão provocados por causa de uma estrutura escolar pobre, ofertada aos pobres, por ocasião dos itinerários formativos.

Vão afirmar mais uma vez, como denunciou Freire (2016), esta Freire, a Sandra Braga Freire, que as oportunidades foram dadas, mas que os sujeitos não conseguiram por falta de mérito. A luta é ainda mais tenebrosa no atual cenário pandêmico, em que a epidemia ocasionada pela Covid-19 desacortinou o que outrora acontecia de forma velada. Apesar de não ser o objetivo central desta tese, é preciso apontar que os fenômenos escolares, ocasionados pela execução da Reforma do Ensino Médio, justamente neste momento de pandemia, precisam ser estudados de forma pormenorizada, daí advém a necessidade de continuidade na luta e para que este esforço não desvaneça, novos cavaleiros precisam surgir. 
Se para esta professora-cavaleira e proletária foi possível ler Vigotski, Marx e tantos outros pensadores, é preciso chamar meus companheiros para este estudo. Afinal de contas, o meu estudo também não se encerra aqui, como este texto que termina provisoriamente, apenas enquanto reflexo do prazo institucional, mas não na práxis. Digo isso, porque quando comecei em sala de aula, poucos anos depois, pude comemorar o retorno legalizado da Filosofia aos bancos escolares. Agora vejo sua partida, enquanto a última cavaleira do apocalipse e este não pode ser o fim. Não pode... 


\section{REFERÊNCIAS}

ALVES, Dalton J. A filosofia no ensino médio: ambiguidades e contradições na LDB. Campinas, SP: Autores Associados, 2002. 153 p.

ARENDT, Hannah. A crise da educação. In: Entre o passado e o futuro.

Trad. Mauro W. Barbosa. São Paulo: Perspectiva, 2005. p. 221-247.

ARISTÓTELES. Metafísica. Trad. Marcelo Perine. Coment. Giovanni Reale. São Paulo: Loyola, 2002. v. II. 185 p.

BEATÓN, G. A. Vivência, atribuição de sentido e subjetivação da atividade, a comunicação e relações sociais. In. Maria Eliza Mattosinho Bernardes, Guillermo Arias Beatón, organizadores. Trabalho, educação e lazer: contribuições do enfoque histórico-cultural para o desenvolvimento humano. São Paulo: Escola de Artes, Ciências e Humanidades, 2017, 217 p.

BERNARDES, M. E. M. Mediações simbólicas na atividade pedagógica: contribuições do enfoque histórico-cultural para o ensino e aprendizagem. 2006. 330 f. Tese (Doutorado em Educação) - Faculdade de Educação, Universidade de São Paulo, São Paulo, 2006.

BERNARDES, M. E. M. Ensino e aprendizagem como unidade dialética na atividade pedagógica. Psicologia Escolar e Educacional, São Paulo, v. 13, n. 2, p. 235-242, jul./dez. 2009.

BERNARDES, M. E. M. O pensamento na atividade prática: implicações no processo pedagógico. Psicologia em estudo. Maringá, v. 16, n. 4, p. 521-530, dez. 2011.

BERNARDES, M. E. M. Mediações simbólicas na atividade pedagógica: contribuições do enfoque histórico-cultural para o ensino e aprendizagem. Curitiba, PR: CRV, 2012. 231 p.

BERNARDES, M. E. M; MOURA, M. O. Mediações simbólicas na atividade pedagógica. Educação e Pesquisa, São Paulo, v. 35, n. 3, p. 463-478, set./dez. 2009.

BRASIL. Constituição da República Federativa do Brasil de 1988. Brasília, DF: Presidência da República, [2016]. Disponível em: < http://www.planalto.gov.br/ccivil_03/constituicao/constituicao.htm>. Acesso em: 10 jan. 2021.

BRASIL. PL 1258/1988 de 28 de novembro de 1988. Transformado na Lei Ordinária 9394/1996. Disponível em <

https://www.camara.leg.br/proposicoesWeb/fichadetramitacao?idProposicao=18975 > Acesso em 04 out. de 2021.

BRASIL. CEB. Parecer CEB n. 15: diretrizes curriculares nacionais para o ensino médio. Brasília, DF: MEC/CNE, 1998.

BRASIL. CEE. Deliberação CEE 10/1997 de 30 de julho de 1997. Disponível em: < chrome-

extension://efaidnbmnnnibpcajpcglclefindmkaj/viewer.html?pdfurl=http\%3A\%2F\%2Fw ww.crmariocovas.sp.gov.br\%2FDownloads\%2Fccs\%2FDeliberacao_CEE_1097-

Regimento_Escolar.pdf\&clen=130856\&chunk=true >. Acesso em 04 out. de 2021. 
BRASIL. SEF. Parâmetros curriculares nacionais: apresentação aos temas transversais, ética $-1^{\circ}$ e $2^{\circ}$ ciclos. Brasília, DF: MEC/SEF, 1997a.

BRASIL. SEF. Parâmetros curriculares nacionais: introdução aos $\mathrm{PCN}-1^{\circ}$ e $2^{\circ}$ ciclos. Brasília, DF: MEC/SEF, 1997b.

BRASIL. SEF. Parâmetros curriculares nacionais: apresentação aos temas transversais, ética - 3ํㅡ e 4ํㅡㄴ.clos. Brasília, DF: MEC/SEF, 1998a.

BRASIL. SEF. Parâmetros curriculares nacionais: introdução aos $P C N-3^{\circ}$ e $4^{\circ}$ ciclos. Brasília, DF: MEC/SEF, 1998b.

BRASIL. SEMTEC. Parâmetros curriculares nacionais para o ensino médio: Parte I - Bases Legais. Brasília, DF: MEC/SEMTEC, 1999a.

BRASIL. SEMTEC. Parâmetros curriculares nacionais para o ensino médio: Parte IV - Ciências Humanas e suas Tecnologias. Brasília, DF: MEC/SEMTEC, 1999b.

BRASIL. MEC. LDB - Lei n. 4.024, de 20 de dezembro de 1961. Fixa Diretrizes e Bases da Educação Nacional e dá outras providências. DF: MEC, 1961. Disponível em:

<http://www.histedbr.fe.unicamp.br/navegando/fontes_escritas/6_Nacional_Desenvolvi mento/ldb\%20lei\%20no\%204.024,\%20de\%2020\%20de\%20dezembro\%20de\%201961 .htm>. Acesso em: 4 jan. 2019.

BRASIL. MEC. LDB - Lei n. 5.692/1971, de 11 de agosto de 1971. Fixa Diretrizes e Bases para o ensino de $1^{\circ}$ e $2^{\circ}$ graus e dá outras providências. DF: MEC, 1971. Disponível em: <http://www.planalto.gov.br/ccivil_03/Leis/L5692.htm>. Acesso em: 4 jan. 2019.

BRASIL. MEC. LDB - Lei n. 7044/82 de 18 de outubro de 1982. Altera dispositivos da Lei $n^{\circ}$ 5.692, de 11 de agosto de 1971, referentes à profissionalização do ensino de 2o grau. DF: MEC, 1982. Disponível em:

<http://www.planalto.gov.br/ccivil_03/Leis/L7044.htm>. Acesso em: 12 jan. 2019.

BRASIL. MEC. LDB - Lei n. 9394/1996, de 20 de dezembro de 1996. Estabelece as diretrizes e bases da Educação Nacional. Brasília, DF: MEC, 1996. Disponível em: <http://www.planalto.gov.br/ccivil_03/leis/19394.htm>. Acesso em: 25 set. 2019.

BRASIL. MEC. Lei n. 11.684, de 2 de junho de 2008. Altera o art. 36 da Lei 9.394, de 20 de dezembro de 1996, que estabelece as diretrizes e bases da educação nacional, para incluir a Filosofia e a Sociologia como disciplinas obrigatórias nos currículos do ensino médio. Disponível em: <http://www.planalto.gov.br/ccivil_03/_Ato20072010/2008/Lei/L11684.htm>. Acesso em: 4 jan. 2019.

BRASIL. MEC. Lei n.13.005, de 25 de junho de 2014. Aprova o Plano Nacional de Educação - PNE e dá outras providências. Diário Oficial da União, Brasília, DF., 26 jun 2014. Disponível em: https://www.planalto.gov.br/ccivil_03/_ato2011-

2014/2014/lei/l13005.htm. Acesso em: 01/05/2019.

BRASIL. MEC, SEB. Ciências humanas e suas tecnologias: Filosofia, Geografia, História e Sociologia. In. Orientações curriculares para o ensino médio. Volume 3. Brasília: Ministério da Educação, Secretaria de Educação Básica, 2006. 133 p.

Disponível em: < chrome- 
extension://efaidnbmnnnibpcajpcglclefindmkaj/viewer.html?pdfurl=http\%3A\%2F\%2Fpo rtal.mec.gov.br\%2Fseb\%2Farquivos\%2Fpdf\%2Fbook_volume_03_internet.pdf\&clen=6 28926\&chunk=true >. Acesso em: 04 de out. de 2021.

BRASIL. Medida provisória n. 746, de 22 de setembro de 2016. Texto para impressão Institui a Política de Fomento à Implementação de Escolas de Ensino Médio em Tempo Integral, altera a Lei $n \circ 9$ 9.394, de 20 de dezembro de 1996, que estabelece as diretrizes e bases da educação nacional, e a Lei $n \circ 11.494$ de 20 de junho 2007, que regulamenta o Fundo de Manutenção e Desenvolvimento da Educação Básica e de Valorização dos Profissionais da Educação, e dá outras providências. Diário Oficial da União, Brasília, DF., 22 set 2016. Disponível em:

http://www.planalto.gov.br/ccivil_03/_Ato2015-2018/2016/Mpv/mpv746.htm. Acesso em: 01/05/2019

BRASIL. Lei n. 13.415, de 16 de fevereiro de 2017. Altera as Leis $\mathrm{n} \cong 9.394$, de 20 de dezembro de 1996, que estabelece as diretrizes e bases da educação nacional, e 11.494, de 20 de junho 2007, que regulamenta o Fundo de Manutenção e Desenvolvimento da Educação Básica e de Valorização dos Profissionais da Educação, a Consolidação das Leis do Trabalho - CLT, aprovada pelo Decreto-Lei no 5.452, de $1^{\circ}$ de maio de 1943, e o Decreto-Lei ํㅡ 236, de 28 de fevereiro de 1967; revoga a Lei $n^{0}$ 11.161, de 5 de agosto de 2005; e institui a Política de Fomento à Implementação de Escolas de Ensino Médio em Tempo Integral. Diário Oficial da União, Brasília, DF., 16 fev 2017. Disponível em:

http://www.planalto.gov.br/ccivil_03/_ato2015-2018/2017/lei/l13415.htm. Acesso em: 01/05/2019.

DAVIDOV, V.; MÁRKOVA, A. El desarrollo del pensamiento en la edad escolar. In: ; SHUARE, M. (Org.). La psicologia evolutiva y pedagógica en la URSS (antologia). Moscú: Editorial Progreso, 1987a. p. 173-193.

DAVIDOV, V.; MÁRKOVA, A. La concepcion de la actividad de estudio de los escolares. In: DAVIDOV, V.; SHUARE, M. La psicología evolutiva y pedagógica en la URSS: antología. Moscú: Editorial Progreso, 1987b. p. 316- 336.

DELARI JR, A. Sentidos do "drama" na perspectiva de Vigotski: um diálogo no limiar entre arte e psicologia. Psicologia em Estudo. Maringá, v. 16, n. 2, p. 181-197; abr./jun. 2011.

DELARI JR, A. Sobre o princípio da unidade afetiva e intelectual da consciência na visão de Vigotski Paraná: Umuarama: "Estação MIR" arquivos digitais, 2020, 12 p. Disponível em <chrome-

extension://efaidnbmnnnibpcajpcglclefindmkaj/viewer.html?pdfurl=https\%3A\%2F\%2Fvi gotski.org\%2FDelari_2020_und-aft-int.pdf\&clen=238710\&chunk=true>. Acesso em: 3 out. 2021.

0

DELARI JR, A. Excertos de L. S. Vigotski sobre o tema dos "motivos". Paraná: Umuarama: "Estação MIR" arquivos digitais, 2021, 11 p. Disponível em <chromeextension://efaidnbmnnnibpcajpcglclefindmkaj/viewer.html?pdfurl=https $\% 3 \mathrm{~A} \% 2 \mathrm{~F} \% 2 \mathrm{Fvi}$ gotski.org\%2FDelari_2021_exc-Isv-mot.pdf\&clen=159381\&chunk=true>. Acesso em: 3 out. 2021.

DUARTE, N. A individualidade para-si: contribuição a uma teoria histórico-social da formação do indivíduo. Campinas-SP: Autores Associados, 1993. 227 p. 
DUARTE, N. Vigotski e o "aprender a aprender": crítica às apropriações neoliberais e pós-modernas da teoria vigotskiana. Campinas-SP: Autores Associados, 2004a.

DUARTE, N. Formação do indivíduo, consciência e alienação: $O$ ser humano na psicologia de A. N. Leontiev. Cad. Cedes, Campinas, v. 24, n. 62, p. 44-63, abr. 2004b. Disponível em <http://www.cedes.unicamp.br>. Acesso em: 6 ago. 2014.

DUARTE, N. As pedagogias do "aprender a aprender" e algumas ilusões da assim chamada sociedade do conhecimento. Rio de Janeiro: Revista Brasileira de Educação, n.18, p. 35-40, set/out/nov/dez, 2001. Disponível em < http://www.scielo.br/pdf/rbedu/n18/n18a04.pdf>. Acesso em: 16 jul. 2019.

EAGLETON, T. Marx estava certo. Trad. Regina Lyra. Rio de Janeiro: Nova Fronteira, 2012.

ELKONIN, D. Sobre el problema de la periodización del desarrollo psíquico en la infancia. In: DAVIDOV, V; SHUARE, M. (Org.). La psicología evolutiva y pedagógica en la URSS (antologia). Moscú: Editorial Progreso, 1987. p. 104-124.

FACCI, M. G. D. A periodização do desenvolvimento psicológico individual na perspectiva de Leontiev, Elkonin e Vigostski. Cad. Cedes, Campinas, v. 24, n. 62, p. 64-81, abr. 2004. Disponível em: <http://www.cedes.unicamp.br>. Acesso em: 14 jul. 2014.

FREIRE, P. Professora sim, tia não. São Paulo: Olho de Águia, 1993. 127p.

FREIRE, P. Educação "bancária" e educação libertadora. In: PATTO, Maria Helena Souza. Introdução à psicologia escolar. São Paulo: Casa do Psicólogo, 1997. p. 61 77.

FREIRE, S. B. A mediação do conhecimento teórico-filosófico na atividade pedagógica: um estudo sobre as possibilidades de superação das manifestações do fracasso escolar / Sandra Braga Freire; orientação Maria Eliza Mattosinho Bernardes. São Paulo: s. n., 2016. 183 p. ils.; anexos.

GADOTTI, Moacir. Concepção Dialética da Educação: Um Estudo Introdutório. São Paulo: Cortez: Autores Associados, 1983.

GRAMSCI, A. A concepção Dialética da História. Trad. Carlos Nelson Coutinho 2. ed. Rio de Janeiro: Civilização Brasileira, 1978. 341 p.

GRAMSCI, A. Os intelectuais e a Organização da Cultura - $3^{\text {a }}$ ed. - Rio de Janeiro: Civilização Brasileira, 1979.

GRAMSCI, A. Concepção Dialética da História. Rio de Janeiro: Civilização Brasileira, 1986.

GRAMSCI, A. Caderno 11 (1932-33): Introdução ao estudo da filosofia. In: Edição e tradução de Carlos Nelson Coutinho; coedição de Luiz Sérgio Henriques, Marco Aurélio Nogueira. Cadernos do cárcere: Introdução ao estudo da filosofia. Rio de Janeiro: Civilização Brasileira, 1999. v. I. 494 p.

GRAMSCI, A. Cadernos do cárcere, v. 2 - Antonio Gramsci: os intelectuais. O princípio educativo. Jornalismo. Ed. e trad. de Carlos N, Coutinho. Coed. de Luiz S. Henriques e Marco A. Nogueira. Rio de Janeiro: Civilização Brasileira, 2000a. 
GRAMSCI, A. Cadernos do cárcere, v. 3 - Antonio Gramsci: Maquiavel. Notas sobre o Estado e a política. Ed. e trad. de Carlos N. Coutinho. Coed. de Luiz S. Henriques e Marco A. Nogueira. Rio de Janeiro: Civilização Brasileira, 2000b.

GRAMSCI, A. Escritos políticos, v. 2. Org. e trad. de Carlos N. Coutinho. Rio de Janeiro: Civilização Brasileira, 2004.

GRAMSCI, A. Odeio os indiferentes: escritos de 1917. Trad. e aparato crítico de Daniela Mussi e Álvaro Bianchi - 1ª Ed. - São Paulo: Boitempo, 2020.

GRIMAL, P. Dicionário da mitologia grega e romana. 4 ed. Trad. Victor Jabouille. Rio de Janeiro: Bertrand Brasil, 2000.

GRUPPI, Luciano. Conceito de Hegemonia em Gramsci; tradução de Carlos Nelson Coutinho - Rio de Janeiro, Edições Graal, 1978.

HAMADA, I. A. O trabalho pedagógico e suas possibilidades enquanto práxis, no contexto da perspectiva crítica, histórica e cultural / Isabel Akemi Hamada; orientação Maria Eliza Mattozinho Bernardes. São Paulo: s. n., 2015. 108 p.

HELLER, A. Sociología de La vida cotidiana. Trad. Franscisco Yvars e Enric Pérez Nadal. Barcelona: Península, 1987.

HELLER, A. O cotidiano e a história. Trad. Carlos Nelson Coutinho e Leandro

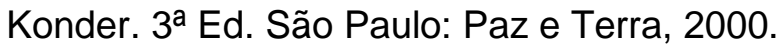

HOBSBAWN, E. Sobre a história. Trad. Cid Knipel Moreira. São Paulo: Companhia das Letras, 1998. $336 \mathrm{p}$.

KANT, Immanuel. Crítica da Razão Pura. 5 ${ }^{\text {a }}$ Edição. Trad.: Manuela Pinto e. Alexandre Morujão. Lisboa: Fundação Calouste Gulbenkian, 2001, 694 p.

KOSIK, K. Dialética do Concreto. Trad. de Célia Neves e Alderico Toríbio. Revisão de Célia Neves. Rio de Janeiro: Editora Paz e Terra, 1969, 230p.

LEONTIEV, A. Actividad, conciencia y personalidad. Cuba: Pueblo y Educación, 1983.

LEONTIEV, A. O desenvolvimento do psiquismo. Trad. Rubens Eduardo Frias. 2. ed. São Paulo: Centauro, 2004.

LIBÂNEO, J. C. Democratização da escola pública. A pedagogia crítico-social dos conteúdos. São Paulo. Edições Loyola, 1999.

MARTINS, L.M., and DUARTE, N., orgs. Formação de professores: limites contemporâneos e alternativas necessárias [online]. São Paulo: Editora UNESP; São Paulo: Cultura Acadêmica, 2010. 191 p.

MARX, K. Manuscritos econômico-filosóficos e outros textos escolhidos. 4. ed. Seleção de textos de José Arthur Gianotti, traduzido do alemão por José Carlos Bruni, José Arthur Gianotti e Edgard Malagodi. São Paulo: Nova Cultural, 1974. 413 p.

(Coleção Os Pensadores). 
MARX, K. O Capital: crítica da economia política. São Paulo, Abril Cultural, 1985.

MARX, K. Crítica à Filosofia do Direito de Hegel. Trad. Rubens Enderle. Leonardo de Deus. São Paulo: Boitempo, 2005.

MARX, K. A ideologia alemã. Trad. Luís Cláudio de Castro e Costa. São Paulo: Martins Fontes, 2007. 119 p.

MARX, K. Grundrisse: Manuscritos econômicos de 1857-1858: esboços da crítica da economia política. Tradução Mario Duayer, Nélio Schneider. São Paulo: Boitempo; Rio de Janeiro: Ed. UFRJ, 2011.

MIZUKAMI, M. das G. N. Ensino: as abordagens do processo. São Paulo, SP, Editora Pedagógica e Universitária Ltda, 1986. SILVA, N. R. da; MARTINS, S. T. F. Método histórico-social na psicologia social. Rio de Janeiro: Vozes, 2005. Cap. II, p. 25-51.

OLIVEIRA, S. L. de. Tratado de Metodologia Científica.São Paulo: Pioneira, 1997.

PARO, V. H. Parem de preparar para o trabalho!!! Reflexões acerca dos efeitos do neoliberalismo sobre a gestão e o papel da escola básica. In: FERRETTI, Celso João; SILVA JÚNIOR, João dos Reis; OLIVEIRA, Maria Rita N. (Org.). Trabalho, formação e currículo: para onde vai a escola? São Paulo: Xamã, 1999. p. 101-120.

PARO, V. H. A educação, a política e a administração: reflexões sobre a prática do diretor de escola. Educação e Pesquisa, São Paulo, v. 36, n. 3, p. 763-778, set./dez. 2010a.

PARO, V. H. Educação como exercício de poder: crítica ao senso comum em educação. 2. ed. São Paulo: Cortez, 2010b. 103 p.

PARO, V. H. Crítica da estrutura da escola. São Paulo: Cortez, 2011. 248 p.

PATTO, M. H. S. A produção do fracasso escolar: histórias de submissão e rebeldia. São Paulo: Casa do Psicólogo, 1990. 385 p.

PATTO, M. H. S. O papel social e a formação do psicólogo: contribuição para um debate necessário. In. PATTO, Maria Helena Souza (Org.). Introdução à psicologia escolar. São Paulo: Casa do Psicólogo, 1997. p. 459-468.

PORTELLI, H. Gramsci e o Bloco Histórico. Rio de Janeiro: Paz e Terra, 1977. 142p.

RICHARDSON, R. J. Pesquisa Social: Métodos e Técnicas. São Paulo: Atlas, 1999.

SÃO PAULO. Estado. Deliberação CEE n. 10/97: Fixa normas para elaboração do Regimento dos Estabelecimentos de Ensino Fundamental e Médio. Disponível em: <http://www.crmariocovas.sp.gov.br/pdf/diretrizes_p0830-0843_c.pdf>. Acesso em: 14 jan. 2019.

SÃO PAULO. Estado. Seduc-SP. Resolução SE n. 7, de 19 de janeiro de 1998: Estabelece diretrizes para a reorganização curricular dos cursos de ensino médio da rede estadual de ensino e dá providências correlatas. Disponível em: <http://www.crmariocovas.sp.gov.br/pdf/diretrizes_p1088-1093_c.pdf>. Acesso em: 14 jan. 2019. 
SÃO PAULO. Estado. Seduc-SP. Resolução SE n. 10, de 23 de janeiro de 1998: Inclui anexos III e IV na Resolução SE - 7, de 19-1-98. Disponível em:

<http://siau.edunet.sp.gov.br/ItemLise/arquivos/notas/10_98.htm?Time=12/21/2007\%2 011:42:33\%20PM>. Acesso em: 14 jan. 2019.

SÃO PAULO. Estado. Seduc-SP. Lei Complementar n. 444, de 27 de dezembro de 1985: Dispõe sobre o Estatuto do Magistério Paulista e dá providências correlatas. Disponível em:

<http://www.al.sp.gov.br/repositorio/legislacao/lei.complementar/1985/lei.complementa r-444-27.12.1985.html>. Acesso em: 20 jan. 2019.

SÃO PAULO. Estado. Seduc-SP. Lei Complementar n. 836, de 30 de dezembro de 1997: Institui Plano de Carreira, vencimentos e salários para os integrantes do Quadro do Magistério da Secretaria da Educação. Disponível em:

$<$ http://www.al.sp.gov.br/repositorio/legislacao/lei.complementar/1997/lei.complementa r-836-30.12.1997.html>. Acesso em: 14 jan. 2019.

SÃO PAULO. Estado. Seduc-SP. Currículo do Estado de São Paulo. 2012.

Disponível em: <http://www.educacao.sp.gov.br/curriculo>. Acesso em: 20 jan. 2019.

SÃO PAULO. Estado. Seduc-SP. Resolução SE 75, de 28 de novembro de 2013:

Dispõe sobre o processo anual de atribuição de classes e aulas ao pessoal docente do Quadro do Magistério. Disponível em:

<http://siau.edunet.sp.gov.br/ItemLise/arquivos/75_13.HTM?Time=28/09/2014\%2006:4 6:54>. Acesso em: 20 jan. 2019.

SÃO PAULO. Estado. Seduc-SP. Resolução SE 70, de 29 de dezembro de 2014: Altera dispositivos da Resolução SE 75, de 28-12- 2013, que dispõe sobre o processo anual de atribuição de classes e aulas. Disponível em:

<http://siau.edunet.sp.gov.br/ItemLise/arquivos/70_14.HTM?Time=20/01/2016\%2019:3 5:19>. Acesso em: 20 jan. 2019.

SÃO PAULO. Estado. Seduc-SP. Resolução SE 5, de 15 de janeiro de 2016: Altera a Resolução SE 75, de 28-11-2013, que dispõe sobre o processo anual de atribuição de classes e aulas ao pessoal docente do Quadro do Magistério. Disponível em:

<http://demogidascruzes.educacao.sp.gov.br/Paginas/Not\%C3\%ADcias/ResSE5-

2016.aspx>. Acesso em: 16 jan. 2019.

SÃO PAULO. Estado. Seduc-SP. Matriz de avaliação processual: filosofia e sociologia, ciências humanas; encarte do professor / Secretaria da Educação; coordenação, Ghisleine Trigo Silveira, Regina Aparecida Resek Santiago; elaboração, equipe curricular de Filosofia e de Sociologia. São Paulo: SE, 2016.

SÃO PAULO. Estado. Seduc-SP. Guia de transição. 2019. Disponível em: https://drive.google.com/drive/folders/1T9MkNoiqJCbF1ZioZUyQnsXYnpRr44-f. Acesso em: 01 de mai de 2019.

SÃO PAULO. Estado. Seduc-SP. Novo Ensino Médio. 2021. Disponível em: <https://novoensinomedio.educacao.sp.gov.br/>. Acesso em: 04 de out de 2021

SAVIANI, D. Educação: do senso comum à consciência filosófica. 3. ed. São Paulo: Autores Associados; Cortez, 1983. 224 p.

SAVIANI, D. Pedagogia histórico-crítica: primeiras aproximações. São Paulo: Autores Associados, 1991. $112 \mathrm{p}$. 
SAVIANI, D. Escola e democracia: teorias da educação, curvatura da vara, onze teses sobre educação e política. 36. ed. São Paulo: Autores Associados: Cortez, 2003.

SAVIANI. D. O conceito dialético de mediação na pedagogia histórico-crítica em intermediação com a psicologia histórico-cultural. Germinal: Marxismo e Educação em Debate, Salvador, v. 7, n. 1, p. 26-43, jun. 2015.

SAWAYA, S. M., Maria Helena Souza (orient). A leitura e a escrita como práticas culturais e o fracasso escolar das crianças de classes populares: uma contribuição crítica. São Paulo, 1999. 191 p.

SAWAYA, S. M. Novas perspectivas sobre o sucesso e o fracasso escolar. In: OLIVEIRA, Marta Kohl de; REGO, Teresa Cristina; SOUZA, Denise Trento R. (Orgs.). Psicologia, educação e as temáticas da vida contemporânea. São Paulo: Moderna, 2002. p. 197-213.

SAWAYA, S. M. Sociedad de la información, enseñanza y aprendizaje: la reforma educativa en Brasil. Universitas Psychologica [en linea] 2008. Disponível em: <http://www.autores.redalyc.org/articulo.oa?id=64770319> ISSN 1657-9267. Acesso em: 12 de jul. de 2018.

SFORNI, Marta S. de F.; GALUCH, Maria T. B. Conteúdos escolares e desenvolvimento humano: qual a unidade? Comunicações, Paraná, ano 13, n. 2, p. 150-158, 2006. Disponível em: <https://www.metodista.br/revistas/revistasunimep/index.php/comunicacao/article/view/946/454>. Acesso em: 13 jan. 2015.

SOUZA, M. P. R. de. Problemas de aprendizagem ou problemas de escolarização? Repensando o cotidiano escolar à luz da perspectiva histórico-crítica em psicologia. In: OLIVEIRA, Marta Kohl de; REGO, Teresa Cristina; SOUZA, Denise Trento R. (Orgs.). Psicologia, educação e as temáticas da vida contemporânea. São Paulo: Moderna, 2002. p. 177-195.

TOASSA, G. Emoções e vivências em Vigotski: investigação para uma perspectiva histórico-cultural / Gisele Toassa; orientadora Marilene Proença Rebello de Souza. São Paulo, 2009, 348 p.

VÁZQUEZ, A. S. Filosofia da práxis. 2. ed. Rio de Janeiro: Paz e Terra, 1977. 454 p.

VIGOTSKI, L. S. Sobre los sistemas psicológicos. In: Obras escogidas (Vol. 1, pp.7193). Madrid: Visor Distribuiciones (Trabalho original proferido em 1930), 1991.

VIGOTSKI, L. S. A construção do pensamento e da linguagem. São Paulo: Martins Fontes, 2000a. 496 p.

VIGOTSKI, L. S. Historia del desarrollo de las funciones psíquicas superiores. Obras Escogidas: Tomo III. Madrid: Visor, 2000b.

VIGOTSKI, L. S. Teoría de las emociones: estudio histórico-psicológico. Tradução: Judith Viaplana. Madrid: Akal, 2004a.

VIGOTSKI, L. S. Teoria e método em psicologia. São Paulo: Martins Fontes, 2004b.

VIGOTSKI, L. S. A formação social da mente: o desenvolvimento dos processos psicológicos superiores. 7. ed. São Paulo: Martins Fontes, 2007. 191 p. 
VIGOTSKI, L. S. Paidología del adolescente. In: Obras escogidas: Tomo IV, Madrid: Visor Distribuiciones, 2006. 


\section{APÊNDICE}

Anexo A - Reorganização do conteúdo do Currículo da Seduc-SP e de suas Situações de Aprendizagem Unidades Didáticas na (Re)Organização do Ensino

\begin{tabular}{|c|c|c|c|}
\hline Período de Intervenção & Conteúdo da Seduc-SP & Unidade Didática & Adequação Curricular \\
\hline Fevereiro - Abril & $\begin{array}{l}\text { Por que estudar Filosofia? } \\
\text { As áreas da Filosofia } \\
\text { Situação de Aprendizagem 1 - } \\
\text { Criando uma imagem crítica da } \\
\text { Filosofia } \\
\text { Habilidades: } \\
\text { 1. Dominar diferentes linguagens e } \\
\text { compreender diferentes fenômenos } \\
\text { do conhecimento. } \\
\text { 2. Reconhecer manifestações } \\
\text { histórico-sociais do pensamento. } \\
\text { 3. Selecionar, organizar e identificar } \\
\text { informações, bem como desenvolver } \\
\text { a capacidade de produção } \\
\text { de textos, associando quest.es atuais } \\
\text { a referências extraídas da História da } \\
\text { Filosofia. } \\
\text { Situação de Aprendizagem } 2 \text { - } \\
\text { Como funciona o intelecto? } \\
\text { Introdução ao empirismo e ao } \\
\text { criticismo } \\
\text { Habilidade: } \\
\text { 1. Organizar os argumentos de um } \\
\text { texto filosófico e associar quest.es } \\
\text { atuais a referências extraídas } \\
\text { da História da Filosofia. }\end{array}$ & $\begin{array}{l}\text { Introdução à Filosofia } \\
\\
\text { Objetivo: Apresentar a } \\
\text { história da Filosofia como } \\
\text { promotora } \\
\text { desenvolvimento } \\
\text { humano no homem. }\end{array}$ & $\begin{array}{l}\text { Conteúdo } \\
\text { A historicidade da Filosofia } \\
\text { Situação de Aprendizagem 1 - A história da } \\
\text { filosofia e sua conexão com o desenvolvimento } \\
\text { da humanidade } \\
\text { Situação de Aprendizagem 2- Das Cosmogonias } \\
\text { e Cosmologias à Racionalização do } \\
\text { Conhecimento sobre a origem do Universo e a } \\
\text { passagem dos pré-socráticos aos socráticos } \\
\text { Situação de Aprendizagem 3-O conceito de ética } \\
\text { e moral na filosofia antiga, medieval e moderna } \\
\text { Situação de Aprendizagem 4 - A Teoria do } \\
\text { Conhecimento no racionalismo, empirismo e } \\
\text { criticismo }\end{array}$ \\
\hline
\end{tabular}




\begin{tabular}{|c|c|c|c|}
\hline & $\begin{array}{l}\text { Situação de Aprendizagem } 3 \text { - } \\
\text { Instrumentos de pesquisa em } \\
\text { História da Filosofia } \\
\text { Habilidades: } \\
\text { 1. Compreensão e leitura de um texto } \\
\text { filosófico. } \\
\text { 2. Sistematização de ideias e sua } \\
\text { diferenciação. } \\
\text { Situação de Aprendizagem } 4 \text { - } \\
\text { Áreas da Filosofia } \\
\text { Habilidades: } \\
\text { 1. Selecionar, organizar, relacionar e } \\
\text { interpretar dados e informações, } \\
\text { representados de diferentes } \\
\text { formas. } \\
\text { 2. Identificar, em diferentes } \\
\text { manifestações ordenadas do } \\
\text { pensamento, questões filosóficas. } \\
\text { 3. Compreender as estruturas lógicas } \\
\text { do pensamento e descrever } \\
\text { sistematicamente as ações do } \\
\text { mundo circundante. }\end{array}$ & & \\
\hline Maio - Junho & $\begin{array}{l}\text { A Filosofia e as outras formas } \\
\text { de conhecimento: Mito, Cultura, } \\
\text { Religião } \\
\text { Situação de Aprendizagem } \mathbf{5}- \\
\text { Introdução à Filosofia da Ciência } \\
\text { Habilidades: } \\
\text { 1. Dominar diferentes linguagens e } \\
\text { compreender diferentes fenômenos } \\
\text { do conhecimento. }\end{array}$ & $\begin{array}{l}\text { Filosofia e Conhecimento } \\
\text { Objetivo: A constituição da } \\
\text { sociedade cultural, política } \\
\text { e da ciência por meio da } \\
\text { Filosofia. }\end{array}$ & $\begin{array}{l}\text { Conteúdo } \\
\text { O desenvolvimento das diversas formas de } \\
\text { conhecimento por meio da Filosofia } \\
\text { Situação de Aprendizagem } 5 \text { - O nascimento da } \\
\text { política por meio da Filosofia e como se dá a } \\
\text { participação política e a obrigatoriedade do voto } \\
\text { no Brasil }\end{array}$ \\
\hline
\end{tabular}


2. Desenvolver uma visão crítica da Ciência.

3. Reconhecer a Ciência como atividade humana.

4. Sistematizar conceitos, informaç.es e fundamentar conhecimentos teóricos.

Situação de Aprendizagem 6 Introdução à Filosofia da Religião Deus e a Razão

Habilidades:

1. Desenvolver noções sobre os limites da racionalidade.

2. Dialogar com base nas quest.es de alteridade.

Situacão de Aprendizagem 7 Introdução à Filosofia da Cultura Mito e Cultura

Habilidades:

1. Refletir sobre a práxis da alteridade.

2. Reconhecer o aspecto simbólico do homem e os compromissos de cidadania e respeito à diferença.

Situação de Aprendizagem 8 Introdução à Filosofia da Arte Nietzsche

Habilidades:

1. Reconhecer a condição estética e existencial do homem.
Situação de Aprendizagem 6 - A história da ciência e a contribuição da Filosofia para o seu desenvolvimento e a ética na ciência e nos processos de medicalização

Situação de Aprendizagem 7 - Deus e a Razão: 0 sobrenatural, as crenças e o que a ciência diz a respeito da espiritualidade

Situação de Aprendizagem 8 -A presença da Filosofia na Arte: o pensamento filosófico e estético e a Filosofia como expressão artística 


\begin{tabular}{|c|c|c|c|}
\hline & $\begin{array}{l}\text { 2. Relacionar o sentido do belo à } \\
\text { compreensão da vida e da cultura, } \\
\text { em sentido amplo. }\end{array}$ & & \\
\hline Agosto - Setembro & 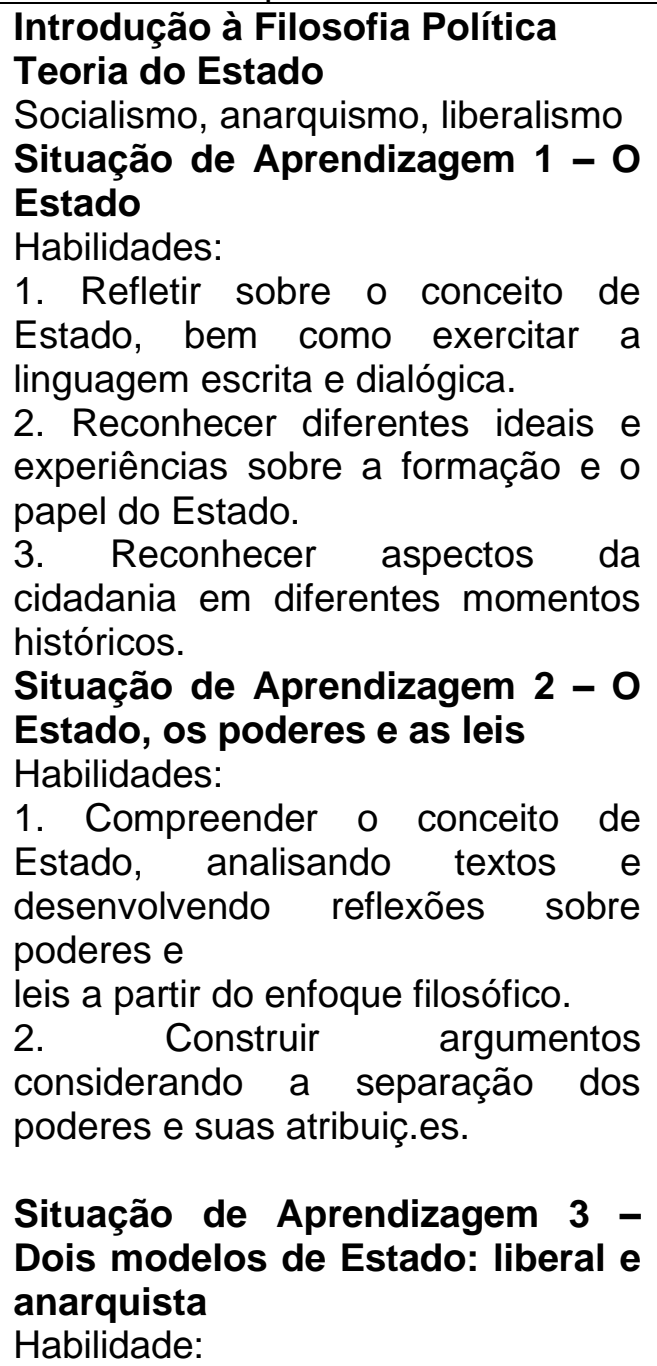 & $\begin{array}{l}\text { Filosofia é política } \\
\text { Objetivo: Apresentar a } \\
\text { política como } \\
\text { manifestação de um } \\
\text { contexto social e do } \\
\begin{array}{l}\text { pensamento filosófico no } \\
\text { decurso da história }\end{array}\end{array}$ & $\begin{array}{l}\text { Conteúdo central } \\
\text { Os movimentos políticos dados por meio da } \\
\text { Filosofia } \\
\text { Situação de Aprendizagem } 1 \text { - As teorias político- } \\
\text { filosóficas e suas contribuições para a } \\
\text { constituição da sociedade atual } \\
\text { Situação de Aprendizagem } 2 \text { - A Filosofia como } \\
\text { instrumento de empoderamento para } \\
\text { compreensão da organização do Estado, das leis } \\
\text { e dos direitos } \\
\text { Situação de Aprendizagem } 3 \text { - A concepção } \\
\text { dialética marxista para compreensão da } \\
\text { sociedade no decurso de sua história } \\
\text { Situação de Aprendizagem } 4 \text { - Capitalismo, } \\
\text { Anarquismo, Comunismo e Socialismo: a } \\
\text { expressão da teoria na práxis }\end{array}$ \\
\hline
\end{tabular}




\begin{tabular}{|c|c|c|c|}
\hline & $\begin{array}{l}\text { 1. Refletir sobre a relação entre } \\
\text { Estado e sociedade. } \\
\text { Situação de Aprendizagem } 4 \text { - } \\
\text { Capitalismo segundo Marx } \\
\text { Habilidades: } \\
\text { 1. Relacionar informaç.es } \\
\text { representadas de diferentes formas e } \\
\text { conhecimentos disponíveis em } \\
\text { diferentes situaç.es para construir } \\
\text { argumentação consistente. } \\
2 \text { Compreender a lógica de } \\
\text { funcionamento da sociedade } \\
\text { capitalista, refletindo criticamente } \\
\text { sobre modo de produção à luz de } \\
\text { esse modo } \\
\text { algumas categorias segundo Marx. } \\
\text { 3. Apropriar-se crítica } \\
\text { rigorosamente do conteúdo estudado } \\
\text { (Estado), fazendo dele instrumento } \\
\text { para a reflexão sobre a própria } \\
\text { realidade. }\end{array}$ & & \\
\hline Outubro - Novembro & $\begin{array}{l}\text { Filosofia Política } \\
\text { - Democracia e cidadania: } \\
\text { origens, conceitos e dilemas } \\
\text { - Desigualdade social e } \\
\text { ideológica } \\
\text { - Democracia e justiça social } \\
\text { - Os direitos humanos } \\
\text { - Participação política } \\
\text { Situação de Aprendizagem } \mathbf{5}- \\
\text { Desigualdade social e ideologia } \\
\text { Habilidades: }\end{array}$ & $\begin{array}{l}\text { A Filosofia como } \\
\text { expressão do humano do } \\
\text { homem } \\
\text { Objetivo: Analisar como a } \\
\text { Filosofia produtora da } \\
\text { cultura elaborada socio- } \\
\text { historicamente e suas } \\
\text { intervenções na história da } \\
\text { humanidade. }\end{array}$ & 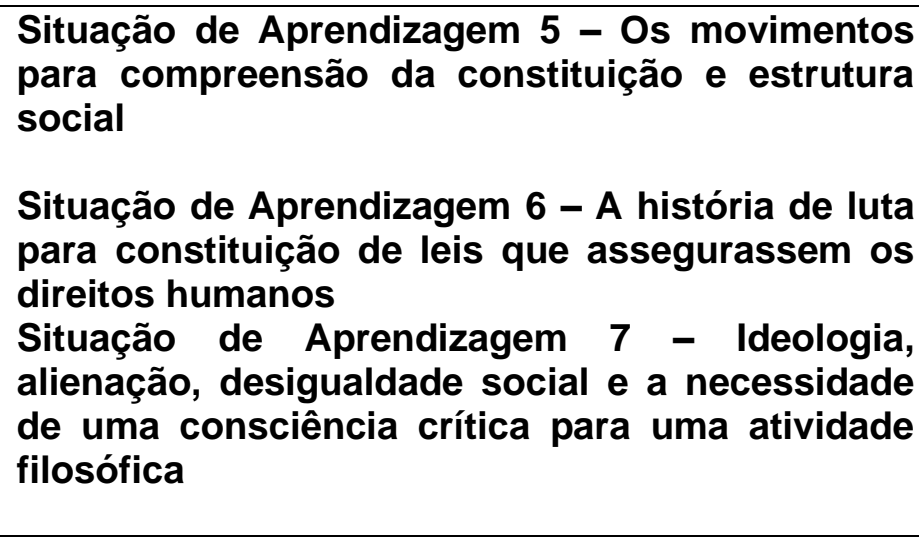 \\
\hline
\end{tabular}




\begin{tabular}{|c|c|}
\hline $\begin{array}{l}\text { 1. Refletir criticamente sobre os } \\
\text { fatores considerados relevantes para } \\
\text { o desenvolvimento integral do } \\
\text { ser humano. } \\
\text { 2. Compreender o conceito de } \\
\text { ideologia a partir da concepção de } \\
\text { Karl Marx e Friedrich Engels. } \\
\text { Situação de Aprendizagem } 6 \text { - } \\
\text { Democracia e justiça social } \\
\text { Habilidade: } \\
\text { 1. Refletir sobre a democracia a partir } \\
\text { da perspectiva de igualdade entre os } \\
\text { homens. } \\
\text { Situação de Aprendizagem } 7 \text { - Os } \\
\text { Direitos Humanos } \\
\text { Habilidade: } \\
\text { 1. Reconhecer a influência do } \\
\text { movimento iluminista na Declaração } \\
\text { dos Direitos Humanos. } \\
\text { Situação de Aprendizagem } 8 \text { - } \\
\text { Participação política } \\
\text { Habilidade: } \\
\text { 1. Compreender e vivenciar uma } \\
\text { experiência política com as } \\
\text { autoridades locais, eleitas } \\
\text { democraticamente. }\end{array}$ & $\begin{array}{l}\text { Situação de Aprendizagem } 8 \text { - Os movimentos de } \\
\text { luta contra a expropriação social }\end{array}$ \\
\hline
\end{tabular}

